UNIVERSIDAD AUTÓNOMA METROPOLITANA

UNIDAD IZTAPALAPA

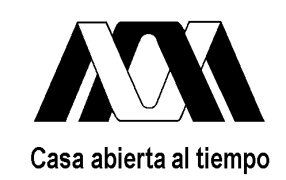

EVALUACIÓN DE LA ACTIVIDAD PREBIÓTICA DE HIDROLIZADOS DEL MATERIAL LIGNOCELULÓSICO DE LA PLANTA DE AMARANTO

(Amaranthus hypochondriacus L.).

T E S I S

PARA OBTENER EL GRADO DE

MAESTRÍA EN BIOTECNOLOGÍA

PRESENTA:

QA. Alex María Daniela Flores Calderón

Director:

Dr. Jorge Soriano Santos

México D.F. Agosto de 2013. 
"La maestría en Biotecnología de la Universidad Autónoma Metropolitana está incluida en el Padrón Nacional de Posgrados de Calidad (PNC), con la referencia 001465"

Este trabajo contó con el apoyo del CONACYT a través de la beca 226023 
México D.F., 19 de agosto del 2013.

El jurado designado por la División de ciencias Biológicas y de la Salud de la Unidad Iztapalapa, aprobó la tesis:

\section{EVALUACIÓN DE LA ACTIVIDAD PREBIÓTICA DE HIDROLIZADOS DEL MATERIAL LIGNOCELULÓSICO DE LA PLANTA DE AMARANTO (Amaranthus hypochondriacus L.).}

Que presenta:

QA. Alex María Daniela Flores Calderón

Comité tutorial:

Director: Dr. Jorge Soriano Santos

Asesor: Dr. José Ramón Verde Calvo

Asesor: Dr. Ezequiel Delgado Fornué

Jurado:

Presidente: Dr. José Ramón Verde Calvo

Secretario: Dr. Héctor Bernardo Escalona Buendía

Vocal: Dr. Marcos Meneses Mayo

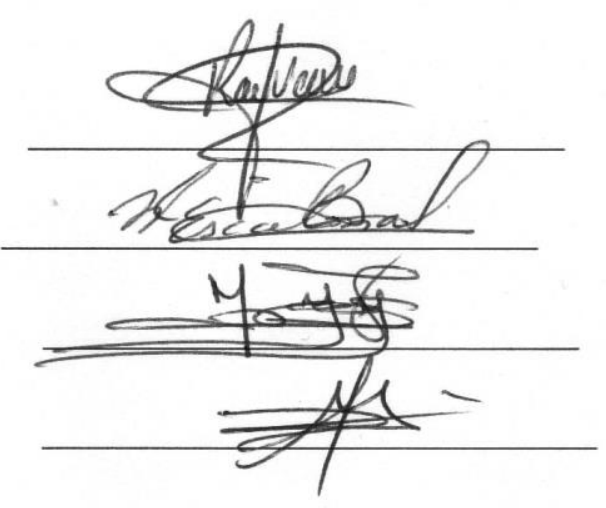

Vocal: Dr. Gerardo Díaz Godínez 


\section{AGRADECIMIENTOS}

Al Dr. Jorge Soriano Santos por haberme permitido trabajar en este proyecto y por su apoyo incondicional para el buen desarrollo del mismo.

Al Dr. José Ramón Verde Calvo por su asesoría en la parte experimental de cromatografía, al Dr. Héctor Bernardo Escalona Buendía por el apoyo otorgado en la parte estadística y al Dr. Gerardo Díaz Godínez por su asesoría en la parte de microbiología.

A Dios por mostrarme su amor infinito a través de la familia, las enseñanzas y las oportunidades que me ha dado. A mi Madre por ser mi inspiración e inyectarme de fortaleza. A mis hermanos Ramón, Lidia, Cristina y Emmanuel por ser mi ejemplo y motivación, a mis sobrinos Alelí y Uriel que a través de una sonrisa muestran la existencia de cosas maravillosas. Y a mi esposo por todo su apoyo, en este proyecto tan importante de mi vida. Familia, los amo.

A mis amigos Frida, Majo, Edgar y Belem, gracias por todos sus consejos y buenos momentos. 


\section{RESUMEN}

De la producción del cultivo de amaranto se obtiene cantidades considerables de residuos agrícolas llamados rastrojos, a pesar de que son potencialmente aptos para ser utilizados como materia prima en la producción de alimento para ganado, biomasa microbiana, etc., a través del proceso de hidrólisis de los hidratos de carbono que ellos contienen, este material está siendo subutilizado en nuestro país causando serios problemas de contaminación ambiental, cuando es quemado a cielo abierto. Debido a su naturaleza, el rastrojo de amaranto es fuente importante de material lignocelulósico, que está constituido por lignina, celulosa y hemicelulosa. Estudios realizados por Arce (2011), mostraron que el contenido en base seca de fibra insoluble en el tallo de la planta de amaranto es de $40.5 \mathrm{~g}$ por $100 \mathrm{~g}$ de este rastrojo, e incluye un contenido de hemicelulosa y pentosanos de $14.6 \mathrm{y}$ $16.1 \mathrm{~g}$. De acuerdo con lo anterior, el objetivo de este trabajo fue solubilizar la fibra de la planta de amaranto, para obtener un compuesto prebiótico. Para alcanzar este objetivo se utilizó una muestra de la planta de amaranto que fue el tallo y se sometió a hidrólisis ácida para liberar a partir de la hemicelulosa el xilano, polímero que al ser hidrolizado forma xilooligosacáridos constituidos de unidades de xilosa unidas por enlaces $\beta 1-4$, y de los cuales se ha reportado que tienen actividad prebiótica. Se realizaron dos experimentos de hidrólisis ácida con ácido sulfúrico, en el primer experimento se evaluaron las concentraciones de ácido de $2.5,3.5$ y $5.0 \% \mathrm{~m} / \mathrm{v}$ a una temperatura constante de $121{ }^{\circ} \mathrm{C}$ para obtener cinéticas de hidrólisis a los tiempos de 30, 60 y 90 min, la producción de azúcares reductores totales fue de $41 \pm 1.8$ a $72 \pm 1.4 \mathrm{mg}$ xilosa por g de tallo. Del primer experimento se eligió la concentración de ácido que permitió observar la cinética de hidrólisis más corta y que correspondió a la concentración de $5.0 \% \mathrm{~m} / \mathrm{v}$, por lo que para realizar el segundo experimento se obtuvieron hidrolizados a esta concentración de ácido y se evaluaron las temperaturas de 90 y $100{ }^{\circ} \mathrm{C}$ durante los tiempos de 30, 60, 90, 120 y 150 min, para las muestras obtenidas a $90{ }^{\circ} \mathrm{C}$ se obtuvieron porcentajes de azúcares reductores totales entre $64 \pm 1.0$ y $81 \pm 2.3$, para los hidrolizados de $100{ }^{\circ} \mathrm{C}$ de $52 \pm 1.3$ a $92 \pm 3.2$, mostrando una alta posibilidad que en ninguna de las muestras se degradaran sus azúcares monoméricos a furfural o hidroximetilfurfural. Los hidrolizados obtenidos del segundo experimento fueron liofilizados y utilizados como fuente de carbono para bacterias colónicas en la fermentación in vitro. Los resultados mostraron cinéticas de crecimiento con fases de adaptación muy cortas, prácticamente imperceptibles, la fase exponencial fue 
menor a $8 \mathrm{~h}$ en general para todos los hidrolizados obtenidos a las diferentes combinaciones de temperatura y tiempo. La velocidad específica de crecimiento para las bacterias colónicas en los hidrolizados osciló entre $0.12 \pm 0.01$ y $0.37 \pm 0.03 \mathrm{~h}^{-1}$, las menores velocidades se observaron en ambas temperaturas a los tiempos más cortos (30 min), de acuerdo con estas velocidades, los tiempos de duplicación se encontraron en un rango de 5.8 a $2 \mathrm{~h}$, los controles inulina y pectina presentaron parámetros cinéticos de 0.43 \pm 0.04 y $0.24 \pm 0.02 \mathrm{~h}^{-1}$, así como tiempos de duplicación de 1.6 y 1.9 h respectivamente, similares a los hidrolizados y que dependiendo de la muestra presentaron o no diferencia significativa. El consumo de hidratos de carbono presentes en el medio de cultivo a partir de los hidrolizados se encontró en el rango de $66.6 \% \pm 1.4$ (obtenido a $100{ }^{\circ} \mathrm{C}-30 \mathrm{~min}$ ) a $85 \% \pm 4.0\left(90{ }^{\circ} \mathrm{C}-90 \mathrm{~min}\right)$, solo el menor porcentaje fue significativamente inferior a los controles inulina de $96.4 \pm 1.0$ y pectina $92.8 \pm 0.2$. El rendimiento biomasa sustrato para las fermentaciones de los hidrolizados se encontró entre $0.32 \mathrm{~kg}$ biomasa $/ \mathrm{kg}$ hidratos de carbono $\pm 0.08\left(90^{\circ} \mathrm{C}-90 \mathrm{~min}\right)$ y $0.68 \mathrm{~kg}$ biomasa $/ \mathrm{kg}$ hidratos de carbono $\pm 0.09\left(100{ }^{\circ} \mathrm{C}-\right.$ $60 \mathrm{~min}$ ), siendo este segundo rendimiento significativamente mayor al de los controles $(0.28 \pm 0.01,0.24 \pm 0.07$, inulina y pectina, respectivamente). Los cambios de $\mathrm{pH}$ durante la fermentación de los hidrolizados obtenidos a $90{ }^{\circ} \mathrm{C}$ fueron inferiores a los observados $100{ }^{\circ} \mathrm{C}$, en cada caso el descenso de las 0 a las 24 horas fue de 6.8 a 6.2 y de 6.8 a 5.8 respectivamente. Los cambios de $\mathrm{pH}$ de los hidrolizados de $100{ }^{\circ} \mathrm{C}$ fueron similares a la inulina (6.6 - 5.9) y a la pectina (6.6 - 5.7). La concentración de los ácidos grasos de cadena corta (AGCC) osciló entre $8.3 \pm 0.5$ y $28 \pm 1.4 \mathrm{mmol} / \mathrm{L}$ y es significativamente inferior a la obtenida por la inulina $(10.1 \pm 0.2-29.3 \pm 0.3 \mathrm{mmol} / \mathrm{L})$ y pectina $(12.3 \pm 0.3-$ $35.2 \pm 0.4 \mathrm{mmol} / \mathrm{L}$ ). Debido a que el hidrolizado obtenido a $100{ }^{\circ} \mathrm{C}$ por $60 \mathrm{~min}$ dio la producción de AGCC más alta, se determinó elegir estas condiciones de temperatura y tiempo para obtener a partir de este hidrolizado los oligosacáridos.

A partir de los datos de la fermentación in vitro de los oligosacáridos se obtuvieron cinéticas de crecimiento de las bacterias colónicas similares a los controles, con fase exponencial inferior a seis horas. La velocidad específica de crecimiento de las bacterias colónicas al metabolizar los oligosacáridos fue de $0.36 \mathrm{~h}^{-1} \pm 0.04$, que no es significativamente diferente a las velocidades del hidrolizado $\left(0.35 \mathrm{~h}^{-1} \pm 0.02\right)$ sin purificar y de los controles (inulina $0.43 \mathrm{~h}^{-1} \pm 0.04 \mathrm{y}$ pectina $0.24 \mathrm{~h}^{-1} \pm 0.02$ ). El porcentaje de consumo de los oligosacáridos $(92.2 \% \pm 0.3)$ fue superior al hidrolizado $(76.3 \% \pm 1.0)$ y 
respecto a la pectina $(92.8 \% \pm 0.2)$ no fue significativamente diferente, mientras que la inulina $(96.4 \% \pm 1.0)$ si mostro un consumo significativamente mayor. El rendimiento biomasa-sustrato $(\mathrm{Yx} / \mathrm{s})$ observado en la fermentación de los oligosacáridos $(0.34 \pm 0.1)$, no fue significativamente diferente al obtenido con los controles $(0.28 \pm 0.01,0.24 \pm 0.07$, inulina y pectina respectivamente). El Yx/s del hidrolizado fue significativamente superior a las muestras mencionadas. El cambio de pH de los oligosacáridos fue bajo, sin embargo las cantidades de ácidos grasos de cadena corta, a los tiempos de 6 y 10 h (11.4 y 31.2 $\mathrm{mmol} / \mathrm{L}$ respectivamente) fueron significativamente superiores a la inulina (10.1 y 29.3 mmol/L) e inferiores a la pectina $(12.3$ y $35.2 \mathrm{mmol} / \mathrm{L})$. Con la producción de ácidos grasos de cadena corta se pudo observar que los hidrolizados obtenidos a partir del tallo de amaranto tienen actividad prebiótica.

Al desarrollar este proyecto se obtuvo una fibra soluble a partir de residuos de la planta de amaranto que es capaz de promover el crecimiento de bacterias colónicas, beneficio que de llevarse a la práctica después de evaluar su capacidad prebiótica mediante estudios en animales, permitirá ofrecer al mercado de alimentos un producto atractivo por su impacto positivo a la salud, además de reducir problemas de contaminación. 


\section{ABSTRACT}

Crop production amaranth obtained considerable quantities of residues known agricultural waste, although they are potentially suitable for use as raw material in the production of livestock feed, microbial biomass, etc.. Through hydrolysis process of carbohydrates they contain, this material is being underutilized in our country causing serious environmental pollution problems, when it is burned in the open. Due to their nature, Amaranth stover source of lignocellulosic material, which consists of lignin, cellulose and hemicellulose. Studies by Arce (2011), showed that on a dry basis content of insoluble fiber in the stem of the amaranth plant is $40.5 \mathrm{~g}$ per $100 \mathrm{~g}$ of the stubble, and includes a pentosan and hemicellulose content of 14.6 and $16.1 \mathrm{~g}$. Accordingly, the objective of this work was to solubilize plant fiber amaranth, to obtain a prebiotic compound. To achieve this objective we used a sample of the amaranth plant stem and which was subjected to acid hydrolysis to liberate from the hemicellulose xylan, to be hydrolysed polymer form consisting of xylooligosaccharides xylose units linked by $\beta 1$ -4 , and which are reported to have prebiotic activity. Two experiments were performed by acid hydrolysis with sulfuric acid, in the first experiment acid concentrations of 2.5 , 3.5 and $5.0 \% \mathrm{~m} / \mathrm{v}$ at a constant temperature of $121{ }^{\circ} \mathrm{C}$ for hydrolysis kinetics to the times 30, 60 and $90 \mathrm{~min}$, the production of total reducing sugars was $41 \pm 1.8$ to $72 \pm$ $1.4 \mathrm{mg}$ per $\mathrm{g}$ xylose stem. The first experiment was chosen acid concentration observed kinetics allowing shorter hydrolysis and which corresponded to the concentration of 5.0 $\% \mathrm{~m} / \mathrm{v}$, so to make the second experiment were hydrolyzed to this acid concentration and assessed temperatures of 90 and $100{ }^{\circ} \mathrm{C}$ for times 30, 60, 90, 120 and $150 \mathrm{~min}$ for the samples obtained at $90{ }^{\circ} \mathrm{C}$ were obtained percentages total reducing sugars from 64 \pm 1.0 and $81 \pm 2.3$, hydrolysates $100{ }^{\circ} \mathrm{C} 52 \pm 1.3-92 \pm 3.2$, showing a high possibility that none of the samples to degrade their monomeric sugars or hydroxymethyl furfural. The hydrolysates obtained by hydrolysis of the second experiment were lyophilized and used as a carbon source for colonic bacteria in vitro fermentation. The results showed growth kinetics very short adaptation phase, virtually imperceptible, the exponential phase was less than $8 \mathrm{~h}$ generally hydrolysates obtained for all the different combinations of temperature and time. The specific growth rate for colonic bacteria in the hydrolysates ranged from $0.12 \pm 0.01$ and $0.37 \pm 0.03 \mathrm{~h}^{-1}$, the lower speeds were observed at both temperatures shorter times $(30 \mathrm{~min})$, according to these speeds, Doubling times were in a range of 5.8 to $2 \mathrm{~h}$, inulin and pectin controls showed kinetic 
parameters of $0.43 \pm 0.04$ and $0.24 \pm 0.02 \mathrm{~h}^{-1}$, and doubling times of 1.6 and $1.9 \mathrm{~h}$ respectively similar to those hydrolysed and depending on whether or not the sample had significant difference. Consumption of carbohydrates present in the culture medium from hydrolysates found in the range of $66.6 \% \pm 1.4$ (obtained at $100{ }^{\circ} \mathrm{C}-30 \mathrm{~min}$ ) $85 \%$ $\pm 4.0\left(90{ }^{\circ} \mathrm{C}-90 \mathrm{~min}\right)$, single the lowest percentage was significantly lower than inulin controls $96.4 \pm 1.0$ and $92.8 \pm 0.2$ pectin. Yield biomass substrate for fermentations hydrolysates was between $0.32 \mathrm{~kg}$ biomass $/ \mathrm{kg}$ carbohydrates $\pm 0.08\left(90{ }^{\circ} \mathrm{C}-90 \mathrm{~min}\right)$ and $0.68 \mathrm{~kg}$ biomass $/ \mathrm{kg}$ carbohydrates $\pm 0.09\left(100{ }^{\circ} \mathrm{C}-60 \mathrm{~min}\right)$, being this second performance significantly higher than in controls $(0.28 \pm 0.01,0.24 \pm 0.07$, inulin and pectin, respectively). $\mathrm{pH}$ changes during the fermentation of the hydrolysates obtained at $90{ }^{\circ} \mathrm{C}$ were lower than $100{ }^{\circ} \mathrm{C}$ observed in each case the decline of 0 to 24 hours was from 6.8 to 6.2 and 6.8 to 5.8 respectively. $\mathrm{PH}$ changes of the hydrolysates of $100{ }^{\circ} \mathrm{C}$ were similar to inulin (6.6 - 5.9) and pectin (6.6 - 5.7). SCFA concentration ranged from $8.3 \pm 0.5$ and $28 \pm 1.4 \mathrm{mmol} / \mathrm{L}$ and is significantly lower than that obtained by inulin $(10.1 \pm 0.2-29.3 \pm 0.3 \mathrm{mmol} / \mathrm{L})$ and pectin $(12.3 \pm 0.3-35.2 \pm 0.4 \mathrm{mmol} / \mathrm{L})$. Because the hydrolysate obtained at $100{ }^{\circ} \mathrm{C}$ for $60 \mathrm{~min}$ gave the highest SCFA production was determined to choose those conditions of temperature and time for this hydrolysate from oligosaccharides.

From the data in the in vitro fermentation of the oligosaccharides were obtained from growth kinetics colonic bacteria similar to controls, with exponential phase of less than six hours. The specific growth rate of colonic bacteria to metabolize oligosaccharides were $0.36 \pm 0.04 \mathrm{~h}^{-1}$, which is not significantly different speeds hydrolysate $(0.35 \pm 0.02$ $\mathrm{h}^{-1}$ ) without purification and controls (inulin $0.43 \mathrm{~h}^{-1} \pm 0.04$ and pectin $0.24 \pm 0.02 \mathrm{~h}^{-1}$ ). The consumption percentage of oligosaccharides $(92.2 \% \pm 0.3)$ was higher than hydrolysate $(76.3 \% \pm 1.0)$ and compared to the pectin $(92.8 \% \pm 0.2)$ was not significantly different, whereas inulin $(96.4 \% \pm 1.0)$ if showed significantly higher consumption. Biomass yield-substrate $(\mathrm{Yx} / \mathrm{s})$ shown in the fermentation of the oligosaccharides $(0.34 \pm 0.1)$ was not significantly different from that obtained with controls $(0.28 \pm 0.01,0.24 \pm 0.07$, inulin and pectin respectively). The $\mathrm{Yx} / \mathrm{s}$ of the hydrolysate was significantly higher than the samples mentioned. The change in $\mathrm{pH}$ of the oligosaccharides was very low, however the amounts of short chain fatty acids at times of 6 and $10 \mathrm{~h}(11.4$ and $31.2 \mathrm{mmol} / \mathrm{L}$, respectively) were significantly higher than the inulin $(10.1$ and $29.3 \mathrm{mmol} / \mathrm{L})$ and lower than the pectin $(12.3$ and $35.2 \mathrm{mmol} / \mathrm{L})$. 
With the production of short chain fatty acids could be seen that the hydrolysates obtained from the stem of amaranth have prebiotic activity.

In developing this project obtained a soluble fiber from waste amaranth plant that is capable of promoting the growth of colonic bacteria, benefit to be implemented after evaluating prebiotic capacity by animal studies, will provide the market an attractive food for its positive impact on health and reduce pollution problems. 


\section{CONTENIDO}

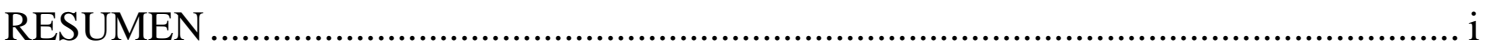

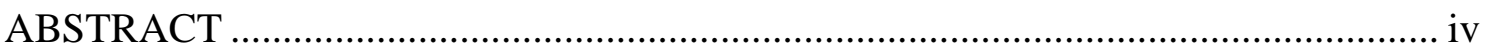

ÍNDICE DE TABLAS ................................................................................... ix

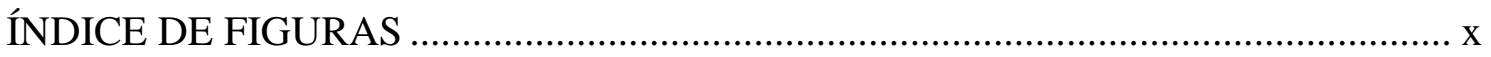

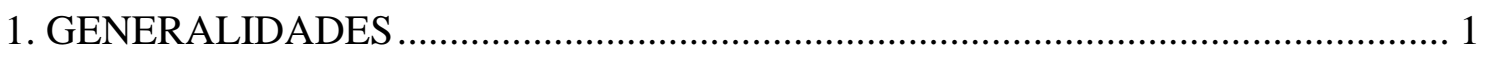

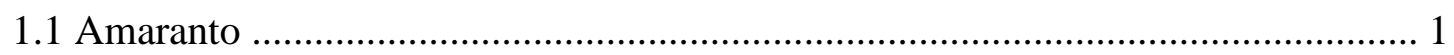

1.2 Material lignocelulósico del rastrojo de amaranto .................................................. 3

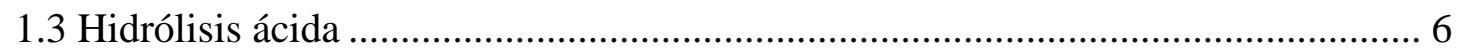

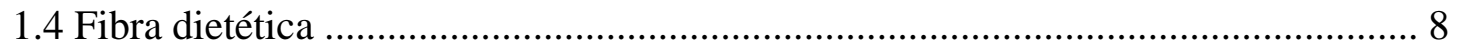

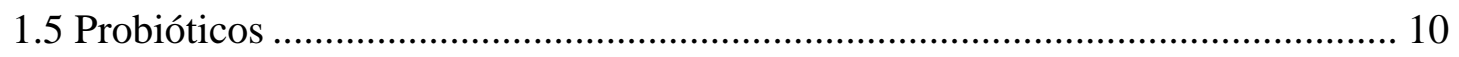

1.5.1 Metabolismo en el colón .................................................................... 12

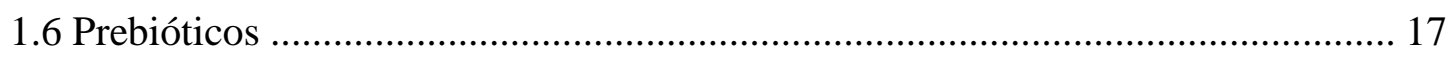

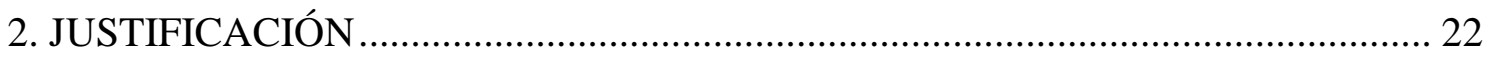

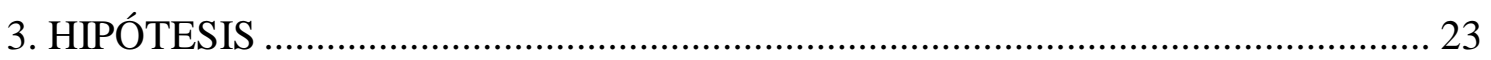

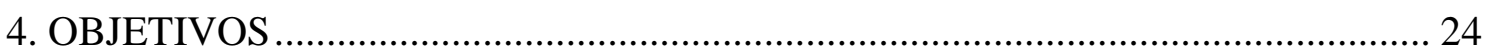

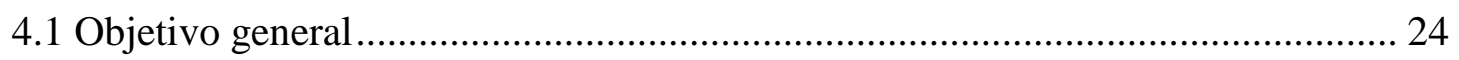

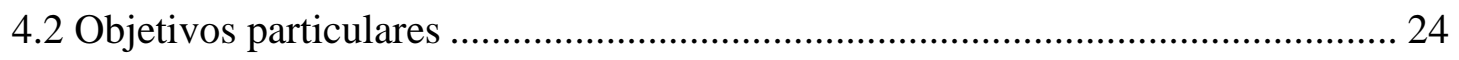

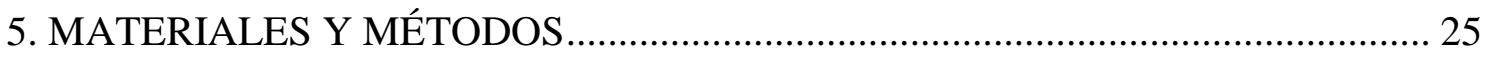

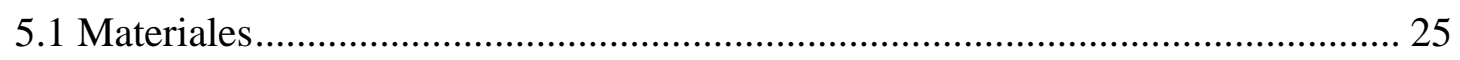

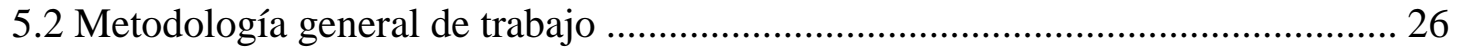

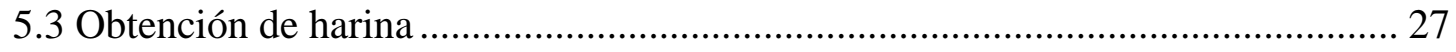

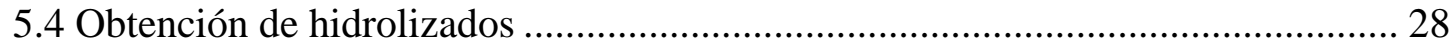

5.4.1 Hidrólisis ácida primer experimento ....................................................... 28

5.4.1.1 Cuantificación de azúcares reductores.............................28

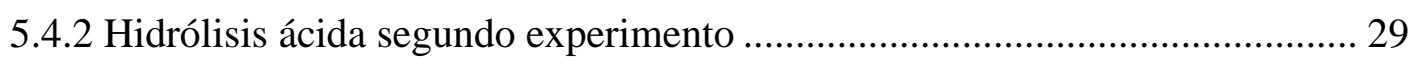


5.4.2.1 Cuantificación de hidratos de carbono

totales .289

5.5 Evaluación de la actividad prebiótica ............................................................... 30

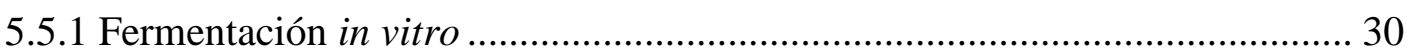

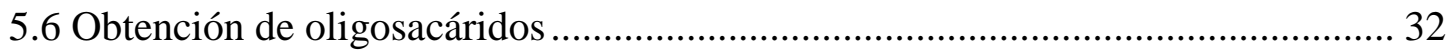

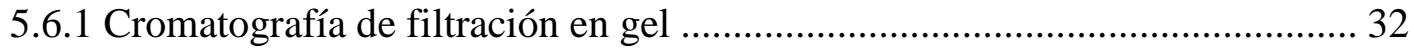

5.7 Diseño experimental y análisis estadístico .......................................................... 33

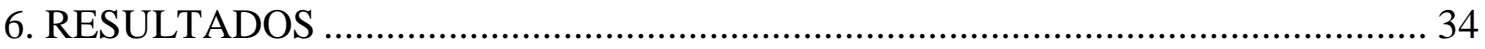

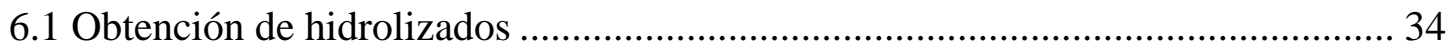

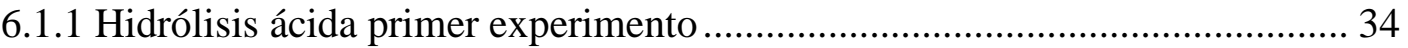

6.1.2 Hidrólisis ácida segundo experimento ......................................................... 35

6.2 Evaluación de la actividad prebiótica. Fermentación in vitro ................................ 36

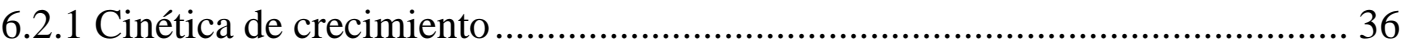

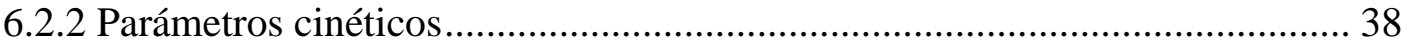

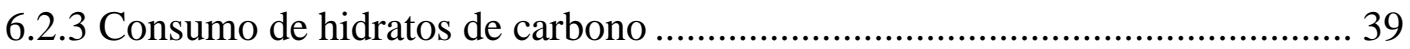

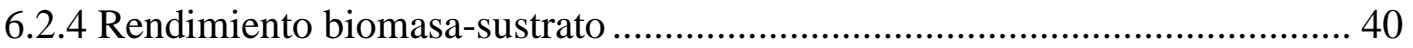

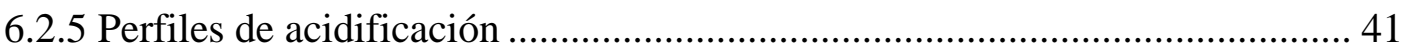

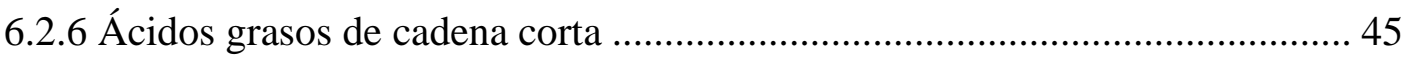

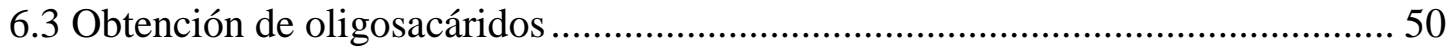

6.4 Evaluación de actividad prebiótica de los oligosacáridos. Fermentación in vitro. 51

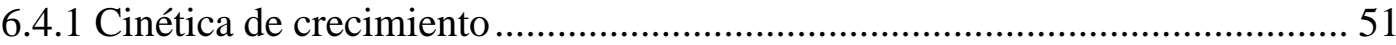

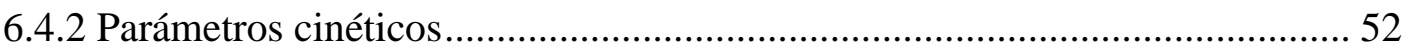

6.4.3 Consumo de hidratos de carbono y rendimiento biomasa-sustrato................ 53

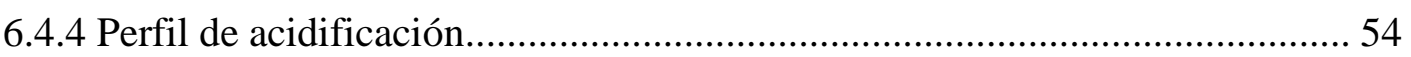

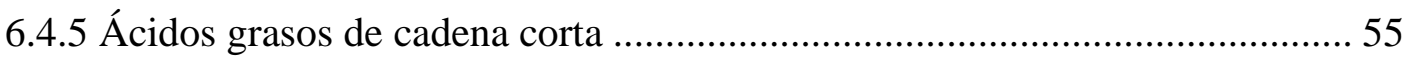

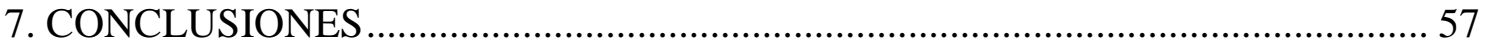

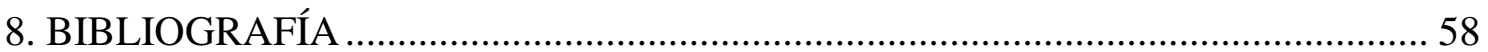

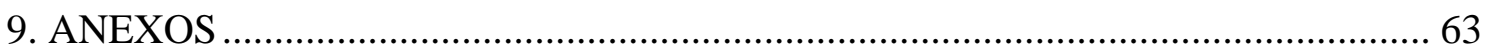




\section{ÍNDICE DE TABLAS}

1. Principales estados productores de amaranto en el país ............................................ 2

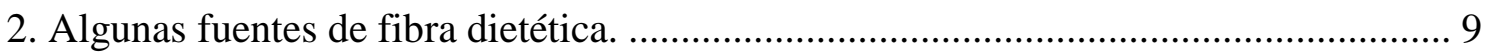

3. Especies microbianas cuyas cepas tienen aplicación como probióticos..................... 11

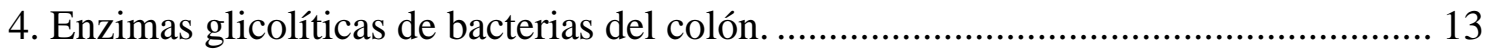

5. Clasificación de los compuestos prebióticos con base a su origen.................17

6. Contenido de hidratos de carbono totales, azúcares reductores totales de las muestras obtenidos en el segundo experimento de hidrólisis ácida. .......................................... 35

7. Velocidad específica de crecimiento $(\mu)$ y tiempo de duplicación (td) de las bacterias colónicas en la fermentación de los hidrolizados.......................................................... 38

8. Consumo de hidratos de carbono (\%) por las bacterias colónicas durante la

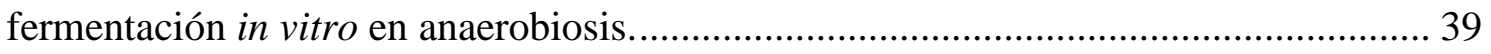

9. Rendimientos biomasa-sustrato ( $\mathrm{Yx} / \mathrm{s}$ ) para las cinéticas de crecimiento de los

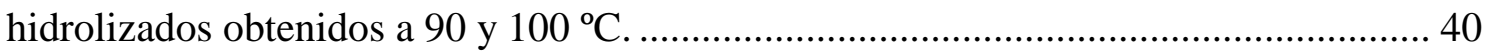

10. Velocidad específica de crecimiento y tiempo de duplicación de los oligosacáridos, del hidrolizado y de los controles.

11. Consumo de hidratos de carbono y rendimiento biomasa-sustrato de la fermentación de los oligosacáridos obtenidos del hidrolizado $100^{\circ} \mathrm{C}-60 \mathrm{~min}$ 53 


\section{ÍNDICE DE FIGURAS}

1. Composición química del material lignocelulósico de distintas partes de la planta de

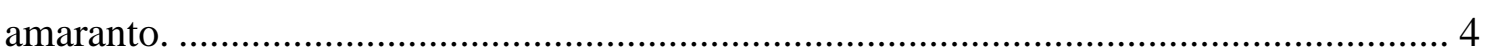

2. Estructura del xilano y los sitios de su ataque por enzimas xilanolíticas.................... 5

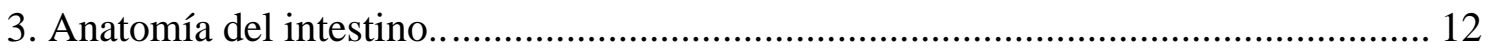

4. Componentes de monosacáridos de oligosacáridos no digeribles ............................. 14

5. Transformación de la glucosa y derivación del ácido pirúvico a principales productos de la respiración y fermentaciones bacterianas. ........................................................ 15

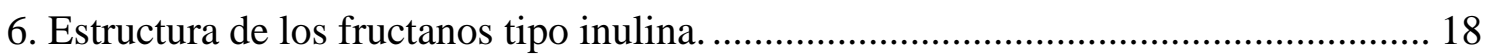

7. Estructura del homogalacturonano. Polímero lineal de uniones $\alpha-(1,4)$ de unidades de ácido galacturónico........................................................ 19

8. Metodología general de trabajo para obtener los hidrolizados y evaluar su actividad

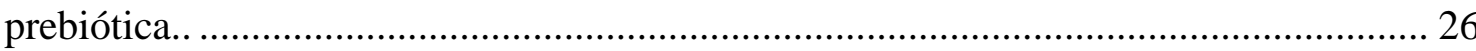

9. Cinética de hidrólisis obtenidas bajo las condiciones de concentración de ácido y tiempo de hidrólisis, analizadas a temperatura constante de $121^{\circ} \mathrm{C}$............................. 34

10. Cinéticas de crecimiento de la fermentación in vitro de los hidrolizados obtenidos a

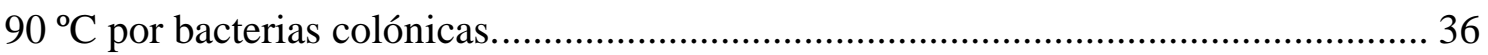

11. Cinéticas de crecimiento de la fermentación in vitro de los hidrolizados obtenidos a $100{ }^{\circ} \mathrm{C}$ por bacterias colónicas

12. Cambio de $\mathrm{pH}$ durante la fermentación in vitro de los hidrolizados obtenidos a $90{ }^{\circ} \mathrm{C}$.

13. Cambio de $\mathrm{pH}$ durante la fermentación in vitro de los hidrolizados obtenidos a $100{ }^{\circ} \mathrm{C}$

14. Ejemplo de ácidos orgánicos responsables del descenso de $\mathrm{pH}$ en el medio de cultivo

15. Concentración de ácidos grasos acético, propiónico y butírico en mmol/L formados durante la fermentación de los hidrolizados obtenidos a $90{ }^{\circ} \mathrm{C}$. 
16. Concentración de ácidos grasos acético, propiónico y butírico en mmol/L formados durante la fermentación de los hidrolizados obtenidos a $100{ }^{\circ} \mathrm{C}$ 46

17. Perfil de elución de los estándares: dextrano y glucosa, y del hidrolizado en Sephadex G-25 50

18. Cinéticas de crecimiento de la fermentación in vitro por bacterias colónicas de los oligosacáridos, del hidrolizado obtenido a $100^{\circ} \mathrm{C}$ por 60 min y de los controles inulina y pectina

19.Cambio de $\mathrm{pH}$ durante la fermentación de los oligosacáridos, del hidrolizado de $100{ }^{\circ} \mathrm{C}-60 \mathrm{~min}$ y de los controles inulina y pectina. 54

20. Concentración de ácidos grasos acético, propiónico y butírico en $\mathrm{mmol} / \mathrm{L}$ formados durante la fermentación de los oligosacáridos obtenidos a partir del hidrolizado $100{ }^{\circ} \mathrm{C}$ $60 \mathrm{~min}$ 55 


\section{GENERALIDADES}

\subsection{Amaranto}

El cultivo de amaranto pertenece a la familia Amaranthaceae y posee características agronómicas y alimentarias muy prometedoras para mejorar la calidad de vida de las zonas áridas y semiáridas, debido a que es una planta muy versátil que se puede utilizar como grano, verdura o forraje; por ejemplo, la semilla o huautli era de consumo habitual por los aztecas, junto con el maíz, el frijol y la calabaza; los mayas la cultivaron en Guatemala y los incas en Sudamérica. La planta tierna que se conoce como huauhquilitl o quintonilli, se empleaba como verdura; en tanto, los tallo y las hojas verdes, ya maduras, se comían cocidas con sal o tequesquite (Arellano y Galicia, 2007; Morales et al., 2009).

Las especies del género Amaranthus L. (Amaranthaceae o Amarantáceas) están ampliamente distribuidas en el mundo, en particular en las regiones tropicales, subtropicales y de clima templado. Esta familia comprende más de 60 géneros y cerca de 800 especies de plantas herbáceas anuales o perenes. Existen tres especies del género Amaranthus que producen grandes inflorescencias repletas de semillas y son A. hypochondriacus, A. cruentus y A. caudatus, que se cultivan en México, Guatemala y Perú, respectivamente (Arellano y Galicia, 2007; Morales et al., 2009).

La planta de amaranto tiene hojas anchas, brillantemente coloreadas con una panícola (panoja) parecida a la del sorgo con una longitud promedio de 50 a $90 \mathrm{~cm}$, que está formada por muchas espigas que contienen numerosas flores pequeñas en las que se encuentran contenidos los granos. Este grano o semilla de amaranto posee características nutricionales muy interesantes; una de las más importantes es su contenido y calidad de proteínas. Cuyo contenido de proteína total de diversas variedades de amaranto va de 13 a $18 \%$ de materia seca, y estas proteínas tienen un balance de aminoácidos muy aceptable ya que poseen concentraciones elevadas de lisina $(0.73-0.84 \%)$, aminoácido esencial que es deficiente en la mayoría de los cereales. También contiene almidón (58 - 66\%), posee de 9 a $16 \%$ de fibra dietética; su contenido de lípidos varía de 3.1 a $11.5 \%$ donde el ácido linoleico es el principal constituyente. Aporta también cantidades nada despreciables de calcio fosforo, potasio, zinc, vitamina E y vitaminas del complejo B. Por otro lado las hojas del amaranto son buenas proveedoras de vitaminas A y $\mathrm{C}$ y se pueden comparar desde el punto de vista 
de su aporte nutricio con las espinacas (Spinacia oleracea). Por estas razones el amaranto puede contribuir de forma importante al incluirlo en la dieta de la población de los países latinoamericanos (Arellano y Galicia, 2007; Morales et al., 2009).

En la república Mexicana la zona de producción y cultivo de amaranto es la central, en la Tabla 1 aparece la producción de cada uno de los estados.

Tabla 1. Principales estados productores de amaranto en el país.

\begin{tabular}{|c|c|c|c|c|c|}
\hline Estado & $\begin{array}{c}\text { Superficie } \\
\text { sembrada } \\
\left(\mathbf{m}^{2}\right)\end{array}$ & $\begin{array}{c}\text { Superficie } \\
\text { cosechada } \\
\left(\mathbf{m}^{2}\right)\end{array}$ & $\begin{array}{c}\text { Producción } \\
(\mathrm{kg})\end{array}$ & $\begin{array}{c}\text { Rendimiento } \\
\left(\mathrm{kg} / \mathrm{m}^{2}\right)\end{array}$ & $\begin{array}{c}\text { Valor } \\
\text { producción } \\
\text { (miles de } \\
\text { pesos) }\end{array}$ \\
\hline $\begin{array}{l}\text { Distrito } \\
\text { Federal }\end{array}$ & $1.37 \times 10^{6}$ & $1.37 \times 10^{6}$ & $1.76 \times 10^{5}$ & 0.129 & $3,942.5$ \\
\hline $\begin{array}{l}\text { Estado de } \\
\text { México }\end{array}$ & $2.12 \times 10^{6}$ & $2.12 \times 10^{6}$ & $3.72 \times 10^{5}$ & 0.175 & $3,335.1$ \\
\hline Morelos & $2.08 \times 10^{6}$ & $2.08 \times 10^{6}$ & $2.84 \times 10^{5}$ & 0.136 & $4,279.4$ \\
\hline Puebla & $2.265 \times 10^{7}$ & $2.118 \times 10^{7}$ & $2.493 \times 10^{6}$ & 0.118 & $8,920.4$ \\
\hline Querétaro & $5 \times 10^{4}$ & $5 \times 10^{4}$ & $4 \times 10^{3}$ & 0.080 & 59.1 \\
\hline Tlaxcala & $5.21 \times 10^{6}$ & $1.84 \times 10^{6}$ & $2.76 \times 10^{5}$ & 0.15 & $1,220.0$ \\
\hline
\end{tabular}

Fuente: Anuario Estadístico de Producción Agrícola 2011. SAGARPA

La producción nacional en base seca del grano de amaranto oscila entre 0.11 a 0.17 $\mathrm{kg} / \mathrm{m}^{2}$, y la de otros constituyentes de la planta como es la hoja, de 0.38 a $0.41 \mathrm{~kg} / \mathrm{m}^{2}$, generando con ello una gran cantidad de biomasa (hasta $0.9 \mathrm{~kg} / \mathrm{m}^{2}$ base seca), lo que representa cantidades considerables de residuos agrícolas conocidos como "rastrojos" y son cerca de $5 \times 10^{8} \mathrm{~kg}$. Desafortunadamente el rastrojo de amaranto está siendo subutilizados en nuestro país, pues sus usos están limitados a abono vegetal, alimentación animal y/o a ser quemado a cielo abierto, uso que genera serios problemas de contaminación ambiental. 


\subsection{Material lignocelulósico del rastrojo de amaranto}

Debido a su naturaleza los residuos agrícolas como el rastrojo de amaranto, son una fuente importante de material lignocelulósico, compuesto por lignina, celulosa y hemicelulosa.

La celulosa es el principal componente estructural en plantas, químicamente es un homopolisacárido lineal de unidades de D-glucopiranosas, unidos por enlaces glucosídicos $\beta(1,4)$, donde se forman uniones de hidrógeno entre sus cadenas. Estas uniones dan una estructura estable de microfibrillas cristalinas y también le proporcionan fuerza mecánica, resistencia a la degradación biológica, baja solubilidad en agua y resistencia a la hidrólisis ácida (García, 2002). Sin embargo, puede ser hidrolizada a residuos de D-glucosa por la acción de ácidos como el sulfúrico y el clorhídrico a una temperatura mayor a $125^{\circ} \mathrm{C}$; o por métodos enzimáticos empleando celulasas extracelulares que sintetizan ciertos microrganismos (Badui, 2006).

La lignina no es un hidrato de carbono, sino una cadena de compuestos fenólicos como la vainillina, el aldehído siríngico y los alcoholes coniferílico, sinapílico y cumarílico (Badui, 2006). Físicamente es una sustancia leñosa que proporciona a las plantas estructura y soporte, encontrándose presente en cantidades variables (García, 2002).

Las hemicelulosas crean la matriz en la cual se enredan las fibras de celulosa, son un complejo heteropolimero que incluye además de xilano (homopolimero de xilosa), xiloglucano (heteropolímero de D-xilosa y D-glucosa), glucomanano (D-glucosa y D-manosa), galactoglucomanano (D-galactosa, D-glucosa y D-manosa) y arabinogalactano (D-galactosa y D-arabinosa) (Collins et al., 2005). El xilano es el principal carbohidrato encontrado en la fracción hemicelulósica de los tejidos vegetales y constituye la tercera parte de todo el carbón orgánico renovable sobre la tierra (PazLago y Hernández, 2000).

La composición química del material lignocelulósico del amaranto determinada por Arce (2011), aplicando metodologías TAPPI (Technical Association of the Pulp and Paper Industry) mostró los componentes y cantidades que se presentan en la Figura 1, de donde se puede observar que la celulosa en general es el componente que se encuentra en mayor cantidad a excepción de la hoja que reportó un mayor contenido de extraíbles como compuestos lipofílicos (ácidos grasos, glicéridos, ceras, terpenos) y 
fenólicos. Respecto al contenido de hemicelulosa este es mayor en el tallo y es de $26 \mathrm{~g}$ de materia seca. De acuerdo con lo anterior esta parte de la planta representa una fuente considerable de xilano que puede ser digerido química o enzimáticamente a unidades de más pequeñas para ser evaluado como fuente de carbono y energía en procesos de fermentación.

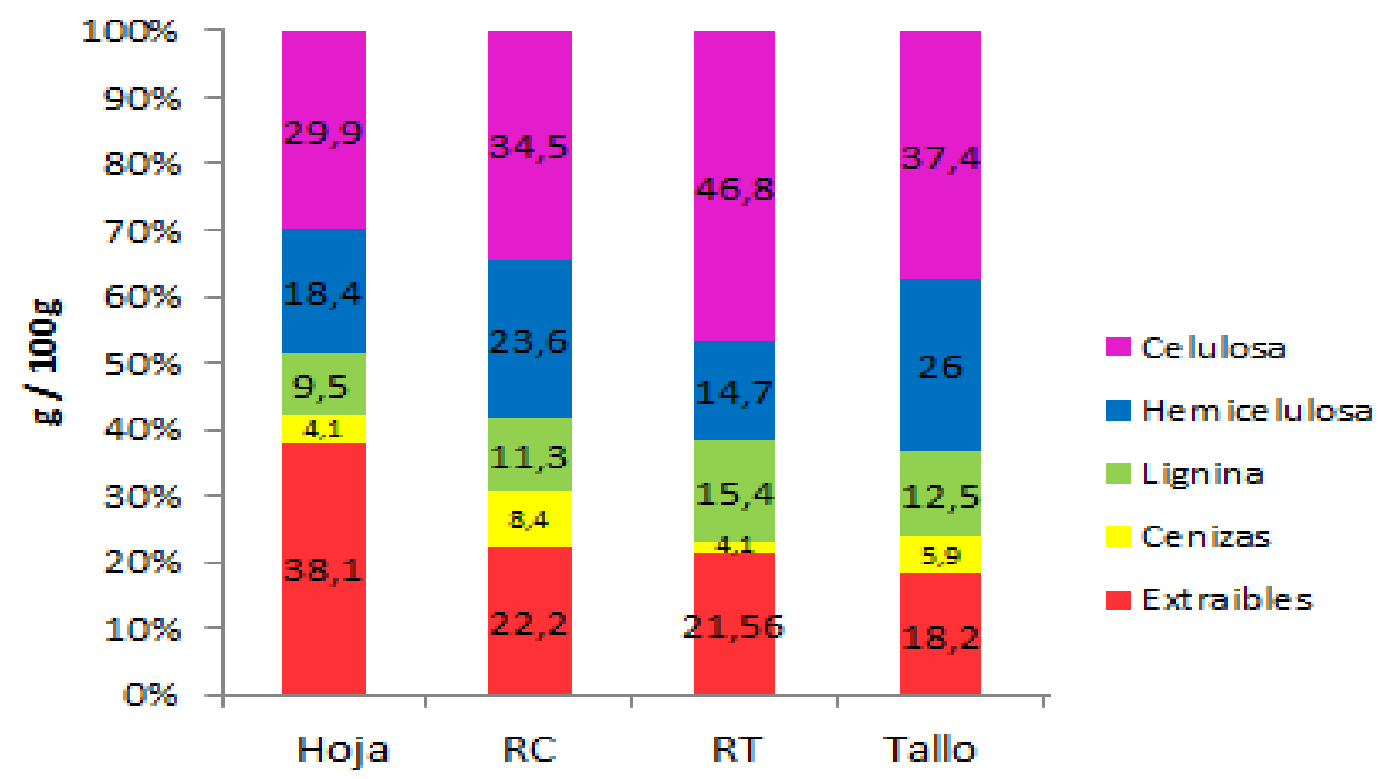

Figura 1. Composición química del material lignocelulósico de distintas partes de la planta de amaranto. RC: rastrojo compuesto (tallo, hoja, inflorescencia y grano). RT: rastrojo T (tallo, hoja e inflorescencia). Fuente: Arce, 2011.

La complejidad de la estructura del xilano varía de acuerdo con las especies vegetales. El xilano existe como $O$-acetil-4- $O$-metilglucuronoxilano en maderas duras y como arabino-4- $O$-metilglucuronoxilano en maderas suaves, mientras que el xilano en hierbas y plantas anuales son típicamente arabinoxilanos. Debido a esta heterogeneidad y complejidad, la hidrólisis completa del xilano requiere de una larga variedad de enzimas que actúan cooperativamente (Figura 2). En este sentido, las: endo 1,4- $\beta$-D-xilanasas (EC.3.2.1.8) aleatoriamente rompe la cadena principal de xilano, $\beta$-D-xilosidasa (EC.3.2.1.37) que corta monómeros de xilosa del extremo no reductor de xilooligosacáridos y xilobiosa, mientras que la eliminación de los grupos laterales se cataliza por $\alpha$-L-arabinofuranosidasa (EC.3.2.1.55), $\alpha$-D-glucoronidasa (EC.3.2.1.139), acetilxilanoesterasas (EC.3.1.1.72), ácido ferúlicoesterasas (EC.3.1.1.73) y ácido pcumáricoesterasas (EC 3.1.1.-) (Collins et al., 2005). 


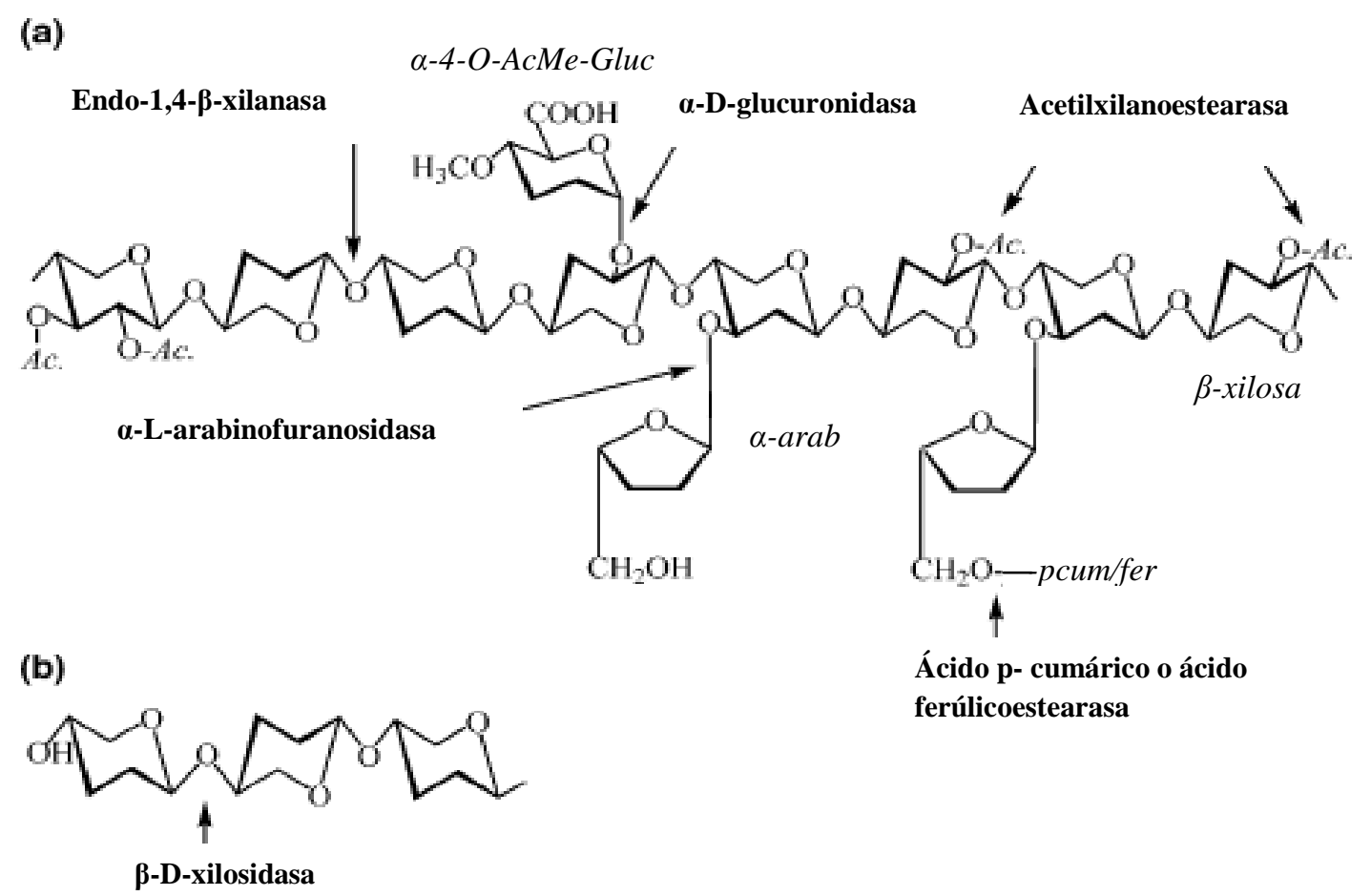

Figura 2. (a) Estructura del xilano y los sitios de su ataque por enzimas xilanolíticas. El esqueleto base del substrato está formado de uniones $\beta-1,4$ de residuos de xilosa. Ac., grupo acetilo; $\alpha$-arab., $\alpha$-arabinofuranosidasa; $\alpha-4-O-A c M e-G l u c .$, a-4-O-ácido metilglucurónico; pcum., ácido p-cumárico; fer., ácido ferúlico.

(b) Hidrólisis de xilooligosacáridos por xilosidasa. Fuente: Collins et al., 2005.

Se conoce que el complejo enzimático xilanolítico es producido por hongos, actinomicetos y bacteria, siendo los más importantes Aspergillus, Trichoderma, Streptomyces, Phanerochaete, Ruminococcus, Fibrobacterias, Clostridia y Bacillus. Los nichos ecológicos de estos microorganismos son diversos, los hongos incluyen entornos en donde los que materiales vegetales se acumulan y deterioran, y las bacterias el rumen de los rumiantes (Collins et al., 2005). 


\subsection{Hidrólisis ácida}

La hidrólisis química de materiales lignocelulósicos ha sido intensamente investigada y desarrollada en el siglo XX y llevada a escala comercial desde 1909 en EUA y otros países de Europa y Asia, para fermentar la glucosa y obtener etanol, empleando madera como sustrato. La factibilidad económica de estos procedimientos depende principalmente de bajos costos en la materia prima, en energía, operación y bajos costos de inversión (Aguilar y Canizales, 2004).

La hidrólisis química puede ser ácida o básica, en el presente trabajo se empleó la ácida. La hidrólisis ácida está en función de la concentración de ácido, temperatura y tiempo de reacción (Aguilar y Canizales, 2004). Ácidos diluidos pueden ser utilizados como catalizadores de una hidrólisis limitada llamada prehidrólisis, esta consiste en la hidrólisis de la fracción hemicelulósica, las fracciones remanentes celulosa y lignina permanecen casi intactas. Los ácidos sulfúrico $\left(\mathrm{H}_{2} \mathrm{SO}_{4}\right)$, clorhídrico $(\mathrm{HCl})$, fluorhídrico (HF) o acético $\left(\mathrm{CH}_{3} \mathrm{COOH}\right)$ son los comúnmente empleados como catalizadores. Estos ácidos antes mencionados proporcionan protones que rompen las uniones éter heterocíclicas entre los monómeros de azúcares de las cadenas poliméricas formadas por las hemicelulosas y la celulosa. La ruptura de estas uniones proporciona distintos componentes, principalmente azúcares como xilosa, glucosa y arabinosa. Otros componentes relacionados son oligomeros, furfural y ácido acético. Una hidrólisis cuantitativa de hemicelulosas puede ser desarrollada casi sin el daño a la celulosa porque las uniones en hemicelulosas son menos fuertes (Aguilar et al., 2002).

Por mencionar un ejemplo, los ácidos $\mathrm{H}_{2} \mathrm{SO}_{4}$ y $\mathrm{HCl}$ son utilizados en concentraciones entre $2-5 \%$ a temperaturas alrededor de $160^{\circ} \mathrm{C}$ y presiones de 10 atmosferas. En estos procesos la concentración de ácido y temperatura son cruciales en la formación de compuestos tóxicos. Temperaturas moderadas $\left(<160^{\circ} \mathrm{C}\right)$ son adecuadas para la hidrólisis de hemicelulosas, promoviendo la descomposición de pequeños azúcares. Por otro lado temperaturas superiores a $160^{\circ} \mathrm{C}$ favorecen la hidrólisis de celulosa, generando alta cantidad de productos de descomposición de azúcares y lignina. Otro factor importante en los procesos de hidrólisis es el tiempo de reacción. Si el tiempo de reacción en tan largo como $1 \mathrm{~h}$, las concentraciones de xilosa disminuyen debido a su degradación. A altas temperaturas y presiones, la glucosa y la xilosa pueden ser degradados a furfural e hidroximetilfurfural (HMF), respectivamente, y cuando estos últimos son degradados se obtiene ácido fórmico. Junto a estos compuestos otras sustancias son formadas como los 
ácidos siríngico, vainíllico, caproico, caprílico, pelargonico y palmítico, los cuales son tóxicos para los microorganismos durante la fermentación. Una combinación de métodos pueden ser utilizados para reducir la concentración de estos inhibidores como son concentración del hidrolizado por evaporación con vacío, para reducir los contenidos de compuestos volátiles como ácido acético, furfural y ácido vainíllico, sin embargo con este método también se incrementa la concentración de compuestos tóxicos no-volátiles. Para eliminar estos últimos se puede utilizar carbón activado, tierra de diatomeas, resinas de intercambio iónico o el ajustar el pH con una combinación de bases y ácidos, por ejemplo el ajuste del $\mathrm{pH}$ de hidrolizados de bagazo de caña primero a pH 9 con $\mathrm{NaOH}$ o $\mathrm{Ca}(\mathrm{OH})_{2}$ y después a 6.5 con $\mathrm{H}_{2} \mathrm{SO}_{4}$ se remueven compuestos fenólicos y se reduce la concentración de furfural e HMF (Mussatto y Roberto, 2004).

De acuerdo con los anterior, las reacciones de hidrólisis de polímeros de azúcares en medios ácidos son muy complejas, ya que estas reacciones no son específicas, pues una variedad de procesos toma lugar simultáneamente a la hidrólisis del xilano, incluyendo remoción de extraíbles, solubilización de lignina, neutralización de cenizas y reacciones que involucran proteínas (Vegas et al., 2004).

A partir de la ruptura del xilano contenido en materiales lignocelulósicos, se obtiene xilooligomeros o xilosa con aplicaciones en alimentos, farmacia o medicina. Como ingredientes alimenticios, la xilosa puede ser bioconvertida a xilitol, un polialcohol con importantes aplicaciones como edulcorante, y los xilooligosacáridos (XOS) tienen acciones prebióticas, ya que favorecen el crecimiento de bifidobacterias, suprimiendo el crecimiento de Clostridium, y causando un efecto bacteriostático contra Vibrio anguilarum (Vegas et al., 2004). 


\subsection{Fibra dietética}

El interés por la fibra en nutrición humana aparece con fuerza a partir de los trabajos de Burkitt (1974) que se interesaron por la relación entre el consumo inadecuado de fibra y el aumento de enfermedades degenerativas en las sociedades desarrolladas. Actualmente y después de treinta años de investigación, la fibra dietética forma parte de los que se considera una dieta saludable (Escudero y González, 2006).

A medida que aumentan los conocimientos sobre la fibra tanto a nivel estructural como en sus efectos fisiológicos la American Association of Cereal Chemist en 2001 definió a la fibra dietética como la parte comestible de las plantas o hidratos de carbono análogos, que son resistentes a la digestión y absorción en el intestino delgado humano, con fermentación completa o parcial en el intestino grueso (Escudero y González, 2006).

La fibra dietética puede ser clasificada dependiendo de su reacción con el agua en dos tipos: fibra soluble e insoluble. La fibra soluble es la fracción de la fibra dietética total que se caracteriza por formar una dispersión y/o geles viscosos cuando se combina con agua en el tracto intestinal, incluye gomas, mucílagos, pectinas, ciertas hemicelulosas y celulosa modificada. Cierto tipo de fibra soluble tienen actividad prebiótica, por lo tanto es sustrato para las bacterias colónicas benéficas y los productos de su metabolismo dan lugar a los efectos fisiológicos como son disminución de glucosa y colesterol en sangre y estimulación de apoptosis (Gibson y Robenfroid, 2008). La fibra insoluble es la forma más común de la fibra; aproximadamente el $75 \%$ de la fibra dietética es de este tipo. No se disuelve en agua y sus componentes principales son celulosa, hemicelulosa y lignina. $\mathrm{Su}$ acción principal en el organismo es el aumento de la masa fecal y la disminución del tiempo de tránsito intestinal (García, 2002). Esta situación provoca que se incremente la viscosidad, se reduzca el tiempo de residencia de los constituyentes del alimento en el intestino y que sólo las moléculas fácilmente absorbibles atraviesen la pared intestinal, también aceleran la secreción de ácidos biliares y de colesterol; éste se une a la fibra y como tal es eliminado en las heces, reduciendo la posibilidad de su reabsorción (Badui, 2006).

Los alimentos que contienen fibra dietética son las frutas, verduras, semillas no refinadas de los cereales, leguminosas y oleaginosas, específicamente en la tabla 2, se muestran distintas fuentes alimenticias (García, 2002); hoy en día se agrega fibra dietética como aditivo a alimentos procesados (Badui, 2006). 
Tabla 2. Algunas fuentes de fibra dietética.

\begin{tabular}{|c|c|c|c|c|}
\hline \multicolumn{3}{|c|}{ FIBRA INSOLUBLE } & \multicolumn{2}{|c|}{ FIBRA SOLUBLE } \\
\hline CELULOSA & HEMICELULOSA & LIGNINA & GOMAS & PECTINAS \\
\hline $\begin{array}{c}\text { Harina entera de } \\
\text { trigo }\end{array}$ & Salvado & $\begin{array}{c}\text { Cereales para } \\
\text { desayuno }\end{array}$ & Avena & Calabaza \\
\hline Salvado de trigo & Cereales & Salvado & Frijol & Manzana \\
\hline Col & Granos enteros & Verduras & & $\begin{array}{l}\text { Frutas } \\
\text { cítricas }\end{array}$ \\
\hline Chícharos & Col & Fresas & & Coliflor \\
\hline Frijol verde & Mostaza & Berenjena & & Frijol verde \\
\hline Habas & Remolacha & Peras & & Col \\
\hline Brócoli & Frijol verde & & & Zanahorias \\
\hline Manzanas & & & & Fresas \\
\hline Zanahorias & & & & Papas \\
\hline
\end{tabular}

Fuente: García, 2002

El rastrojo de amaranto es fuente de fibra dietética, estudios realizados por Arce (2011), mostraron que la hoja y el tallo contienen un 97 y $99 \%$ de fibra insoluble. Debido a ello es necesario realizar la hidrólisis de esta fibra para solubilizarla y obtener un prebiótico que permita favorecer el crecimiento de bacterias colónicas benéficas. 


\subsection{Probióticos}

El concepto de probiótico fue definido originalmente en 1965, sin embargo discusiones recientes coinciden en que los probióticos son organismos vivos que cuando son ingeridos en las cantidades adecuadas confieren beneficios a la salud del huésped (Gibson y Robenfroid, 2008). Los más conocidos son las bifidobacterias que son bacilos pleomorfícos anaerobios que predominan en el colon de bebes en lactancia y representan hasta el $95 \%$ de todas las bacterias cultivables; y las bacterias ácido lácticas que son un amplio grupo de microrganismos gram-positivos, no formadores de esporas, catalasa negativos, desprovistos de citocromos y estrictamente fermentativos con ácido láctico como producto final predominante. Las bacterias ácido lácticas están asociadas a diversos hábitats, sobre todo aquellos ricos en nutrientes como los alimentos (leche, carne y bebidas) y materiales vegetales, los cuales son capaces de fermentar o descomponer. Algunas cepas de bacterias lácticas habitan la cavidad oral, el tracto intestinal y la vagina, y pueden influir benéficamente en dichos ecosistemas humanos (Holzapfel y Schillinger, 2002).

Un probiótico es capaz de resistir la acidez del estómago y sustancias características del tracto gastrointestinal como sales biliares para poder llegar a su sitio de acción donde se une a las células epiteliales y al moco gastrointestinal (Barrio, 2006). Su implantación en la microflora causa modificaciones selectivas en su composición, ya que se presentan competencias por nichos ecológicos y nutrimentos, provocando distintos efectos en las funciones del intestino del hospedero. El probiótico pasa a ser un miembro más de la microflora, crea y establece interacciones en ella, con sus distintos filos/grupos/especies de células procariotas así como con las células eucariotas de la pared colónica (incluyendo el epitelio y el tejido linfático asociado al intestino). Finalmente y como consecuencia de estas nuevas interacciones celulares probiotico-procariotico y probiotico-eucariotico, se crean modulaciones nuevas y otras se hacen más fuertes, de las funciones colónicas, traduciéndose en una mejor salud y bienestar y/o reducción del riesgo de enfermedades (Gibson y Robenfroid, 2008).

Algunos efectos sobre los beneficios a la salud son alivio de intolerancia a la lactosa, reducción de alergias alimentarias y padecimiento atópicos, alteración de poblaciones y/o actividades de la microbiota oral, prevención de cáncer, estimulación del sistema inmune, disminución del colesterol en sangre, reducción de padecimientos de intestino 
inflamado (padecimiento de Crohn), reducción de diarrea, resistencia a la adherencia y colonización por bacterias patógenas (Swennen et al., 2006).

Las cepas probióticas se han encontrado tradicionalmente en alimentos fermentados como yogurt, carne y vegetales fermentados, sin embargo en la actualidad también los podemos encontrar en preparaciones farmacéuticas (Gibson y Robenfroid, 2008). Las preparaciones probióticas comerciales generalmente son mezclas de lactobacilos y bifidobacterias, aunque también se utilizan algunas levaduras tales como Sacharomyces (Tabla 3).

Tabla 3. Especies microbianas cuyas cepas tienen aplicación como probióticos.

\begin{tabular}{cccc}
\hline ESPECIES DE & ESPECIES DE & OTRAS & \\
LACTOBACILLUS & BIFIDOBACTERIUM & $\begin{array}{c}\text { BACTERIAS } \\
\text { LÁCTICAS }\end{array}$ & NO LÁCTICAS \\
\hline L. rhamnosus & B. longum & $\begin{array}{c}\text { Streptococcus } \\
\text { thermophilus }\end{array}$ & Bacillus cereus \\
L. acidophilus & B. breve & Lactococcus & Saccharomyces \\
cremoris & cerevisiae \\
L. bulgaricus & B. infantis & Lactococcus lactis & Saccharomyces \\
L. gasseri & B. bifidum & & boulardii
\end{tabular}

$\begin{array}{ll}\text { L. amylovorus } \quad \text { B. animales } & \end{array}$

L. crispatus B. lactis

L. johnsonii

L. paracasei

L. plantarum

L.reuteri

Fuente: Macfarlane y Cummings, 1999; Holzapfel y Schillinger, 2002.

Para asegurar que los probióticos proporcionen los beneficios esperados al consumidor, el producto debe tener más de un millón de células viables por mL (Lourens-Hatting y Viljoen, 2001). 


\subsubsection{Metabolismo en el colón}

Dentro de nuestro organismo existen cerca de un trillón de microorganismos que conforman la microbiota intestinal (Figura 3) y que en términos generales influyen directamente sobre el estado de salud del hospedero. Una de las funciones de la microbiota es la de fermentar componentes no digeribles de la dieta como oligosacáridos no digeribles (OND) y mucus endógeno producido por el epitelio intestinal, este es un ejemplo de la relación simbiótica que muestra beneficios a la salud del hospedero a partir de la acción de un amplio conjunto de enzimas microbianas (Gibson y Robenfroid, 2008).

\section{Intestino delgado}

No. Bacterias: $10^{4}-10^{6} / \mathrm{ml}$ Ej. Lactobacillus, cocos gram -positivos.

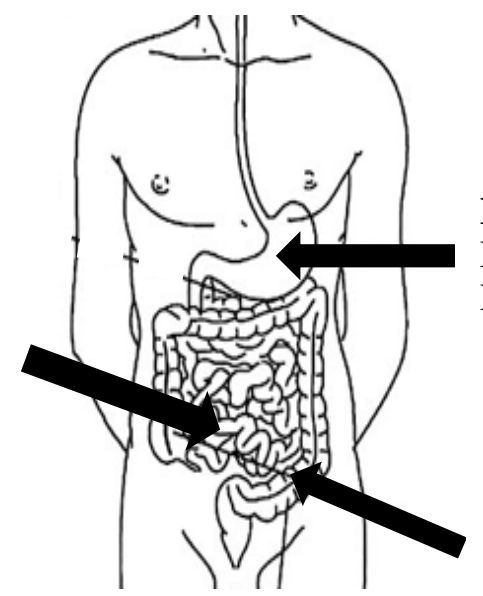

Estómago

No. Bacterias: $10^{3} / \mathrm{ml}$ Ej. Helicobacter pylori

\section{Colón}

No. Bacterias: $10^{12} / \mathrm{g}$

Ej. Bacteroides, bifidobacteria, clostridia, Peptostreptococcus, fusobacteria, Lactobacillus, enterobacteria, Enterococcus, eubacteria, etc.

Figura 3. Anatomía del intestino. Diferentes regiones del intestino son colonizados por diferentes tipos de comunidades microbianas, tanto en términos de diversidad de especies y números reales. El intestino grueso distal es la zona más alta de colonización con más de 500 especies diferentes y hasta 100 mil millones de microorganismos por gramo. Las condiciones del estómago reducen la carga microbiana a menos de $10^{3}$ UFC (por gramo) llega a $10^{4}-10^{7}$ en el intestino delgado y $10^{10}-10^{12}$ por gramo en el colon. Fuente: Gibson y Robenfroid, 2008.

La indigestibilidad de los OND resulta de la configuración de las uniones glicosídicas entre las unidades monoméricas de azúcares o la selectividad del sustrato de enzimas digestivas gastrointestinales. La mayoría de los OND tienen una configuración $\beta$ y no pueden ser degradados por enzimas digestivas gastrointestinales, las cuales son específicas a uniones $\alpha$-glicosídicas. Sin embargo hay OND con configuración $\alpha$ y los cuales en principio pueden ser degradados por enzimas $\alpha$-glucolíticas. Además la enzima $\beta$-galactosidasa, localizada en el borde la membrana del intestino delgado tiene 
el potencial de degradar $\beta$-galactooligosacáridos. Sin embargo la degradación de OND con uniones $\alpha$-glicosidicas o $\beta$-galactooligosacáridos por las enzimas digestivas gastrointestinales antes mencionadas es bajo porque las enzimas usualmente tienen únicamente actividades débiles y/o muestran selectividades a otros sustratos (Swennen et al., 2006).

Los OND que son solubles en agua es muy probable que sean fermentados en el colón. $\mathrm{Su}$ utilización es mediada por enzimas hidrolíticas de bacterias del colón. Muchas especies producen una amplia variedad de enzimas glicolíticas que hidrolizan diferentes OND que se muestran en la Tabla 4. Sin embargo su fermentación está fuertemente influenciada en general por la estructura química de los OND, la identidad de sus unidades de azúcares monoméricas (Figura 4), su grado de polimerización (GP), el tipo de enlace entre las unidades, la complejidad de la molécula (lineal o ramificada) y su posible unión a moléculas que no son hidratos de carbono (Swennen et al., 2006).

Tabla 4. Enzimas glicolíticas de bacterias del colón.

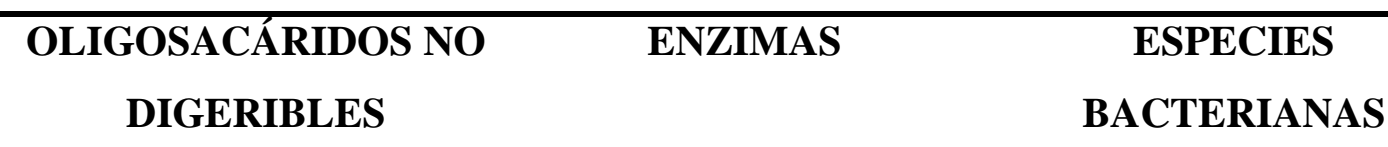

\begin{tabular}{ccc}
\hline$\beta$-Glucooligosacáridos & $\beta$-Glucosidasa & Bifidobacteria, Bacteroides \\
$\alpha$-Glucooligosacáridos & $\alpha$-Glucosidasa & Bifidobacteria, Bacteroides \\
Fructooligosacáridos & $\beta$-Fructofuranosidasa/ & Bifidobacteria, Lactobacillus, \\
& fructanasa & Clostridia, Bacteroides. \\
$\beta$-Galactooligosacáridos & $\beta$-Galactosidasa & Bifidobacteria \\
$\alpha$-Galactooligosacáridos & $\alpha$-Galactosidasa & Bifidobacteria, Lactobacillus, \\
& & Bacteroides. \\
\hline
\end{tabular}

Fuente: Swennen et al., 2006

La acción de estas enzimas específicas genera monosacáridos, y su transporte (por ejemplo glucosa) hacia el interior de la célula es mediado vía el sistema fosfoenolpiruvato:fosfotransferasa (PEP:PTS) una vez dentro de la célula inicia su degradación con una fosforilación que activa a la molécula para reacciones posteriores (Raccach, 2004).

D-glucosa + ATP $\stackrel{\text { hexoquinasa }}{\longrightarrow}$ glucosa-6P + ADP 
Este producto fosforilado continúa su transformación a través de diversas vías catabólicas, mediante las cuales los microorganismos obtienen su energía. La entrada de las pentosas en las vías catabólicas de los hidratos de carbono, se realiza por medio de reacciones parecidas. La D-ribosa es utilizada por algunos microorganismos después de su conversión a ribosa-5P. Por su parte, la xilosa antes de ser fosforilada puede ser convertida en xilulosa. En la Figura 5 se muestra de manera muy general, la degradación de una hexosa, de glucosa a piruvato y la oxidación de éste por vía respiratoria y fermentativa. En este esquema, se observa que el piruvato ocupa una posición crucial, por una parte, se tiene que la glucólisis y formación de piruvato se pueden efectuar a través de cuatro vías metabólicas diferentes; por otra, que de esta encrucijada irradian vías terminales distintas que conducen a productos diversos, lo que depende del tipo de microorganismo y de los aceptores finales de electrones presentes en el medio (Ramírez-Gama et al. 2011).

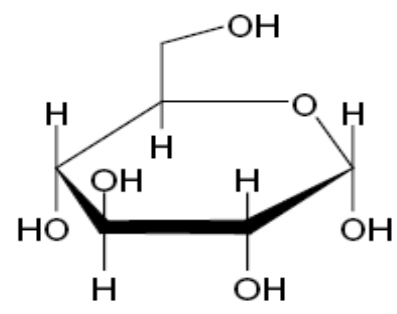

GLUCOSA

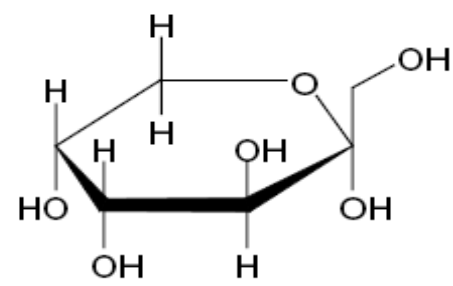

FRUCTOSA

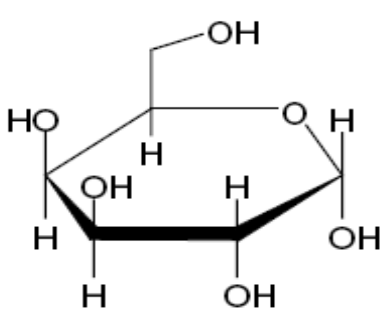

GALACTOSA

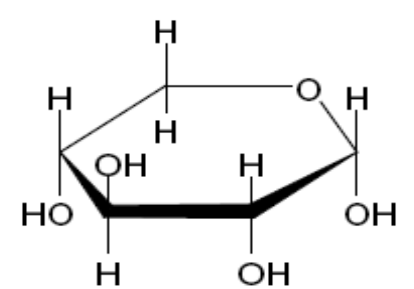

XILOSA

Figura 4. Componentes monosacáridos de oligosacáridos no digeribles.

La mayor fuente de energía de la fermentación colónica se obtiene a partir de hidratos de carbono, la actividad fermentativa difiere de acuerdo al área del intestino, siendo el ciego y el colon más activos metabólicamente, debido a que en estas áreas se presenta un rápido crecimiento bacteriano, un bajo $\mathrm{pH}$ (5-6) y alta generación de ácidos grasos de cadena corta (AGCC) (Gibson y Robenfroid, 2008).

La producción de ácido láctico influye sobre el medio de crecimiento al disminuir el pH con un rápido consumo de fuente de carbono lo que da como resultado un medio de difícil propagación para microorganismos indeseables inhibiendo su crecimiento 
(Marklinder y Löner, 1992). Los principales AGCC generados por la fermentación de hidratos de carbono son acetato, propionato y butirato en un rango del 83-95\% del total de éstos (Nordgaard y Mortensen, 1995) el incremento en la concentración de estos compuestos a nivel colon por la fermentación de hidratos de carbono (simples o compuestos) por parte de la microflora nativa impacta benéficamente sobre la salud (Tungland y Meyer, 2002).

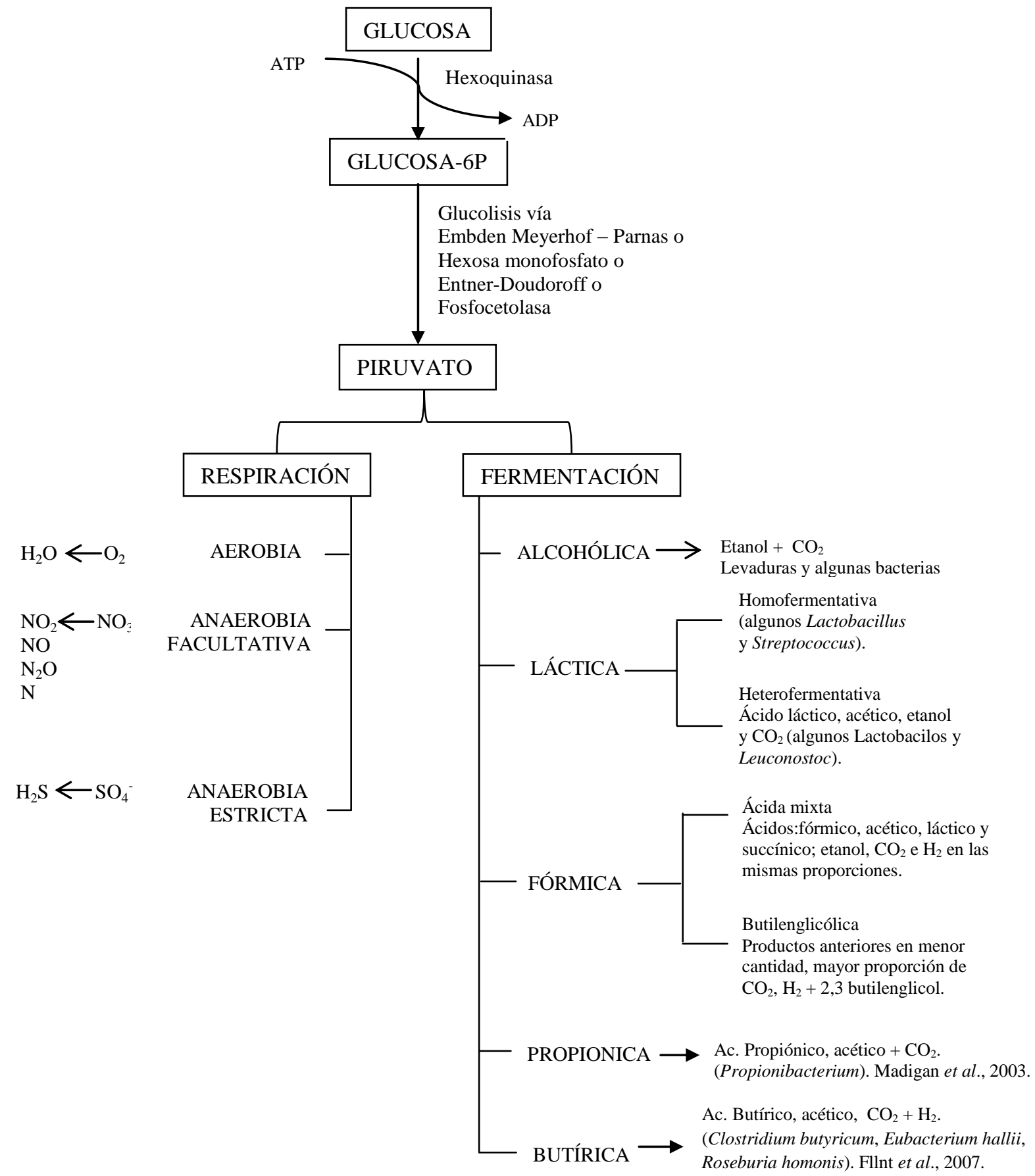

Figura 5. Transformación de la glucosa y derivación del ácido pirúvico a principales productos de la respiración y fermentaciones bacterianas.

Fuente: Ramírez-Gama et al. 2011 
Los ácidos grasos de cadena corta producto del metabolismo de OND se absorben por difusión, o por procesos de intercambio de iones y tienen diferentes funciones in vivo. Los ácidos grasos acético y propiónico se absorben en intestino, pasan a sangre y son distribuidos en diferentes tejidos, el propiónico es metabolizado en el hígado actuando como precursor en la gluconeogénesis y la lipogénesis, mientras que productos del metabolismo del acético son fuente de energía en intestino y en tejidos periféricos como el músculo (Escudero y González, 2006). Por su parte el ácido butírico es fuente de energía para los colonocitos e inhibe la síntesis de DNA, estimula la apoptosis y como tal puede jugar una función en la prevención de cáncer (Gibson y Robenfroid, 2008).

La medida de la fermentación y el perfil de AGCC dependen del sustrato. La velocidad de fermentación de un polisacárido puede ser crítica a su acción en el colon. Una fermentación lenta produce AGCC en el colon distal, y esto puede tener un efecto protector contra carcinogénesis de colon. Por lo tanto, el conocimiento de la medida de la fermentación de la fibra dietética y de los ácidos grasos de cadena corta producidos es de gran importancia. Con el fin de entender la acción de la fibra en el colon, es necesario saber acerca de su poder de fermentación y sobre el estado de la fibra después de la degradación bacteriana. Monitorear la fermentación en el intestino humano es muy difícil. La digestibilidad de la fibra dietética puede medirse a partir de las heces, pero los AGCC se absorbe fácilmente en el colon, y la cantidad encontrada en las heces no describe la situación real. En un estudio in vitro la degradación de los polisacáridos y la producción AGCC y gases se pueden monitorear como una función del tiempo (Karppinen et al., 2000).

Dentro de los componentes no digeribles de la dieta se encuentra la fibra dietética. La fermentabilidad de la fibra dietética de alimentos de origen vegetal puede diferir de las fibras aisladas. Se considera que la fibra dietética soluble, tales como $\beta$-glucanos y arabinoxilanos solubles, son fácilmente fermentada por los microorganismos del colon, mientras que la fibra dietética insoluble es sólo degrada en una pequeña cantidad, lo que resulta en un aumento en el volumen de las heces. La microbiota del colon y/o su actividad se pueden alterar dependiendo de la naturaleza del sustrato que pasa a través del mismo. En adición a la fibra, almidón resistente, oligosacáridos, alcoholes de azúcar y algunas proteínas no digeribles también son sustratos fermentables para la microflora del colon (Karppinen et al, 2000). 


\subsection{Prebióticos}

La mayoría de los oligosacáridos no digeribles contienen entre 3 y 10 monosacáridos, aunque el GP puede ser superior a 60 para algunos OND como la inulina de achicoria. Los oligosacáridos no digeribles comerciales son en general mezclas de oligosacáridos con grados de polimerización variable (Swennen et al., 2006).

La capacidad que tienen los componentes no digeribles de los alimentos para estimular selectivamente el crecimiento y/o actividad de una o varias bacterias del colon que confieren beneficios a la salud, corresponde a la actividad prebiótica. Esto implica que los prebióticos resisten la hidrólisis por enzimas digestivas y/o no se absorben en la parte superior del tracto gastrointestinal (Swennen et al, 2006). Estos compuestos los podemos encontrar adicionados a alimentos procesados como yogurt, cereales, pan, galletas, postres de leche y helados (Gibson y Robenfroid, 2008).

Una clasificación de los prebióticos puede ser de acuerdo a su fuente de obtención (Tabla 5). Los sintéticos son obtenidos a partir de la degradación enzimática de polisacáridos como xilanos, inulina y almidones, así como por la síntesis enzimática a partir de azúcares simples como lactosa y sacarosa mediante el uso de enzimas glicosiltransferasas y glicosidasas (Brito, 2009).

Tabla 5. Clasificación de los compuestos prebióticos con base a su origen.

NATURALES SINTÉTICOS

\begin{tabular}{cc}
\hline Fructooligosacáridos & Lactulosa \\
Galactooligosacáridos & Xilooligosacáridos \\
Oligosacáridos de soya & Lactosacarosa \\
Fibra dietética: & Isomaltooligosacáridos \\
Pectina & Galactooligosacáridos \\
Almidón resistente & \\
$\beta$-glucanos & \\
Arabinoxilanos & \\
\hline
\end{tabular}

Fuente: Mussato y Roberto, 2004; Brito, 2009. 
Los prebióticos naturales se encuentran de forma cotidiana en las partes comestibles y estructurales de plantas y en pequeñas proporciones en leche humana y calostro. Los prebióticos más comunes incluyen oligosacáridos como inulina y su fructooligosacáridos, galactooligosacáridos y lactulosa (Brito, 2009), así como polímeros de hidratos de carbono no digeribles; pectina, hemicelulosa, gomas y almidón resistente que son fermentados parcial o totalmente por la microflora intestinal formando principalmente AGCC, que incluyen el acético, propiónico y butírico (Escudero y González, 2006).

Los prebióticos utilizados como controles en el presente proyecto son la inulina y la pectina, a continuación una descripción de estos compuestos. La inulina es ampliamente utilizada en diferentes alimentos por sus aplicaciones tecnológicas y por sus propiedades prebióticas. Se encuentra naturalmente en muchos alimentos vegetales como cebolla, achicoria de Jerusalem y asparragos. Es un hidrato de carbono formado de unidades de fructosa unidas por enlaces $\beta(2-1)$ con o sin unidades de glucosa terminal (Figura 6). Su grado de polimerización (GP) es variable (Pompei et al., 2008). La inulina en raíz de achicoria y tubérculos como la alcachofa tiene un GP bajo de 10 a 30. El GP más alto de inulina ha sido encontrado en alcachofa globo llegando arriba de 200 residuos de fructosa (Ulloa et al., 2010).

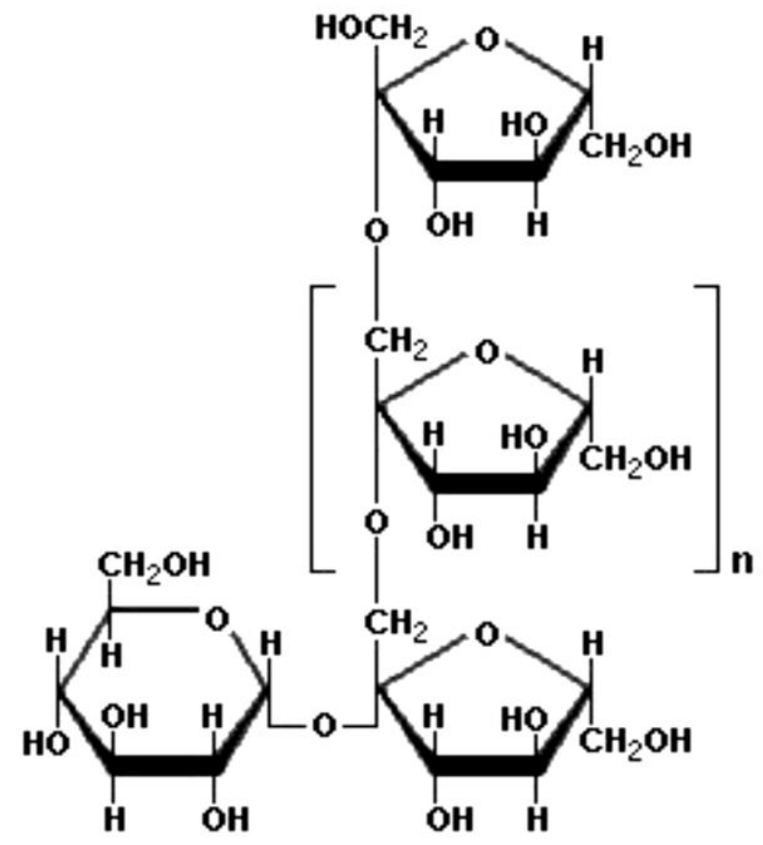

Figura 6. Estructura de los fructanos tipo inulina ( $n=35$ aproximadamente).

Fuente: Ulloa et al., 2010. 
La inulina es fermentada por la microbiota intestinal ya que su adición a la dieta incrementa significativamente el crecimiento de bifidobacterias (Pompei et al., 2008).

Las pectinas son un grupo muy heterogéneo de polímeros respecto a peso molecular (PM) y estructura química. Su componente principal es el ácido $\alpha$-D-1,4-galacturónico (AGal), cuyos grupos carboxilo pueden estar metoxilados en diferentes grados. Las pectinas se componen de regiones suaves y peludas. Las regiones lisas se construyen por cadenas lineales unidas por enlaces $\alpha$-D de unidades 1,4-AGal metoxiladas (Figura 7), mientras que los azúcares neutros se presentan en bajas cantidades o están ausentes. Las regiones peludas consisten en ramnogalacturonano (RMG) I y II. La estructura de RMG I consta de una secuencia alterna de uniones 1,4- $\alpha$-D-AGal y 1,2- $\alpha$-L-ramnosa. Los sitios de ramificación se encuentran en las unidades de ramnosa. Las cadenas laterales que consisten en arabinanos, galactanos o dos diferentes tipos de arabinogalactanos pueden ser unidos en la posición $O-4$. RMG II es un polisacárido complejo con un bajo PM, cuyo esqueleto sólo contiene AGal. Las cadenas laterales constan de ramnosa y algunos azúcares, tales como apiosa, 2-O-metil-xilosa, 2-Ometilfucosa, fucosa 3,4 unida, ácido glucurónico 2- ligado, ácido acérico y otros (Gulfi et al., 2007).

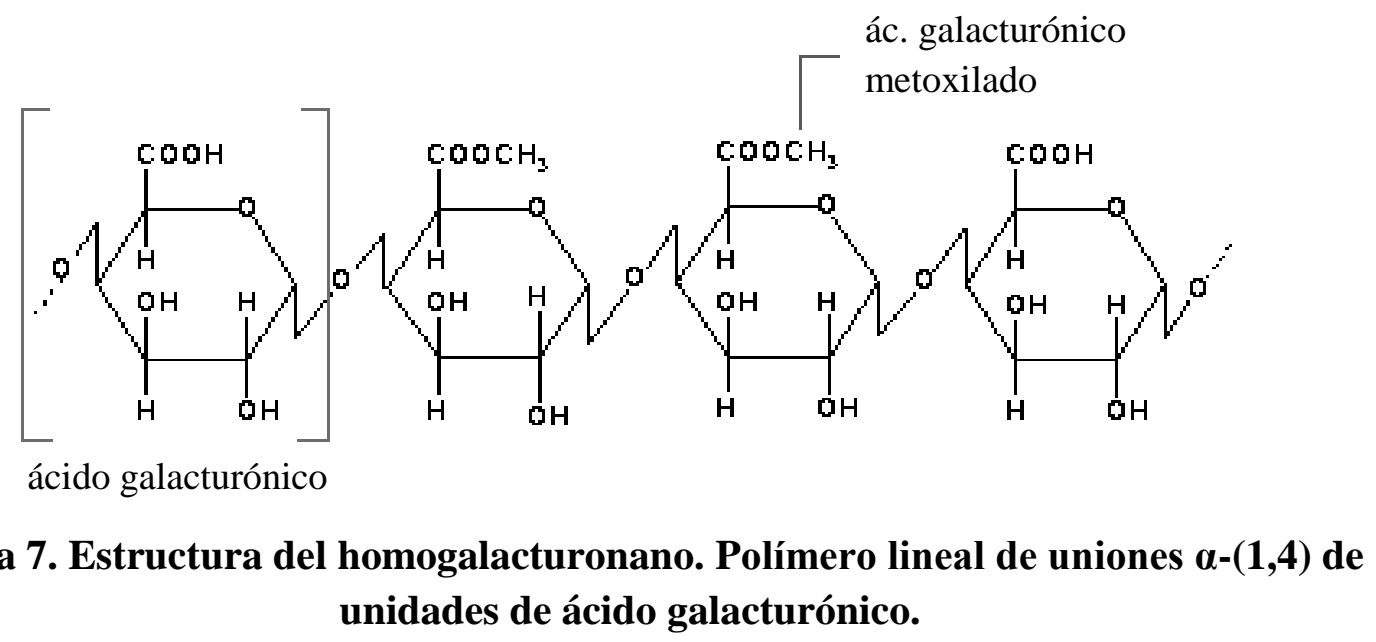

Las pectinas se utilizan en los alimentos como aditivos debido a su capacidad para formar geles a bajas concentraciones, su extracción se lleva a cabo con ácido diluido seguido por la precipitación con un alcohol. Los polisacáridos resultantes son altos en AGal y bajo contenido en azúcares neutros. Por lo tanto, pectinas industriales resultar ser bastante similar en su composición y estructura, independientemente de su 
origen y/o modificación tales como saponificación e hidrólisis parcial (Gulfi et al., 2007). La pectina con un grado de esterificación (GE) de $95 \%$ y fracciones de ácido oligogalacturonico se degradan más lentamente que pectina con GE de $35 \%$. Las pectinas son metabolizadas por muchas especies de la microflora, en las que se incluyen Bacteroides distasonis, Bacteroides ovatus y Bifidobacterium infantis. Del colon humano, enzimas pectinolíticas han sido aislados de Bacteroides sp. y Clostridium butyricum. Las enzimas involucrados en su descomposición son principalmente de tipo endo pectato liasas (EC. 4.2.2.2), y dependiendo del GE de la pectina, se obtienen ácidos oligogalacturónicos de diferentes grados de polimerización, por ejemplo mezclas de di-, tri-y tetra ácido galacturónico (Dongowski y Lorenz, 1998), compuestos que son capaces de promover el crecimiento de bacterias probióticas como bifidobacterias (Olano-Martin et al., 2002).

Como se mencionó anteriormente de la hidrólisis de las hemicelulosas dependiendo de las condiciones en las que se lleva a cabo este proceso se pueden obtener prebióticos como xilooligosacáridos (XOS).

Desde un punto de vista nutricional los XOS usualmente son considerados oligosacáridos no digeribles (OND), los cuales llegando al intestino grueso de manera intacta y ahí pueden ser fermentados por la microbiota colónica a AGCC, lactato, dióxido y carbono e hidrógeno principalmente. Se ha reportado que los XOS tienen un efecto sobre la composición de la microbiota colónica, que resulta en un incremento de bifidobacterias. Estos resultados han sido mostrados por experimentos in vitro como in vivo. Un estudio realizado por Okazaki et al. (1990) para evaluar la fermentación de XOS por microflora intestinal, fue llevada a cabo mediante el apoyo de cinco individuos de prueba sanos, que fueron alimentados con 1-2 g de XOS por día. Se analizaron en las heces el contenido de AGCC y bacterias. Los resultados dieron incrementos de 10-31\% en la proporción de Bifidobacterias respecto del total de la microflora, dicha proporción disminuyó cuando la administración con XOS fue interrumpida, asimismo hubo un incremento significativo en la concentración de ácidos grasos en las heces (Gibson y Robenfroid, 2008).

Los estudios de fermentación de XOS son principalmente desarrollados usando XOS lineales y de bajo peso molecular $(\mathrm{GP}<4)$. Una buena fuente para obtener XOS sustituidos diferentemente son subproductos agroindustriales ricos en xilano, tales como 
maderas duras, mazorca de maíz, salvado de trigo. A través de tratamientos hidrotérmicos el xilano presente en estos productos es (parcialmente) hidrolizado en una variedad de XOS solubles. Las estructuras que se obtienen dependen de las fuentes estructurales del xilano original presente en los subproductos usados (Kabel et al., 2002).

En la definición de fibra dietética están incluidos los OND y corresponden a prebióticos. Hoy en día, más de veinte tipos diferentes de OND están en el mercado mundial, y son extraídos de fuentes naturales, obtenidos por hidrólisis enzimática o por medios químicos. Rafinosa y estaquiosa son comercialmente producidas por extracción directa de suero de leche de soya. Las vías principales para obtener oligosacáridos a partir de polisacáridos son la hidrólisis ácida, degradación termomecánica y oxidativa (Swennen et al., 2006).

Los OND una vez que se producen a través de los métodos antes mencionados, es necesario someter a un refinado adicional. Una serie de técnicas se pueden utilizar para purificarlos como son:

(i) Separación son membranas o soluciones alcohólicas de diferente concentración.

(ii) Extracción con solventes orgánicos.

(iii) Adsorción con silica o arcilla en combinación elución con etanol.

(iv) Evaporación y

(v) Separación cromatográfica de intercambio iónico (Swennen et al., 2006).

Un simbiótico es la combinación de un probiótico exógeno y un prebiótico, el objetivo es que el probiótico pueda proliferar in situ metabolizando el prebiótico, este último puede ser un sustrato específico para el probiótico. Un atributo deseado de un simbiótico es que permita la sobrevivencia del probiótico a través de tracto gastrointestinal (Gibson y Robenfroid, 2008). 


\section{JUSTIFICACIÓN}

En nuestro país los residuos agrícolas y desechos agroindustriales están siendo subutilizados, sin ser la excepción el cultivo de amaranto cada año produce cerca de 50 millones de $\mathrm{kg}$ de rastrojos, que al ser quemados a cielo abierto causan serios problemas de contaminación. Estos materiales pueden ser potencialmente aptos para ser usados como materia prima en la producción de: bioetanol, alimento para animales, biomasa microbiana, etc., ya que son fuente importante de material lignocelulósico, del que se pueden obtener mediante tratamientos químicos, oligosacáridos derivados de la hemicelulosa. Debido a que en la actualidad existen graves problemas de salud en la población mexicana como obesidad, diabetes mellitus, cáncer, hipertensión, hoy en día existe una fuerte tendencia de regresar a consumir lo natural. Considerando lo anterior; se propone solubilizar la fibra dietética del rastrojo de amaranto para obtener una fuente de carbono con actividad prebiótica como los xilooligosacáridos, para favorecer el crecimiento de bacterias colónicas a través de su asimilación, que se reflejara mediante el desarrollo y producción de metabolitos con actividad funcional. 


\section{HIPÓTESIS}

El material lignocelulósico de la planta de amaranto contiene oligosacáridos, los cuales pueden desarrollar actividad prebiótica en condiciones de anaerobiosis, produciendo ácidos grasos de cadena corta por la actividad de las bacterias colónicas; de manera similar a lo que se observa con oligosacáridos presentes en otras plantas como la inulina y la pectina. 


\section{OBJETIVOS}

\subsection{Objetivo general}

Evaluar la actividad prebiótica de hidrolizados del material lignocelulósico de la planta de amaranto (A. hypochondriacus L.)

\subsection{Objetivos particulares}

- Determinar las condiciones de hidrólisis ácida de una muestra de material lignocelulósico de la planta de amaranto que incremente la concentración de oligosacáridos en el hidrolizado.

- Evaluar la actividad prebiótica de los hidrolizados a través de la producción de ácidos grasos de cadena corta producidos en un sistema modelo de fermentación in vitro, que simule las condiciones colónicas. 


\section{MATERIALES Y MÉTODOS}

\subsection{Materiales}

En el presente trabajo se utilizó como muestra del material lignocelulósico harina del tallo de la planta de amaranto, debido a que contiene la mayor cantidad de hemicelulosa. La planta de Amaranthus hypochondriacus L. se recolectó en la zona de Santiago Tulyehualco delegación Xochimilco D.F., en la Ciudad de México. 


\subsection{Metodología general de trabajo}

La metodología que se presenta en la Figura 8 se dividió en; obtención de hidrolizados, evaluación de su actividad prebiótica, separación de oligosacáridos y evaluación de la actividad prebiótica de estos últimos.

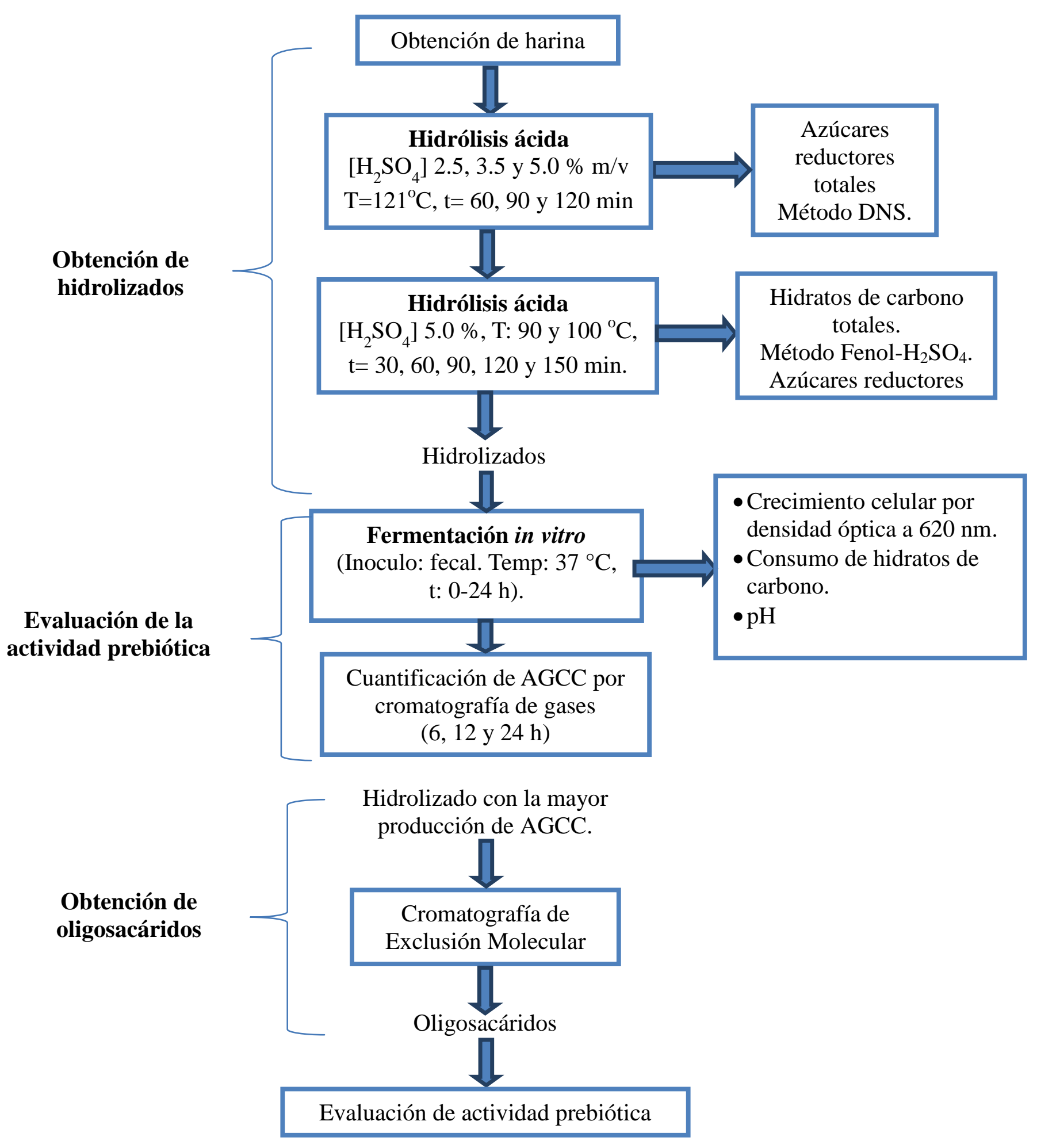

Figura 8. Metodología general de trabajo para obtener los hidrolizados y evaluar su actividad prebiótica. 


\subsection{Obtención de harina}

El tallo de la planta de amaranto se sometió a un proceso de secado en estufa a $50{ }^{\circ} \mathrm{C}$ durante $24 \mathrm{~h}$, el producto obtenido fue molido en un procesador de alimentos Hamilton Beach 70580, y tamizado en MONTINOX 0165 con una abertura de malla de 420 micrones (malla No. 40). La muestra fue colocada en un frasco y almacenada en un área seca, en ausencia de luz, hasta su uso. 


\subsection{Obtención de hidrolizados}

\subsubsection{Hidrólisis ácida primer experimento}

Los hidrolizados del tallo de la planta de amaranto fueron obtenidos químicamente por hidrólisis ácida mediante el Método de Conde (2009). Cada experimento se realizó por triplicado. La harina de tallo de amaranto se colocó en tubos de ensaye con tapón de rosca, se le adicionó ácido sulfúrico a las concentraciones de 2.5, 3.5 y $5.0 \%$ m/v en una relación 1:16 p/v, se colocaron en autoclave manteniendo condiciones isotérmicas de $121^{\circ} \mathrm{C}$ con presión de $15 \mathrm{lb} / \mathrm{pg}$, durante 60, 90 y 120 min para cada concentración de ácido. Posteriormente se filtraron y neutralizaron $(\mathrm{pH} 7)$ con solución de $\mathrm{NaOH} 4 \mathrm{M}$ utilizando un potenciómetro CONDUCTRONIC pH120 con electrodo combinado S200C, a continuación los hidrolizados se centrifugaron a $5000 \mathrm{rpm}$ en un equipo SIGMA $2 \mathrm{~K}-15$ por $10 \mathrm{~min}$, finalmente se almacenaron a $4{ }^{\circ} \mathrm{C}$. Se cuantificó en el sobrenadante el contenido de azúcares reductores totales expresados como mg xilosa por g de tallo. Se construyó el gráfico [azúcares reductores totales] vs tiempo de hidrólisis, para cada concentración de ácido, para elegir la concentración de ácido con la cinética de hidrólisis más corta.

\subsubsection{Cuantificación de azúcares reductores}

Para medir el grado de hidrólisis se cuantificó el contenido de azúcares reductores totales por el método del ácido 3,5-dinitrosalicílico (DNS) (Miller, 1959) en los hidrolizados del tallo de amaranto. El reactivo de DNS se preparó mezclando $1 \mathrm{~g}$ de 3,5dinitrosalicílico, $1 \mathrm{~g}$ de $\mathrm{NaOH}, 0.05 \mathrm{~g}$ de $\mathrm{Na}_{2} \mathrm{SO}_{3}$ anhídro, $0.2 \mathrm{~g}$ de cristales de fenol en $100 \mathrm{~mL}$ de agua destilada y se almacenó en frasco ámbar bajo refrigeración. Para la determinación de azúcares reductores se mezcló $1 \mathrm{~mL}$ del reactivo de DNS con $1 \mathrm{~mL}$ de disolución de muestra, se agitó en vortex por 30 s y se llevó a ebullición por 5 min en baño maría. A continuación se enfrió a temperatura ambiente, se adicionaron $10 \mathrm{~mL}$ de agua destilada y se dejó reposar 15 min. Posteriormente se medió la absorbancia a 540 $\mathrm{nm}$ en un espectrofotómetro GENESYS 10uv. El contenido de azúcares reductores totales en los hidrolizados se calculó mediante una curva patrón cuyo rango de concentración fue de 0.4-2.0 mg de xilosa/mL. 


\subsubsection{Hidrólisis ácida segundo experimento}

A una concentración constante de $\mathrm{H}_{2} \mathrm{SO}_{4}$ se realizó un segundo experimento de hidrólisis ácida, en donde se obtuvieron hidrolizados a las temperaturas de 90 y $100{ }^{\circ} \mathrm{C}$ y a los tiempos de 30, 60, 90, 120 y $150 \mathrm{~min}$. Transcurridas las condiciones de hidrólisis, los hidrolizados fueron colocados inmediatamente en un baño de hielo, posteriormente se filtraron, neutralizaron, centrifugaron y finalmente se evaporó su contenido de agua en la liofilizadora SCIENTZ-18N. A las muestras una vez secas se les determinó el contenido de hidratos de carbono totales por el Método de Fenol$\mathrm{H}_{2} \mathrm{SO}_{4}$.

\subsubsection{Cuantificación de hidratos de carbono totales}

Esta determinación se realizó a través de la técnica de Fenol-sulfúrico (Dubois et al., 1956), en la que a partir de cada hidrolizado se prepararon disoluciones en agua, para tomar un volumen de $200 \mu \mathrm{L}$ y colocar en un tubo al que se le adicionaron $120 \mu \mathrm{L}$ de fenol al $5 \%$ y $720 \mu \mathrm{L}$ de ácido sulfúrico concentrado lentamente por la pared. Se agitó con cuidado y dejó enfriar aproximadamente $30 \mathrm{~min}$ a temperatura ambiente, y posteriormente se determinó la absorbancia de las muestras a $480 \mathrm{~nm}$. El contenido de hidratos de carbono totales de los hidrolizados se determinó mediante el uso de una curva patrón cuyo rango de concentración fue de 10-100 $\mu$ g glucosa/mL. 


\subsection{Evaluación de la actividad prebiótica}

\subsubsection{Fermentación in vitro}

Para evaluar la actividad prebiótica de los hidrolizados obtenidos a las temperaturas de 90 y $100{ }^{\circ} \mathrm{C}$ durante los tiempos de hidrólisis de 30, 60, 90, 120 y 150 minutos se realizaron las fermentaciones in vitro utilizando un inoculo fecal. Viales de $14 \mathrm{~mL}$ de capacidad fueron llenados con $4.5 \mathrm{~mL}$ de medio de cultivo estéril basal que incluyó de acuerdo con Campos-Vega et al. (2009) (g/L): agua peptonada 2, extracto de levadura 2, $\mathrm{NaCl} 0.1, \mathrm{~K}_{2} \mathrm{HPO}_{4} 0.04, \mathrm{KH}_{2} \mathrm{PO}_{4} 0.04, \mathrm{MgSO}_{4} .7 \mathrm{H}_{2} \mathrm{O} 0.01, \mathrm{CaCl}_{2} .2 \mathrm{H}_{2} \mathrm{O} 0.01, \mathrm{NaHCO}_{3}$ 2, cisteína- $\mathrm{HCl} 0.5$, sales biliares 0.5 , tween $802 \mathrm{~mL}$ y $15 \mathrm{mg}$ de hidratos de carbono totales presentes en los hidrolizados. Inulina y pectina se utilizaron como controles, y se manipularon bajo las mismas condiciones que las muestras. Dos replicas se utilizaron para cada tiempo de fermentación de cada sustrato. Se colocaron los tapones de hule a los viales y enseguida fueron cerrados con sellos de aluminio, posteriormente los medios de cultivo se esterilizaron a $118^{\circ} \mathrm{C}$ por $10 \mathrm{~min}$. El inoculo se preparó a partir de una muestra donada por un adulto sano, que ingirió una dieta normal, no consumió antibióticos tres meses previos al experimento y no tuvo historial de padecimientos intestinales, $2 \mathrm{~g}$ de heces frescas se mezclaron con $18 \mathrm{~mL}$ de buffer de fosfato de sodio $0.1 \mathrm{M}$, pH 7 a $37{ }^{\circ} \mathrm{C}$ (Campos-Vega et al., 2009), se filtraron a través de seis gasas y un volumen de $0.5 \mathrm{~mL}$ se adicionó con una jeringa a cada vial, posteriormente el oxígeno fue desplazado por $\mathrm{CO}_{2}$ (Barry et al., 1995). Antes de colocar las muestras ya inoculadas en incubación se realizó el muestreo correspondiente al tiempo 0 h. Las muestras se colocaron en un baño de agua a $37^{\circ} \mathrm{C}$ con agitación en un equipo LABLINE 3582.

Para determinar el crecimiento celular mediante densidad óptica a los tiempos de $0,2,4$, $6,8,10$ y $24 \mathrm{~h}$ se colectaron dos viales de cada tiempo y muestra para leer su absorbancia a $620 \mathrm{~nm}$. Para estos tiempos también se determinó su pH para construir el perfil de acidificación de la fermentación de cada muestra. Las muestras obtenidas a los tiempos de 0, 6, 10 y $24 \mathrm{~h}$ se centrifugaron a $10000 \mathrm{rpm}$ por $5 \mathrm{~min}$ y se analizó en el sobrenadante el contenido de hidratos de carbono totales por Fenol- $\mathrm{H}_{2} \mathrm{SO}_{4}$ para determinar el rendimiento biomasa-sustrato $(\mathrm{Yx} / \mathrm{s})$ y el contenido de ácidos grasos de cadena corta por cromatografía de gases para evaluar la capacidad prebiótica de las muestras.

El rendimiento biomasa-sustrato (Yx/s) se calculó mediante la siguiente expresión: 


$$
Y(x / s)=\frac{\Delta X}{\Delta S}=\frac{X-X o}{S o-S}
$$

Donde, $\mathrm{Y}(\mathrm{x} / \mathrm{s})$ es el rendimiento celular, $\Delta \mathrm{X}$ es la biomasa producida y $\Delta \mathrm{S}$ el sustrato consumido. X y Xo son la biomasa al final y al inicio del cultivo en $\mathrm{kg}$. S y So son el contenido de hidratos de carbono totales al final e inicio del cultivo en $\mathrm{kg}$.

\subsubsection{Cuantificación de ácidos grasos de cadena corta}

Para realizar la esterificación de los ácidos grasos de cadena corta, una alícuota de $2 \mathrm{~mL}$ de sobrenadante de los tiempos de fermentación de 6, 10 y 24 h de cada hidrolizado, se colocaron en tubos con tapón de rosca, y se le adicionó $1 \mathrm{~mL}$ de $\mathrm{HCl} 10 \%$ en etanol y $100 \mu \mathrm{L}$ de catalizador $\mathrm{BF}_{3}$. Inmediatamente fueron colocados en baño maría a $80^{\circ} \mathrm{C}$ por 60 min, transcurrido ese tiempo se enfriaron y se realizó la extracción de los ésteres por duplicado con $0.75 \mathrm{~mL}$ de cloroformo. Los extractos orgánicos se secaron con sulfato de sodio anhidro, se hicieron pasar a través de un filtro de $0.45 \mu$ y se almacenaron a $-20{ }^{\circ} \mathrm{C}$. Los ésteres etílicos de los ácidos acético, propiónico y butírico fueron cuantificados por cromatografía de gases (CG) utilizando un equipo HP 6890 acoplado a un detector de ionización de flama, con una columna capilar SUPELCOWAX-10 de $30 \mathrm{~m}$ de longitud, $0.25 \mathrm{~mm}$ de diámetro interno y espesor de película de $0.25 \mu \mathrm{m}$. Se utilizó el método cromatográfico de acuerdo con Lebet et al. (1998), con modificaciones en el flujo de la fase móvil y la temperatura de la columna: nitrógeno como gas acarreador (1.5 mL/min), Split 30, temperatura del inyector, del horno y del detector de 250, 90 y $250{ }^{\circ} \mathrm{C}$ respectivamente. El volumen de inyección fue de $0.5 \mu \mathrm{L}$. Se determinaron los tiempos de retención. El análisis cuantitativo se realizó a partir de las curvas de calibración construidas, esterificando los estándares ácido acético, propiónico y butírico en los rangos de concentración de $0.57-11.36,0.049-4.90$ y $0.043-4.30$ $\mathrm{mmol} / \mathrm{L}$. respectivamente. 


\subsection{Obtención de oligosacáridos}

\subsubsection{Cromatografía de filtración en gel}

Para separar los oligosacáridos se realizó una cromatografía de filtración en Sephadex G-25, cuyo tamaño de partícula es de 50-150 $\mu$ e intervalo de separación de 1-5kDa (John et al., 1969), utilizando agua desionizada a $65{ }^{\circ} \mathrm{C}$ como eluyente (Schmidt y Enevoldsen, 1976; John et al., 1982). Cada fracción se capturó por un tiempo de 4min en tubos de ensaye mediante el colector de fracciones BIO-RAD 2110, en la primera corrida se utilizaron 40 tubos y dado que a partir del tubo 16 no se observó presencia de hidratos de carbono, se acorto el número de fracciones a 20. Los cromatogramas de los estándares dextrano y glucosa, así como del hidrolizado, se construyeron mediante la determinación de hidratos de carbono totales por el método Fenol- $\mathrm{H}_{2} \mathrm{SO}_{4}$ a cada una de las fracciones (eje de las ordenadas) vs tiempo (eje de las abscisas). A partir de la elución del hidrolizado se separaron las fracciones con similar tiempo de elución al estándar de hexosa, posteriormente se evaporó su contenido de agua mediante liofilización para someterlos a continuación a fermentación in vitro. 


\subsection{Diseño experimental y análisis estadístico}

El desarrolló experimental se llevó a cabo mediante un diseño con arreglo factorial al crearse 10 tratamientos distintos con todas las combinaciones de los dos niveles de Temperatura: 90 y $100{ }^{\circ} \mathrm{C}$ con los cinco niveles de tiempo de hidrólisis: 30, 60, 90, 120 y 150 min. El modelo que se utilizó fue:

$Y_{i j k}=\mu+T_{i}+t_{j}+(T t)_{i j}+\varepsilon_{i j k}$

Donde $\mathrm{Y}_{\mathrm{ijk}}$ es la variable respuesta en la k-ésima repetición a la que se aplicó el i-ésimo nivel de temperatura y el j-ésimo nivel de tiempo de hidrólisis. $\mu$ es la media general, $\mathrm{T}_{\mathrm{i}}$ es el efecto del i-ésimo nivel de temperatura, tj es el efecto del j-ésimo nivel de tiempo de hidrólisis, (Tt)ij es el efecto de tratamiento sobre la variable respuesta $\mathrm{y}, \varepsilon_{\mathrm{ijk}}$ es el error asociado a la observación $\mathrm{Y}_{\mathrm{ijk}}$.

Los resultados fueron analizados mediante un análisis de varianza (ANOVA), utilizando el programa SPSS para Windows Versión 17. La diferencia significativa $(\mathrm{p}<0.05)$ entre tratamientos se llevó a cabo mediante un análisis de medias de Tukey del mismo paquete estadístico. Los resultados obtenidos fueron expresados como media \pm desviación estándar.

Para comparar los resultados obtenidos respecto a otras publicaciones se realizaron pruebas de t de Student con un nivel de significancia de 0.05 . 


\section{RESULTADOS}

\subsection{Obtención de hidrolizados}

\subsubsection{Hidrólisis ácida primer experimento}

Los azúcares reductores totales promedio y su desviación estándar en las cinéticas de hidrólisis a las concentraciones de $\mathrm{H}_{2} \mathrm{SO}_{4}$ de $2.5,3.5$ y $5.0 \% \mathrm{~m} / \mathrm{v}$ se muestran en la Figura 9.

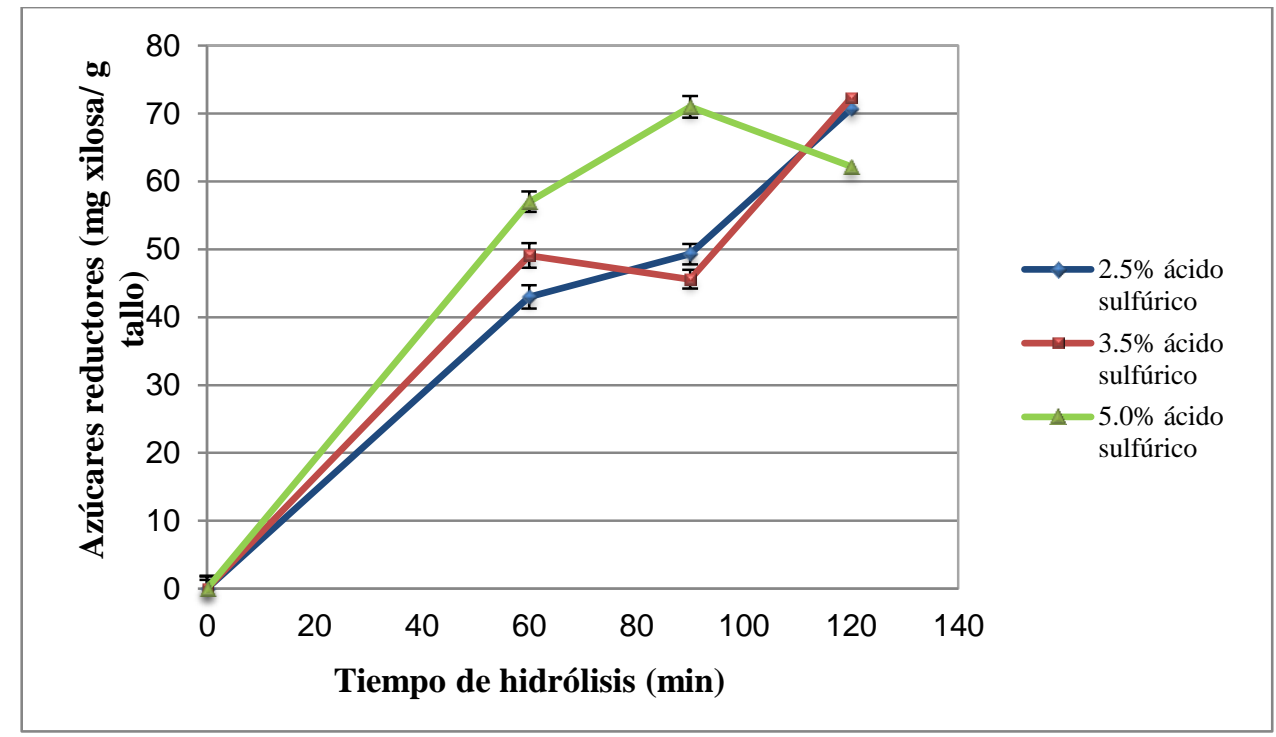

Figura 9. Cinética de hidrólisis obtenidas bajo las condiciones de concentración de ácido y tiempo de hidrólisis, analizadas a temperatura constante de $121^{\circ} \mathrm{C}$.

De acuerdo con la gráfica anterior a concentraciones de ácido sulfúrico de 2.5 y $3.5 \%$ se requieren tiempos mayores a 120 min para observar una hidrólisis completa, como a la concentración de 5.0 \% de ácido en donde se observó una cinética que se llevó a cabo en menos tiempo, a 90 min se obtuvo un máximo de azúcares reductores totales y a 120 min se aprecia que parte de los azúcares presentes en la muestra se han degradado. Las concentraciones de azúcares son distintas y en general mayores a concentraciones superiores de ácido (3.5 y $5.0 \%$ ) debido a que bajo estas condiciones se tiene una mayor concentración de protones para romper las uniones éter heterocíclicas entre los monómeros de azúcares de la cadenas poliméricas de la hemicelulosa y celulosa del material lignocelulósico del tallo de amaranto. Por lo tanto, a partir de este primer experimento se decide elegir la concentración de ácido de $5.0 \% \mathrm{~m} / \mathrm{v}$ para realizar el segundo experimento, en donde los factores a someter a prueba son la temperatura y el tiempo de hidrólisis para determinar las condiciones de hidrólisis que permitan obtener la mayor concentración de oligosacáridos. 


\subsubsection{Hidrólisis ácida segundo experimento}

El contenido de hidratos de carbono totales, de azúcares reductores totales y el porcentaje de éstos últimos se presenta en la Tabla 6 y corresponden a los hidrolizados obtenidos a las temperaturas de 90 y $100{ }^{\circ} \mathrm{C}$ en combinación con los tiempos de 30, 60, 90, 120 y 150 min a la concentración de $\mathrm{H}_{2} \mathrm{SO}_{4}$ de $5.0 \% \mathrm{~m} / \mathrm{v}$.

Tabla 6. Contenido de hidratos de carbono totales, azúcares reductores totales de las muestras, obtenidos en el segundo experimento de hidrólisis ácida.

\begin{tabular}{|c|cc|cc|cc|}
\hline \multirow{2}{*}{$\begin{array}{c}\text { Tiempo } \\
(\mathbf{m i n})\end{array}$} & \multicolumn{2}{|c|}{$\begin{array}{c}\text { Hidratos de carbono totales } \\
\text { (mg glucosa) }\end{array}$} & \multicolumn{2}{|c|}{$\begin{array}{c}\text { Azúcares reductores totales } \\
\text { (mg glucosa) }\end{array}$} & \multicolumn{2}{|c|}{$\%$ AR } \\
\cline { 2 - 7 } & $90^{\circ} \mathrm{C}$ & $100^{\circ} \mathrm{C}$ & $90^{\circ} \mathrm{C}$ & $100^{\circ} \mathrm{C}$ & $90^{\circ} \mathrm{C}$ & $100^{\circ} \mathrm{C}$ \\
\hline $\mathbf{3 0}$ & $35.2^{\mathrm{T}, \mathrm{a}} \pm 1.0$ & $31.2^{\mathrm{T}, \mathrm{a}} \pm 1.3$ & $22.6^{\mathrm{L}, \mathrm{h}} \pm 0.5$ & $16.2^{\mathrm{L}, \mathrm{h}} \pm 1.4$ & 64 & 52 \\
$\mathbf{6 0}$ & $46.0^{\mathrm{U}, \mathrm{b}} \pm 1.7$ & $34.2^{\mathrm{T}, \mathrm{a}} \pm 3.2$ & $34.0^{\mathrm{M}, \mathrm{i}} \pm 3.9$ & $31.6^{\mathrm{M}, \mathrm{i}} \pm 2.9$ & 74 & 92 \\
$\mathbf{9 0}$ & $60.2^{\mathrm{V}, \mathrm{c}} \pm 2.3$ & $73.0^{\mathrm{W}, \mathrm{d}} \pm 1.9$ & $48.6^{\mathrm{N}, \mathrm{j}} \pm 1.0$ & $56.0^{\mathrm{N}, \mathrm{j}} \pm 2.6$ & 81 & 77 \\
$\mathbf{1 2 0}$ & $70.0^{\mathrm{V}, \mathrm{c}} \pm 2.7$ & $106.2^{\mathrm{Y}, \mathrm{f}} \pm 5.6$ & $55.7^{\mathrm{N}, \mathrm{j}} \pm 1.7$ & $58.1^{\mathrm{N}, \mathrm{j}} \pm 4.5$ & 79 & 55 \\
$\mathbf{1 5 0}$ & $91.7^{\mathrm{X}, \mathrm{e}} \pm 1.8$ & $156.0^{\mathrm{Z}, \mathrm{g}} \pm 3.0$ & $73.3^{\mathrm{O}, \mathrm{k}} \pm 4.1$ & $83.6^{\mathrm{O}, \mathrm{k}} \pm 2.3$ & 80 & 53 \\
\hline
\end{tabular}

$\%$ AR: porcentaje de azúcares reductores totales respecto de los hidratos de carbono total.

Los resultados con el promedio de dos experimentos independientes \pm desviación estándar.

$\mathrm{T}, \mathrm{U}, \mathrm{V}, \mathrm{W}, \mathrm{X}, \mathrm{Y}, \mathrm{Z}$ Medias de hidratos de carbono en la misma columna para distintos tiempos de hidrólisis con letras distintas son diferentes ( $\mathrm{p}<0.05)$. a,b,c,d,e,f,g Medias de hidratos de carbono en la misma línea para las dos temperaturas con diferente letra minúscula son diferentes $(p<0.05)$. $\mathrm{L}, \mathrm{M}, \mathrm{N}, \mathrm{O}$ Medias de azúcares reductores totales en la misma columna para distintos tiempos de hidrólisis con letras distintas son diferentes $(\mathrm{p}<0.05)$. h,i,j,k Medias de azúcares reductores totales en la misma línea para las dos temperaturas con diferente letra minúscula son diferentes $(\mathrm{p}<0.05)$.

El contenido de hidratos de carbono totales de los hidrolizados obtenidos a la misma temperatura fue mayor conforme aumento el tiempo de hidrólisis. Al comparar las dos temperaturas podemos observar que solo las medias de azúcares totales de $30 \mathrm{~min}$ no muestran diferencia significativa. En general, se obtuvieron mayores cantidades de azúcares totales a $100{ }^{\circ} \mathrm{C}$. La liberación de azúcares reductores totales fue mayor conforme aumento el tiempo y temperatura de hidrólisis. De las dos temperaturas analizadas las medias de estos azúcares fueron mayores a $150 \mathrm{~min}$. Considerando el contenido de azúcares reductores totales respecto al total de hidratos de carbono, las distintas condiciones de hidrólisis dieron porcentajes de azúcares reductores totales que oscilaron entre 52-93\% y que nos indican que en ninguno de los tratamientos se llevó a cabo una hidrólisis completa de material lignocelulósico, por lo que es probable que no se hayan formado productos de degradación de pentosas y hexosas como furfural e HMF. 


\subsection{Evaluación de la actividad prebiótica. Fermentación in vitro}

\subsubsection{Cinética de crecimiento}

A continuación se muestran las curvas de crecimiento para las bacterias colónicas en anaerobiosis utilizando como fuente de carbono los hidrolizados obtenidos a $90{ }^{\circ} \mathrm{C}$.

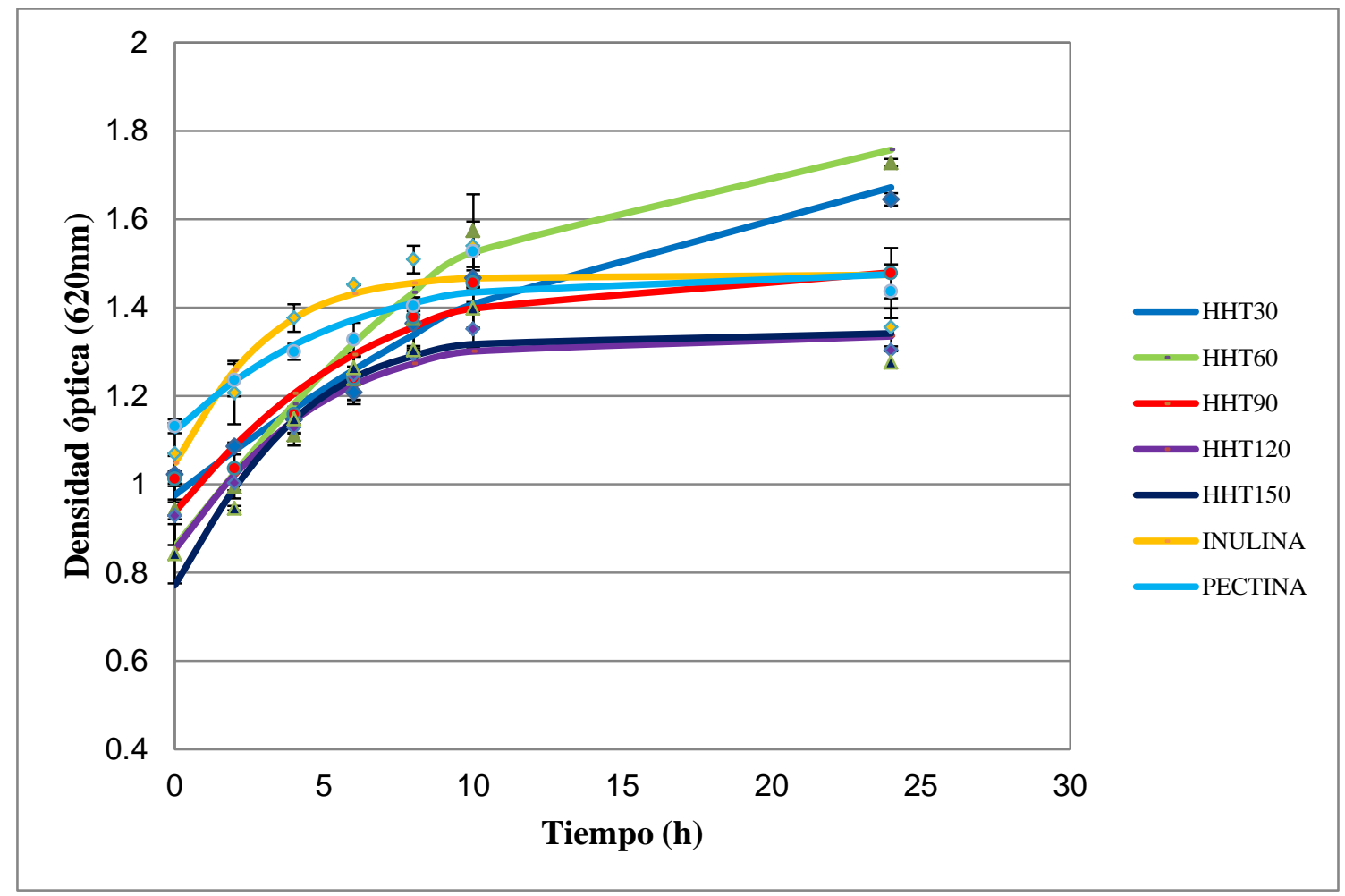

Figura 10. Cinéticas de crecimiento de la fermentación in vitro de los hidrolizados obtenidos a $90{ }^{\circ} \mathrm{C}$ por bacterias colónicas.

HHT: Hidrolizado de harina de tallo. El número corresponde al tiempo de hidrólisis en min.

Se presenta el crecimiento celular de las bacterias colónicas en la figura 10, donde es posible observar fases de adaptación (muy corta) y exponenciales comprendidas en tiempos menores a ocho horas en la mayoría de los casos. La fase estacionaria de las bacterias se presentó a partir de las diez horas con excepción de los hidrolizados obtenidos a los tiempos de 30 y 60 min que mostraron fases exponenciales de mayor duración, revelando el efecto del tiempo de hidrólisis sobre la capacidad de asimilación de la fuente de carbono por las bacterias pero que de seguir una cinética completa se necesitarían tiempos mayores a 24 horas. Las cinéticas de crecimiento fueron muy similares entre los hidrolizados obtenidos a 120 y 150 minutos, también los controles inulina y pectina que mostraron cinéticas de crecimiento muy semejantes entre sí. 
A continuación se presentan las curvas de crecimiento para las bacterias colónicas en anaerobiosis utilizando como fuente de carbono los hidrolizados obtenidos a $100{ }^{\circ} \mathrm{C}$.

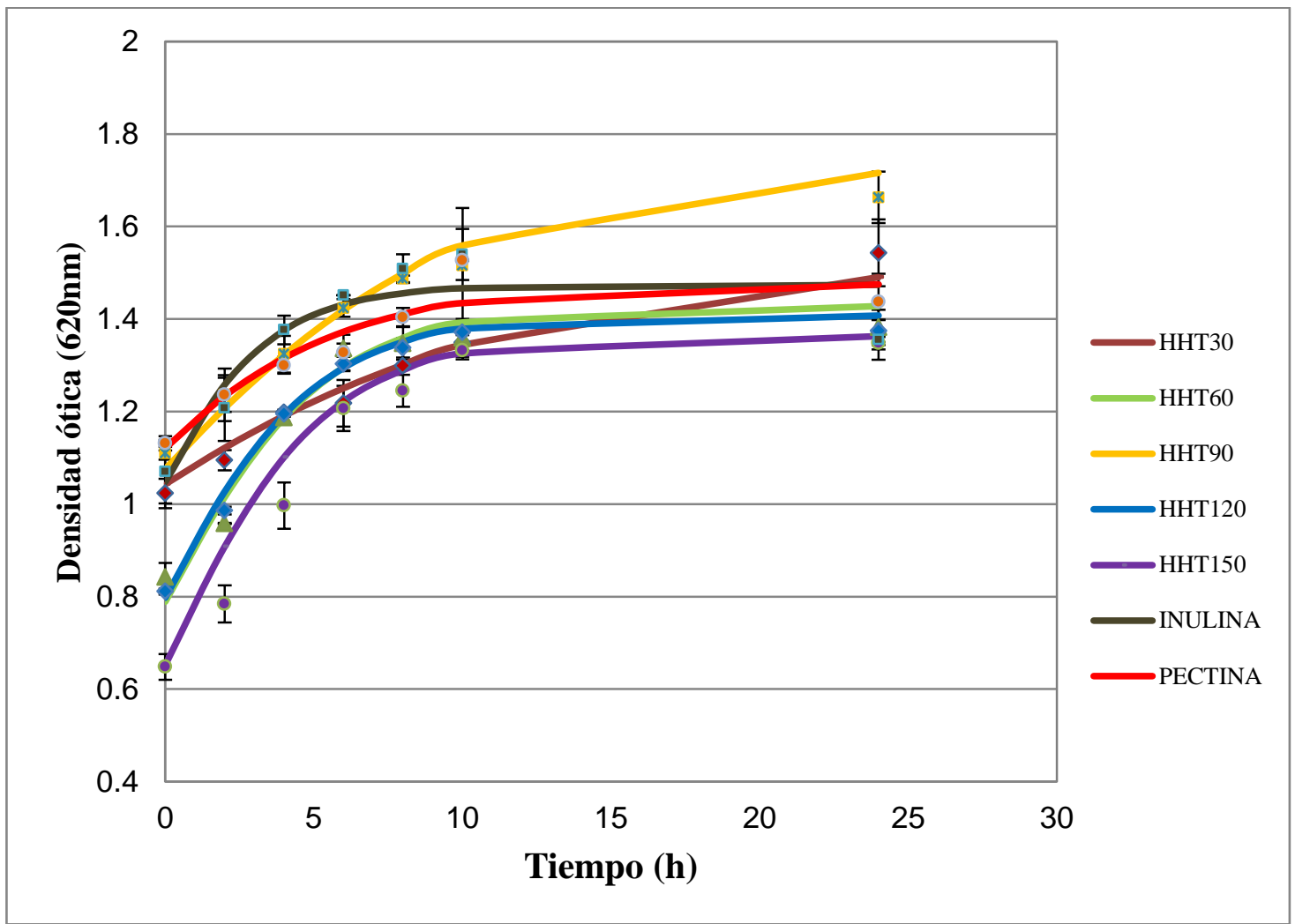

Figura 11. Cinéticas de crecimiento de la fermentación in vitro de los hidrolizados obtenidos a $100{ }^{\circ} \mathrm{C}$ por bacterias colónicas.

HHT: Hidrolizado de harina de tallo. El número corresponde al tiempo de hidrólisis en min.

Se pueden observar en las cinéticas de crecimiento de la Figura 11 diferencias en la cantidad de inoculo inicial, a pesar de que se puso especial atención en homogeneizar y colocar el mismo volumen de inoculo a las muestras. Las fases de adaptación y exponencial en las mayoría de los casos se encontraron entre las primeras ocho horas, con excepción de las fuentes de carbono obtenidas a 30 y 90 minutos. Las fases estacionarias de las bacterias colónicas se alcanzaron a cantidades similares de biomasa, a pesar de que la cantidad inicial de inoculo fue diferente, únicamente el hidrolizado obtenido a 90 minutos no presentó este comportamiento, ya que mostro una mayor densidad óptica que es deseable porque indica un mayor crecimiento y por ende una mayor capacidad de asimilación del sustrato. 


\subsubsection{Parámetros cinéticos}

A partir de las cinéticas de crecimiento ajustadas fue posible calcularlos parámetros de fermentación: velocidades específicas de crecimiento y tiempos de duplicación, estos resultados aparecen en la Tabla 7.

Tabla 7. Velocidad específica de crecimiento $(\mu)$ y tiempo de duplicación $(t d)$ de las bacterias colónicas en la fermentación de los hidrolizados.

\begin{tabular}{|c|c|c|c|c|}
\hline \multirow{2}{*}{ MUESTRA } & \multicolumn{2}{|c|}{$\begin{array}{l}\text { VELOCIDAD ESPECÍFICA DE } \\
\text { CRECIMIENTO }\left(\mu, h^{-1}\right)\end{array}$} & \multicolumn{2}{|c|}{$\begin{array}{c}\text { TIEMPO DE } \\
\text { DUPLICACIÓN }(t d, h)\end{array}$} \\
\hline & $90^{\circ} \mathrm{C}$ & $100^{\circ} \mathrm{C}$ & $90^{\circ} \mathrm{C}$ & $100^{\circ} \mathrm{C}$ \\
\hline $\mathrm{HHT}_{30}$ & $0.12^{\mathrm{W}, \mathrm{a}} \pm 0.02$ & $0.13^{\mathrm{W}, \mathrm{a}} \pm 0.03$ & $5.8 \pm 0.1$ & $5.5 \pm 0.9$ \\
\hline HHT $_{60}$ & $0.19^{\mathrm{W}, \mathrm{a}} \pm 0.04$ & $0.35^{\mathrm{Y}, \mathrm{c}} \pm 0.02$ & $3.8 \pm 0.4$ & $2.0 \pm 0.01$ \\
\hline HHT $_{90}$ & $0.23^{\mathrm{W}, \mathrm{a}} \pm 0.07$ & $0.17^{\mathrm{W}, \mathrm{a}} \pm 0.03$ & $3.1 \pm 0.6$ & $4.1 \pm 0.07$ \\
\hline $\mathrm{HHT}_{120}$ & $0.30^{\mathrm{X}, \mathrm{c}} \pm 0.04$ & $0.36^{\mathrm{Y}, \mathrm{c}} \pm 0.01$ & $2.3 \pm 0.3$ & $1.9 \pm 0.04$ \\
\hline HHT $_{150}$ & $0.37^{\mathrm{Y}, \mathrm{d}} \pm 0.03$ & $0.35^{\mathrm{Y}, \mathrm{d}} \pm 0.03$ & $1.9 \pm 0.1$ & $2.0 \pm 0.2$ \\
\hline $\begin{array}{l}\text { INULINA } \\
\text { PECTINA }\end{array}$ & \multicolumn{2}{|c|}{$\begin{array}{l}0.43^{\mathrm{Y}} \pm 0.04 \\
0.24^{\mathrm{W}} \pm 0.02\end{array}$} & \multicolumn{2}{|c|}{$\begin{array}{l}1.6 \pm 0.1 \\
2.9 \pm 0.2\end{array}$} \\
\hline
\end{tabular}

Los resultados con el promedio de dos experimentos independientes \pm desviación estándar.

HHT: Hidrolizado de harina de tallo. El número en subíndice corresponde al tiempo de hidrólisis en min.

$\mathrm{W}, \mathrm{X}, \mathrm{Y}$, Medias de velocidad específica en la misma columna para distintos tiempos de hidrólisis con letras distintas son diferentes $(\mathrm{p}<0.05)$. a, b, c, d Medias de velocidad específica en la misma línea para las dos temperaturas con diferente letra minúscula son diferentes $(\mathrm{p}<0.05)$.

Las velocidades específicas de crecimiento que presentaron las bacterias colónicas utilizando los hidrolizados como sustrato, oscilaron entre 0.12 y $0.37 \mathrm{~h}^{-1}$, los valores menores se observaron en los hidrolizados obtenidos a $90{ }^{\circ} \mathrm{C}$ por los tiempos de $30,60 \mathrm{y}$ $90 \mathrm{~min}$, mientras que a $100{ }^{\circ} \mathrm{C}$ fueron los tiempos de 30 y $90 \mathrm{~min}$, y sus velocidades específicas de crecimiento no mostraron diferencia significativa respecto al control pectina. Las velocidades específicas mayores se obtuvieron en los hidrolizados obtenidos a $90^{\circ} \mathrm{C}$ por 120 y 150 min, y los obtenidos a $100^{\circ} \mathrm{C}$ en los tiempos de 60,120 y 150 minutos y no presentaron diferencia significativa respecto al control inulina.

Respecto a los tiempos de duplicación estos se encuentran en un rango entre 5.8 y 1.6 h, los mayores tiempos los presentaron los hidrolizados obtenidos a $30 \mathrm{~min}$ en ambas temperaturas y los tiempos más cortos se observaron en los hidrolizados con las mayores velocidades específicas de crecimiento y fueron iguales o inferiores a dos horas. 


\subsubsection{Consumo de hidratos de carbono}

La Tabla 8 contiene los resultados correspondientes al consumo de los hidratos de carbono presentes en el medio de cultivo que fueron de $15 \mathrm{mg}$ provenientes de la hidrólisis del material lignocelulósico del rastrojo de amaranto.

Tabla 8. Consumo de hidratos de carbono (\%) por las bacterias colónicas durante la fermentación in vitro en anaerobiosis.

\begin{tabular}{|c|cc|}
\hline \multirow{2}{*}{ MUESTRA } & CONSUMO DE HIDRATOS DE CARBONO (\%) \\
\cline { 2 - 3 } & $\mathbf{9 0}^{\mathbf{o}} \mathbf{C}$ & $\mathbf{1 0 0}^{\mathbf{O}} \mathbf{C}$ \\
\hline $\mathrm{HHT}_{30}$ & $75.6^{\mathrm{W}, \mathrm{a}} \pm 3.1$ & $66.6^{\mathrm{W}, \mathrm{a}} \pm 1.4$ \\
$\mathrm{HHT}_{60}$ & $77.0^{\mathrm{W}, \mathrm{a}} \pm 3.3$ & $76.3^{\mathrm{W}, \mathrm{a}} \pm 1.0$ \\
$\mathrm{HHT}_{90}$ & $84.0^{\mathrm{X}, \mathrm{b}} \pm 4.7$ & $68.8^{\mathrm{W}, \mathrm{a}} \pm 3.8$ \\
$\mathrm{HHT}_{120}$ & $77.6^{\mathrm{W}, \mathrm{a}} \pm 3.9$ & $68.2^{\mathrm{W}, \mathrm{a}} \pm 3.8$ \\
$\mathrm{HHT}_{150}$ & $77.4^{\mathrm{W}, \mathrm{a}} \pm 0.2$ & $81.4^{\mathrm{W}, \mathrm{a}} \pm 1.0$ \\
\hline Inulina & \multicolumn{3}{|c|}{$\mathbf{9 6 . 4}^{\mathrm{X}} \pm \mathbf{1 . 0}$} \\
Pectina & \multicolumn{3}{|c|}{$\mathbf{9 2 . 8}^{\mathrm{X}} \pm \mathbf{0 . 2}$} \\
\hline
\end{tabular}

Los resultados con el promedio de dos experimentos independientes \pm desviación estándar.

HHT: Hidrolizado de harina de tallo. El número en subíndice corresponde al tiempo de hidrólisis en min.

$\mathrm{W}, \mathrm{X}$. Medias de consumo de hidratos de carbono en la misma columna para distintos tiempos de hidrólisis con letras distintas son diferentes $(\mathrm{p}<0.05)$. a, b. Medias de consumo de hidratos de carbono en la misma línea para las dos temperaturas con diferente letra minúscula son diferentes $(\mathrm{p}<0.05)$.

El consumo de hidratos de carbono en porcentaje fue mayor para los controles inulina y pectina, estos se adicionaron al medio de cultivo a la misma cantidad (15 mg) que las muestras. La utilización de hidratos de carbono presentes es los hidrolizados por las bacterias colónicas no fue completa ya que se observaron distintos consumos que oscilaron entre 66.6 y $84.0 \%$, este último porcentaje se presentó en el hidrolizado obtenido a $90{ }^{\circ} \mathrm{C}$ por 90 min y cuya media no presenta diferencia significativa $(\mathrm{p}<0.05)$ respecto a la media de los controles.

Como se mencionó anteriormente la inulina es un extracto puro soluble, no ramificado y dada esta estructura se fermenta más fácilmente por las bacterias, con ello se explica su rápido consumo y el bajo $\mathrm{pH}$ que se puede apreciar enseguida en los perfiles de acidificación. 


\subsubsection{Rendimiento biomasa-sustrato}

En la Tabla 9 aparecen los rendimientos biomasa-sustrato (Yx/s) observados durante las cinéticas de crecimiento de las bacterias colónicas en la fermentación de los hidrolizados obtenidos a 90 y $100{ }^{\circ} \mathrm{C}$.

Tabla 9. Rendimientos biomasa-sustrato ( $\mathrm{Y} \mathbf{x} / \mathbf{s})$ para las cinéticas de crecimiento de los hidrolizados obtenidos a 90 y $100{ }^{\circ} \mathrm{C}$.

\begin{tabular}{|c|cc|}
\hline \multirow{2}{*}{ MUESTRA } & \multicolumn{2}{|c|}{ RENDIMIENTO BIOMASA-SUSTRATO (Yx/s) } \\
\cline { 2 - 3 } & $\mathbf{9 0} \mathbf{~} \mathbf{C}$ & $\mathbf{1 0 0}^{\mathbf{o}} \mathbf{C}$ \\
\hline $\mathrm{HHT}_{30}$ & $0.54^{\mathrm{X}, \mathrm{a}} \pm 0.09$ & $0.50^{\mathrm{X}, \mathrm{a}} \pm 0.14$ \\
$\mathrm{HHT}_{60}$ & $0.63^{\mathrm{Y}, \mathrm{a}} \pm 0.03$ & $0.68^{\mathrm{Y}, \mathrm{a}} \pm 0.09$ \\
$\mathrm{HHT}_{90}$ & $0.32^{\mathrm{W}, \mathrm{b}} \pm 0.08$ & $0.37^{\mathrm{W}, \mathrm{b}} \pm 0.08$ \\
$\mathrm{HHT}_{120}$ & $0.40^{\mathrm{W}, \mathrm{b}} \pm 0.01$ & $0.36^{\mathrm{W}, \mathrm{b}} \pm 0.01$ \\
$\mathrm{HHT}_{150}$ & $0.38^{\mathrm{W}, \mathrm{b}} \pm 0.01$ & $0.36^{\mathrm{W}, \mathrm{b}} \pm 0.01$ \\
\hline Inulina & & $0.28^{\mathrm{W}} \pm 0.01$ \\
Pectina & & $0.24^{\mathrm{W}} \pm 0.07$ \\
\hline
\end{tabular}

Los resultados son el promedio de dos experimentos independientes \pm desviación estándar. HHT: Hidrolizado de harina de tallo. El número indica el tiempo de hidrólisis en min.

$\mathrm{W}, \mathrm{X}, \mathrm{Y}$ Medias de rendimiento biomasa-sustrato en la misma columna para distintos tiempos de hidrólisis con letras distintas son diferentes $(\mathrm{p}<0.05)$.

$\mathrm{a}, \mathrm{b}$, Medias de rendimiento biomasa-sustrato en la misma línea para las dos temperaturas con diferente letra minúscula son diferentes $(\mathrm{p}<0.05)$.

Los rendimientos biomasa-sustrato, respecto al consumo de hidratos de carbono totales presentes en el medio de cultivo provenientes de los hidrolizados oscilaron entre $0.32 \mathrm{y}$ 0.63 para los hidrolizados obtenidos a $90{ }^{\circ} \mathrm{C}$, para esta misma temperatura los tiempos de 30 y 60 min mostraron medias significativamente mayores a los tiempos de 90,120 y 150 min, comportamiento que fue observado en las muestras de $100{ }^{\circ} \mathrm{C}$. Los controles inulina y pectina dieron medias que no mostraron diferencia significativa con los menores rendimientos. Comparando las dos temperaturas, los hidrolizados obtenidos a 60 min mostraron los rendimientos biomasa-sustrato significativamente mayores, lo que puede deberse a que los hidratos de carbono presentes posiblemente tienen estructuras químicas, tipos de enlaces entre sus unidades, y uniones a otras moléculas que no son hidratos de carbono (Swennen et al., 2006) que permite que sean metabolizados en mayor grado por las enzimas hidroliticas de las bacterias colónicas y favorezcan su crecimiento. 


\subsubsection{Perfiles de acidificación}

Los cambios de $\mathrm{pH}$ observados a los largo de la fermentación debidos al consumo de hidratos de carbono de los hidrolizados obtenidos a $90^{\circ} \mathrm{C}$ por las bacterias colónicas se muestran en la Figura 12.

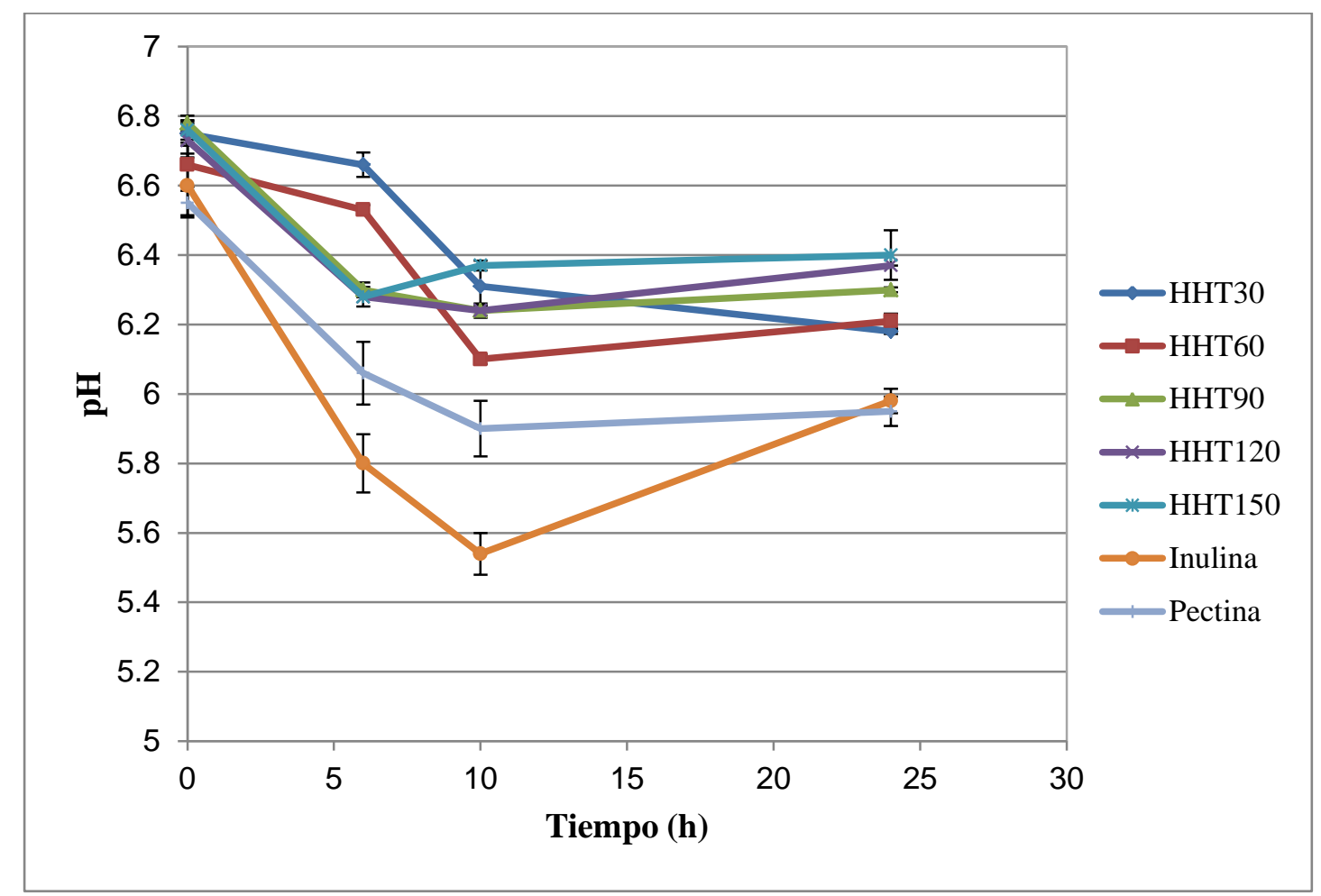

Figura 12. Cambio de pH durante la fermentación in vitro de los hidrolizados obtenidos a $90^{\circ} \mathrm{C}$.

HHT: Hidrolizado de harina de tallo. El número indica el tiempo de hidrólisis en min.

Los valores son medias de dos repeticiones: errores estándar de las medias son mostrados por las barras verticales.

Durante la fermentación que duró $24 \mathrm{~h}$ el cambio de $\mathrm{pH}$ en cada una de las muestras fue distinto. El descenso de $\mathrm{pH}$ para los controles pectina e inulina fue de 6.8-6.0 y de 6.85.9, respectivamente, esta diminución fue mayor para la inulina a las $10 \mathrm{~h}, \mathrm{pH}$ fue de 5.5, el más bajo de todas las muestras, en cuanto a la pectina su valor se mantuvo constante a partir de las $10 \mathrm{~h}$.

El cambio de $\mathrm{pH}$ fue similar entre los hidrolizados obtenidos a 90, 120 y 150 min que fue de 6.8 a 6.4. El hidrolizado que mostro la disminución de $\mathrm{pH}$ mayor fue el de $60 \mathrm{~min}$ a las $10 \mathrm{~h}$ de iniciada la fermentación y al final de la misma tuvo un $\mathrm{pH}$ semejante a los demás hidrolizados. 
Los cambios de $\mathrm{pH}$ observados durante la fermentación de los hidratos de carbono presentes en los hidrolizados obtenidos a $100{ }^{\circ} \mathrm{C}$ por las bacterias colónicas se aparecen en la Figura 13.

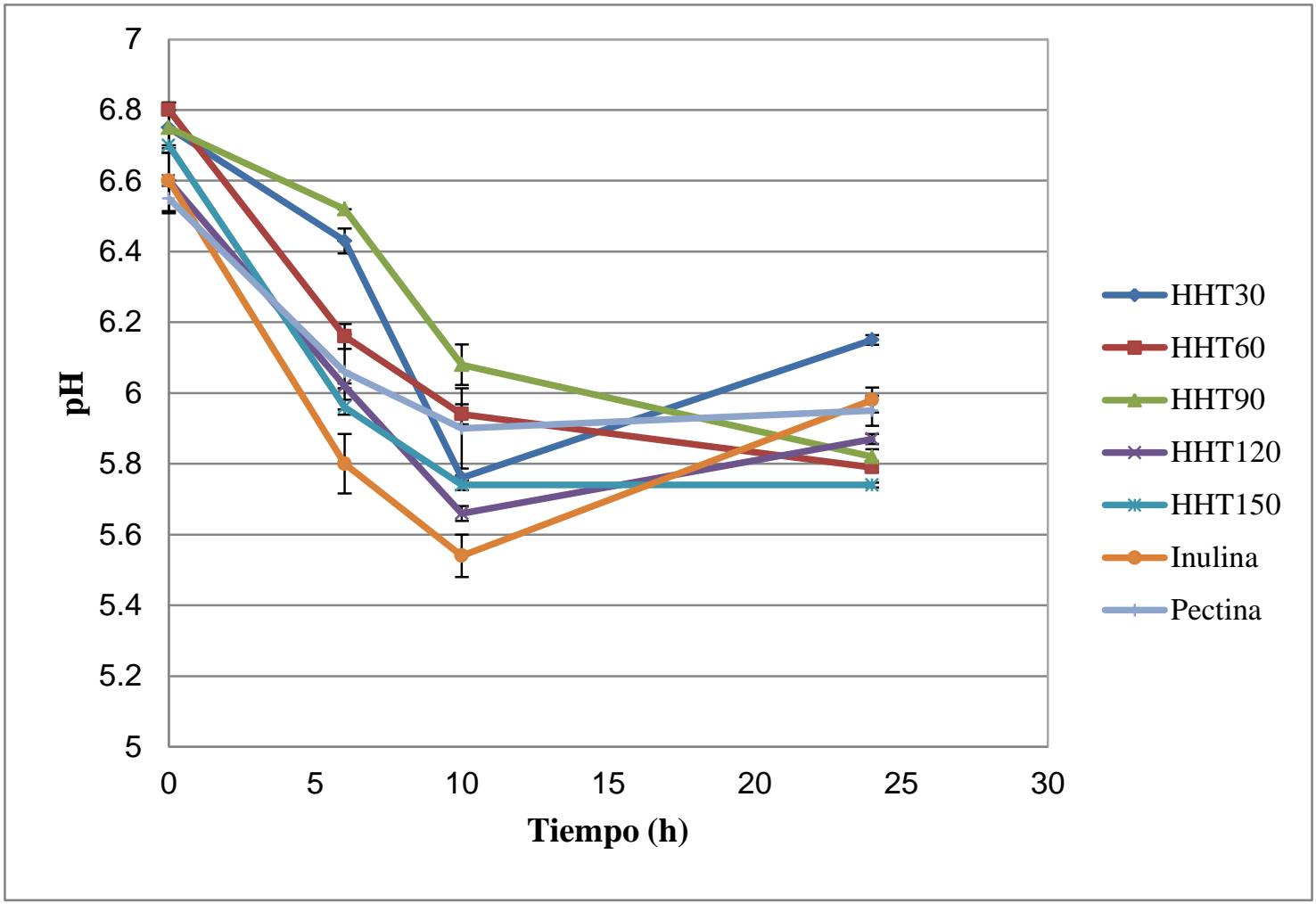

Figura 13. Cambio de pH durante la fermentación in vitro de los hidrolizados obtenidos a $100{ }^{\circ} \mathrm{C}$.

HHT: Hidrolizado de harina de tallo. El número indica el tiempo de hidrólisis en min.

Los valores son medias de dos repeticiones: errores estándar de las medias son mostrados por las barras verticales.

En este perfil de acidificación es posible observar que los hidrolizados mostraron un descenso de $\mathrm{pH}$ mayor que los hidrolizados obtenidos a $90^{\circ} \mathrm{C}$. Los mayores cambios de pH se observaron en el control inulina, sin embargo muestras como los hidrolizados a obtenidos a 120 y 150 min mostraron comportamientos similares. El pH a las $24 \mathrm{~h}$ para la mayoría de las muestras se encontró entre 5.7 y 6.0 unidades de pH, con excepción del hidrolizado obtenido a los 30 min cuyo pH a aumentó a 6.1.

Considerando otras publicaciones en donde realizaron trabajos similares tenemos que Karppinen et al., (2000), llevaron a cabo la fermentación in vitro de polisacáridos de arroz, trigo y avena, empleando inulina como control, la fermentación fue realizada por 24 h, durante ese tiempo el pH disminuyo de 7.2 hasta 6.0-6.3 en la fermentación de las 
muestras, este cambio de $\mathrm{pH}$ no muestra diferencia significativa $(\mathrm{p}<0.05)$ respecto al observado en los hidrolizados obtenidos a $90{ }^{\circ} \mathrm{C}(6.8-6.2)$ y $100{ }^{\circ} \mathrm{C}(6.8-5.8)$, es importante considerar las diferencias estructuras, debido a que las muestras usadas por Karppinen son fibras formadas por arabinoxilanos y $\beta$-glucanos solubles, probablemente los hidratos de carbono presentes en nuestras muestras también tienen estructuras complejas. En el caso de la inulina el pH más bajo que obtuvieron fue de 5.4 a las 10 horas, valor que no presenta diferencia significativa $(\mathrm{p}<0.05)$ en relación al $\mathrm{pH}$ obtenido en nuestro sistema de fermentación para la misma muestra y el mismo tiempo $(\mathrm{pH} 5.5 \pm 0.2)$.

Resultados obtenidos durante la fermentación in vitro de fracciones pécticas por Gulfi et al., (2007) mostraron cambios de pH de 6.7-6.1 para la pectina de bajo contenido de ácido urónico, que era la muestra en estudio, una cambio de 6.7-6.4 para una pectina comercial de bajo metoxilo, de 6.7-6.2 observado durante la fermentación de arabinogalactano y de lactulosa de 6.7-6.1, estos últimos utilizados como controles. Sus resultados nos muestran cambios de $\mathrm{pH}$ bajos, y su cambio de $\mathrm{pH}$ no muestra diferencia significativa $(\mathrm{p}<0.05)$ respecto al cambio de las fermentaciones de los hidrolizados obtenidos a $90{ }^{\circ} \mathrm{C}$ (6.8-6.2), por el contrario el cambio de $\mathrm{pH}$ de los hidrolizados obtenidos a $100{ }^{\circ} \mathrm{C}$ ( 6.8-5.8) si presentan un descenso de $\mathrm{pH}$ significativamente mayor $(\mathrm{p}<0.05)$.

Campos-Vega et al., (2009) realizaron la determinación de la composición química y evaluaron la fermentación in vitro de polisacáridos de diferentes variedades de frijol, a través del cambio de $\mathrm{pH}$ y la producción de AGCC. Las variedades analizadas y su descenso de $\mathrm{pH}$ fueron: Negro 8025 6.82-6.16, Bayo Madero 6.84-6.23, Pinto Durango 6.60-5.96, Azufrado Higuera 6.85-6.21 y el control Rafinosa 6.89-3.92 y respecto a los descensos de $\mathrm{pH}$ observados en los hidrolizados obtenidos en las dos temperaturas y tiempos de hidrólisis no presentaron diferencias significativa $\left(90{ }^{\circ} \mathrm{C}\right.$ : $6.8-6.2$ y $100{ }^{\circ} \mathrm{C}$ : 6.8-5.8). Al comparar el control rafinosa los hidrolizados presentaron descenso de $\mathrm{pH}$ significativamente menores.

Barry et al., (1995) realizaron una estimación de la fermentabilidad in vitro de cuatro fuentes de fibra dietética, el cambio de $\mathrm{pH}$ observado fue de celulosa 7.2-7.15, fibra de remolacha azucarera 7.2-6.6, fibra de soya 7.2-7.1 y salvado de maíz 7.2-6.8. Comparando el descenso de $\mathrm{pH}$ de los hidrolizados obtenidos a $90{ }^{\circ} \mathrm{C}$ (6.8-6.2), este fue 
significativamente mayor al observado por la celulosa, fibra de soya y salvado de maíz, y comparando los hidrolizados con la melaza de caña no presento diferencia significativa. Respecto a los hidrolizados de $100^{\circ} \mathrm{C}$, el cambio de $\mathrm{pH}$ (6.8-5.8) fue significativamente mayor al observado en celulosa y fibra de soya, y no mostro diferencia significativa respecto al cambio de salvado de maíz y melaza de caña. El descenso de $\mathrm{pH}$ de la pectina (7.2-6.3) analizada por el sistema de Barry fue similar al observado en el sistema de fermentación evaluado en el presente trabajo (6.7-5.7).

La disminución de $\mathrm{pH}$ durante la fermentación in vitro de las muestras por bacterias del colón se debe a la formación de ácidos orgánicos (Figura 14) principalmente por ácido láctico durante la fermentación de los hidratos de carbono presentes en las muestras, sin embargo este metabolito no fue cuantificado en el presente trabajo. De la transformación del piruvato a partir de la glucólisis de las hexosas o pentosas presentes en el medio por los sistemas enzimáticos de las bacterias colónicas, se generan ácidos como son: láctico, fórmico, acético, propiónico y butírico cuya presencia depende del tipo de microorganismo y de los aceptores finales de electrones.

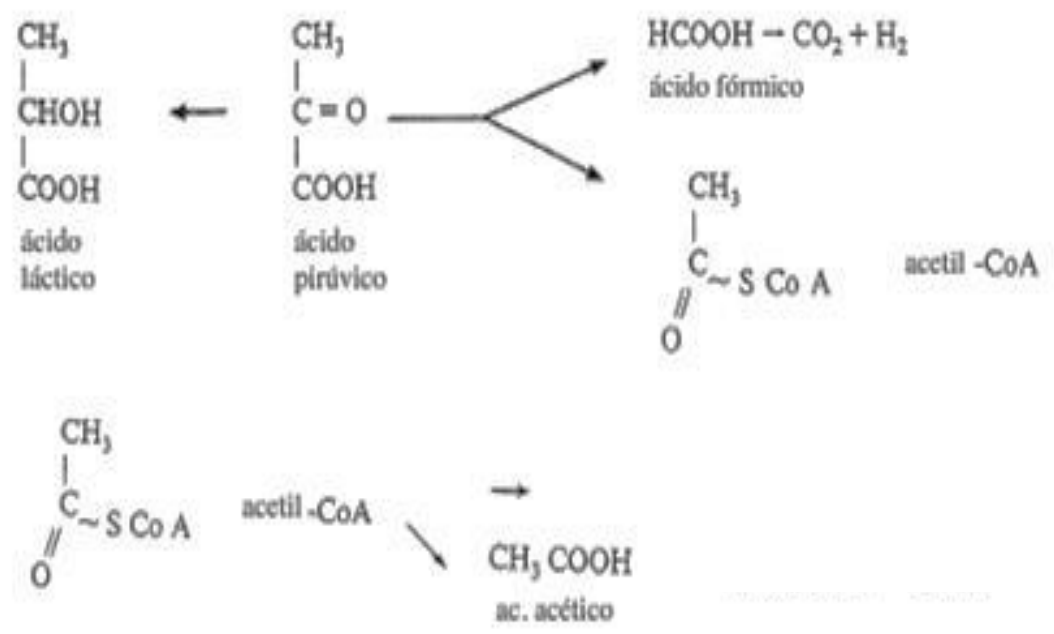

\section{Figura 14. Ejemplo de ácidos orgánicos responsables del descenso de pH en el medio de cultivo.}

A continuación se presentan los resultados de las concentraciones de ácidos grasos de cadena corta, acético, propiónico y butírico. 


\subsection{6 Ácidos grasos de cadena corta}

Los resultados de la producción de AGCC durante la fermentación de los azúcares en los hidrolizados obtenidos a $90^{\circ} \mathrm{C}$ por bacterias colónicas, se muestran en la Figura 15.

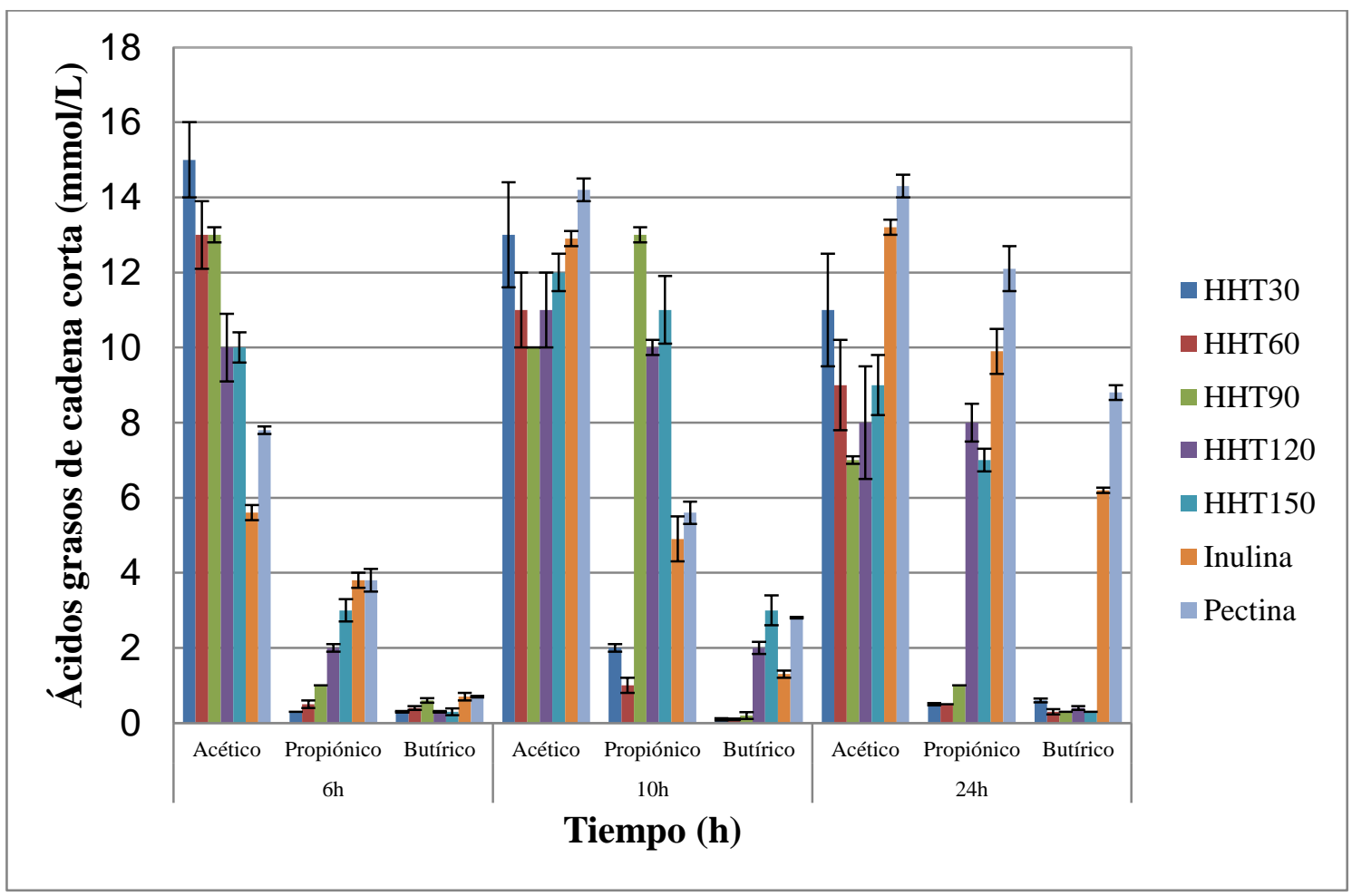

Figura 15. Concentración de ácidos grasos acético, propiónico y butírico en $\mathrm{mmol} / \mathrm{L}$ formados durante la fermentación de los hidrolizados obtenidos a $90{ }^{\circ} \mathrm{C}$.

HHT: Hidrolizado de harina de tallo. El número indica el tiempo de hidrólisis en min. Los valores son medias de dos repeticiones: errores estándar de las medias son mostrados por las barras verticales.

A los tres tiempos en que se determinó la presencia de estos metabolitos el ácido acético se encontró en mayor proporción, seguido del propiónico y al final el butírico, a las $6 \mathrm{~h}$ todos los hidrolizados presentaron concentraciones $(10-15 \mathrm{mmol} / \mathrm{L})$ significativamente $(\mathrm{p}<0.05)$ mayores respecto a los controles $(5.6-7.8 \mathrm{mmol} / \mathrm{L}$ inulina y pectina), por el contrario a las $24 \mathrm{~h}$ los controles mostraron concentraciones totales de ácidos (29-35 $\mathrm{mmol} / \mathrm{L})$ significativamente $(\mathrm{p}<0.05)$ mayores a las obtenidas por los hidrolizados $(8.3$ $16 \mathrm{mmol} / \mathrm{L})$.

Las mayores cantidades de ácido propiónico obtenidas por los hidrolizados de 90, 120 y $150 \mathrm{~min}(13,10$ y $11 \mathrm{mmol} / \mathrm{L})$ se observaron a las $10 \mathrm{~h}$ y fueron significativamente superiores a las concentraciones producidas a partir de los controles $(4.9-5.6 \mathrm{mmol} / \mathrm{L})$. 
Los ácidos grasos de cadena corta: acético, propiónico y butírico formados durante la fermentación in vitro de los azúcares de los hidrolizados obtenidos a $100{ }^{\circ} \mathrm{C}$, se presentan en la Figura 16.

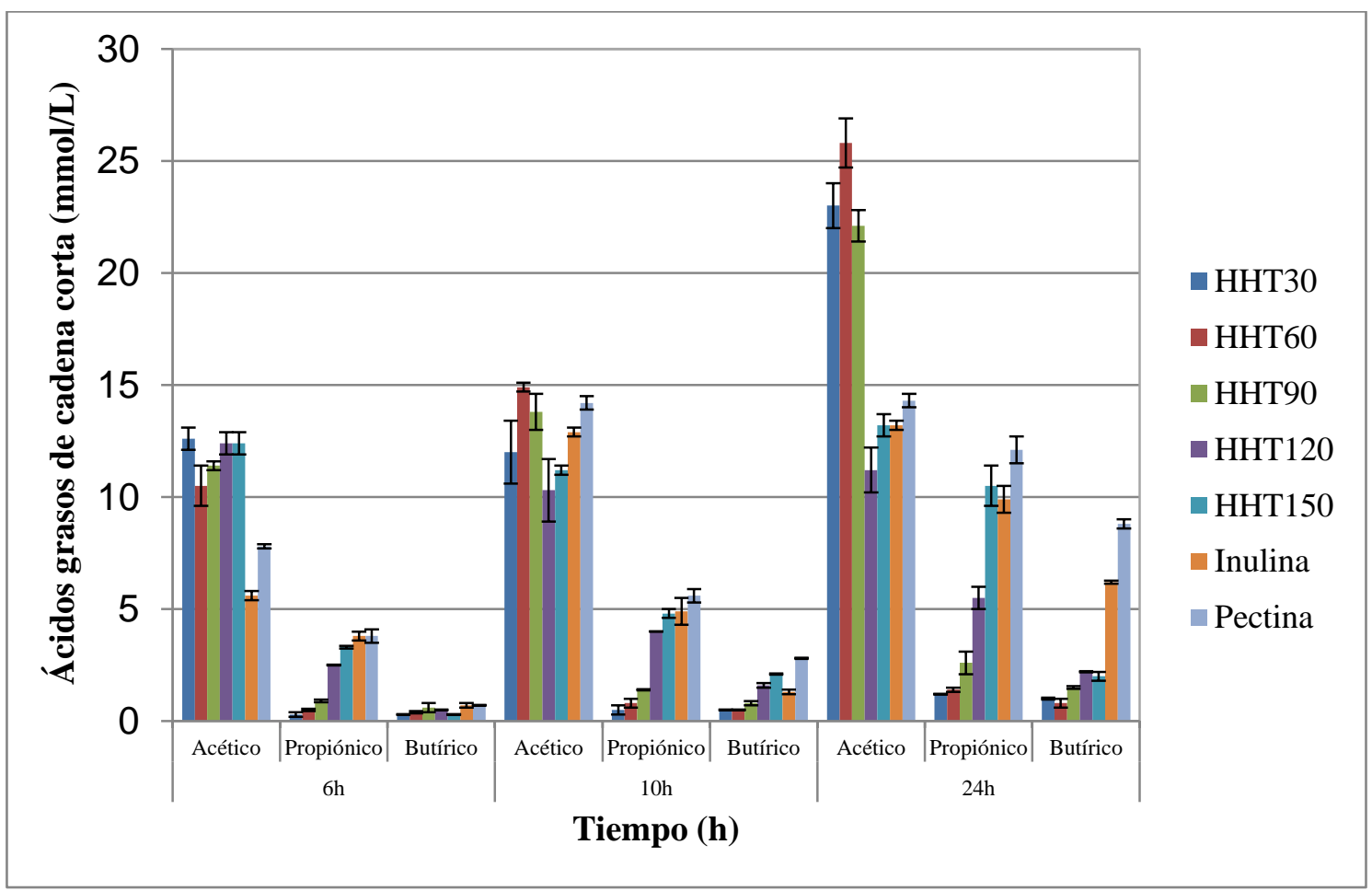

Figura 16. Concentración de ácidos grasos acético, propiónico y butírico en mmol/L formados durante la fermentación de los hidrolizados obtenidos a $100{ }^{\circ} \mathrm{C}$. HHT: Hidrolizado de harina de tallo. El número indica el tiempo de hidrólisis en min. Los valores son medias de dos repeticiones: errores estándar de las medias son mostrados por las barras verticales.

De la fermentación de los hidrolizados obtenidos a $100{ }^{\circ} \mathrm{C}$, se obtuvieron concentraciones de ácidos grasos mayores respecto a los observados a $90{ }^{\circ} \mathrm{C}$. Resultado esperado porque como se observó anteriormente el descenso de $\mathrm{pH}$ durante la fermentación de los hidrolizados obtenidos a $100{ }^{\circ} \mathrm{C}$ fue mayor. El ácido graso mayoritario fue el ácido acético seguido del propiónico y butírico. El ácido acético producido por la fermentación de los hidrolizados a las $6 \mathrm{~h}(10.5-12.6 \mathrm{mmol} / \mathrm{L})$ fue significativamente $(\mathrm{p}<0.05)$ mayor que los controles $(5.6,7.8 \mathrm{mmol} / \mathrm{L}$ para inulina $y$ pectina respectivamente), a las $10 \mathrm{~h}$ los hidrolizados obtenidos por 120 y $150 \mathrm{~min}$ (10.3 y $11.2 \mathrm{mmol} / \mathrm{L}$ ) no mostraron diferencia significativa en su producción de ácido acético respecto a los controles (inulina 12.9, pectina $14.2 \mathrm{mmol} / \mathrm{L}$ ). Las concentraciones de este ácido fueron superiores a las $24 \mathrm{~h}$ para los hidrolizados obtenidos en los tiempos de 
30,60 y $90 \mathrm{~min}$, fueron $23,25.8$ y $22.1 \mathrm{mmol} / \mathrm{L}$ y son significativamente mayores a los controles. La media de concentración de ácido propiónico producida por el hidrolizado obtenido a 150 min no mostró diferencia significativa respecto a la media de los controles a las $24 \mathrm{~h}$. Las cantidades de ácido butírico a las 10 y $24 \mathrm{~h}$ para los hidrolizados fueron significativamente $(\mathrm{p}<0.05)$ inferiores a las medias de los concentración de los controles.

Considerando los resultados de AGCC obtenidos por Karppinen (2000), en las fermentaciones de fibra de arroz, trigo y avena, usando inulina como control, el pH de las muestras a las $24 \mathrm{~h}$ fue de 6.0-6.3 y el contenidos de ácidos grasos para ese tiempo fue de 90, 91 y $100 \mathrm{mmol} / \mathrm{L}$ para el arroz, trigo y avena respectivamente. Obtuvieron estos resultados utilizando concentraciones de muestra de $100 \mathrm{mg}$. Analizando estas concentraciones de AGCC con los hidrolizados obtenidos a 90 y $100{ }^{\circ} \mathrm{C}$ podemos observar medias de producción que oscilaron entre $8.3-16.3$ y 11.3-28 mmol/L respectivamente, utilizando $15 \mathrm{mg}$ de carbohidratos totales, es probable que al utilizar una mayor cantidad de sustrato como Karppinen se obtuvieran también mayores cantidades de estos metabolitos. El control inulina usado por Karppinen a las 24 h tuvo una producción de $75 \mathrm{mmol} / \mathrm{L}$ de ácidos grasos, con una proporción de ácidos acético, propiónico y butírico de 51:14:35, en nuestro sistema la inulina dio una media de AGCC de $29.3 \mathrm{mmol} / \mathrm{L}$, cantidad importante considerando que se utilizó una concentración de sustrato seis veces menor, con una proporción de ácidos acético, propiónico y butírico de 45:34:21.

Los AGCC formados durante la fermentación de fracciones pécticas por Gulfi (2007), fueron para la pectina con bajo contenido de ácido urónico a las 24 h de 1.2 mmol/100 $\mathrm{mg}$, para la pectina de bajo metoxilo de $1.0 \mathrm{mmol} / 100 \mathrm{mg}$ y para el control lactulosa de $0.9 \mathrm{mmol} / 100 \mathrm{mg}$. Estos contenidos fueron significativamente $(\mathrm{p}<0.05)$ inferiores respecto a los obtenidos durante la fermentación de los hidrolizados a ambas temperaturas, ya que las concentraciones oscilaron entre $8.3-29.3 \mathrm{mmol} / \mathrm{L}$ de AGCC, utilizando $15 \mathrm{mg}$ de carbohidratos totales. De acuerdo con las condiciones de experimentación utilizadas en este proyecto la fermentación de los hidratos de carbono presentes en los hidrolizados del tallo de amaranto producen más AGCC que las fracciones pécticas analizadas por el sistema de Gulfi. 
Ferguson y Jones (2000) evaluaron la producción de ácidos grasos de cadena corta mediante la fermentación in vitro de sacáridos, ésteres de sacáridos, fructooligosacáridos, almidones, almidones modificados y polisacáridos no almidonosos. Rafinosa fue utilizada como control, a las $24 \mathrm{~h}$ de la fermentación formo $64.5 \mathrm{mmol} / \mathrm{L}$ de AGCC acético, propionónico y butírico a partir de $15 \mathrm{mg}$ de este carbohidrato. Al comparar los AGCC producidos por los hidrolizados tenemos que respecto a los tratamientos con las medias más bajas como el obtenido a $90{ }^{\circ} \mathrm{C}-90 \mathrm{~min}$ muestra ser significativamente inferior a todas las muestras analizadas por Ferguson y Jones, respecto al hidrolizado que dio la media de producción de AGCC $\left(100{ }^{\circ} \mathrm{C}-60\right.$ min) más alta $(28 \pm 1.4 \mathrm{mmol} / \mathrm{L})$, es significativamente superior a la media de producción de muestras como metil celulosa, celulosa acetato y celulosa butirato. Esta misma media de AGCC no es significativamente diferente a las medias obtenidas por undeca acetato de rafinosa, celulosa, celulosa propionato y goma karaya. Por último respecto a las muestras restantes la media de AGCC de este mismo hidrolizado mostro ser significativamente menor, dentro de la muestras restantes se encuentran los di, tri, tetra y pentasacáridos como sucrosa, el control rafinosa, estaquiosa y verbascosa, los polisacáridos almidón de maíz, almidón tratado con ácido, goma guar y arábiga. Al comparar las medias de producción de los controles inulina y pectina, en nuestro sistema formaron $29.3 \pm 0.3$ y $35.2 \pm 0.4 \mathrm{mmol} / \mathrm{L}$ respectivamente y son menores significativamente a la obtenida por los fructooligosacáridos $(66.6 \mathrm{mmol} / \mathrm{L})$ y pectina (40.9 mmol/L) analizados por Ferguson y Jones. Las diferencias de producción de AGCC observadas pudieron deberse a que ellos utilizaron un inoculo más concentrado ya que lo prepararon con una proporción de heces y buffer de $1: 5 \mathrm{~m} / \mathrm{v}$ y en nuestro caso fue de 1:10 m/v, y adicionaron $1 \mathrm{~mL}$ de inoculo a $7 \mathrm{~mL}$ de medio, y nosotros adicionamos $0.5 \mathrm{~mL}$ a un volumen de medio de $4.5 \mathrm{~mL}$, mostrando con lo anterior la importancia de la cantidad de inoculo y la naturaleza del sustrato utilizado en la fermentación.

Campos-Vega et al., (2009) al evaluar la fermentación in vitro de $100 \mathrm{mg}$ de polisacáridos de diferentes variedades de frijol a través de la producción de AGCC encontraron que a las a las $24 \mathrm{~h}$ se obtuvo la mayor cantidad de cada ácido grasos, en general fue más abundante el acético, seguido del propiónico y el butírico. Las producciones de AGCC fueron 78, 75, 70 y $67 \mathrm{mmol} / \mathrm{L}$ para las variedades Negro 8025, Bayo Madero, Pinto Durango y Azufrado Higuera respectivamente. El control Rafinosa 
dio una producción de $40 \mathrm{mmol} / \mathrm{L}$. Al analizar los AGCC obtenidos de la fermentación de los hidrolizados de $90{ }^{\circ} \mathrm{C}$ que fueron de 8.3-16.3 mmol/L y a $100{ }^{\circ} \mathrm{C}$ de $11.3-28$ $\mathrm{mmol} / \mathrm{L}$ utilizando $15 \mathrm{mg}$ de sustrato, cantidad seis veces menor a la utilizada por Campos-Vega, probablemente de haber utilizado una mayor cantidad de fuente de carbono se hubiera obtenido una mayor concentración de AGCC, que permitiera compararlos.

Barry et al., (1995) realizaron una estimación de la fermentabilidad in vitro de $100 \mathrm{mg}$ de cuatro fuentes de fibra dietética, por medio de la producción de AGCC, los valores que obtuvieron a las $24 \mathrm{~h}$ fueron $4.0,8.3,42.3$ y $62.4 \mathrm{mmol} / \mathrm{L}$ para la celulosa, salvado de maíz, remolacha azucarera y fibra de soya respectivamente. Los hidrolizados del tallo de amaranto presentaron medias a este mismo tiempo de fermentación de 16.3 y 28 $\mathrm{mmol} / \mathrm{L}$ que son las concentraciones más altas de las temperaturas de 90 y $100{ }^{\circ} \mathrm{C}$, y son significativamente superiores a las medias de las fibras de celulosa y el salvado de maíz, a pesar de que estas se utilizaron en mayor cantidad.

De acuerdo con Mortensen et al., (1988) la ferrmentabilidad de la fibra compleja por flora fecal depende de las asociaciones entre los azúcares de la fibra. La xilosa tendría a tener un mayor impacto que la glucosa en la producción de ácido butírico, mientras que la producción de ácido propiónico puede ser promovida por la fermentación de la glucosa y, en menor medida, por el de xilosa y arabinosa.

Debido a que el hidrolizado obtenido a $100{ }^{\circ} \mathrm{C}$ por 60 minutos dio lugar a la mayor producción de ácidos grasos, fueron elegidas estas condiciones para obtener un hidrolizado y separar sus oligosacáridos por cromatografía de filtración en gel. 


\subsection{Obtención de oligosacáridos}

Mediante cromatografía de filtración en gel Sephadex G-25 se separaron los oligosacáridos presentes en el hidrolizado obtenido a $100{ }^{\circ} \mathrm{C}$ por $60 \mathrm{~min}$, a continuación se presenta el perfil de elución de los marcadores y de la muestra.

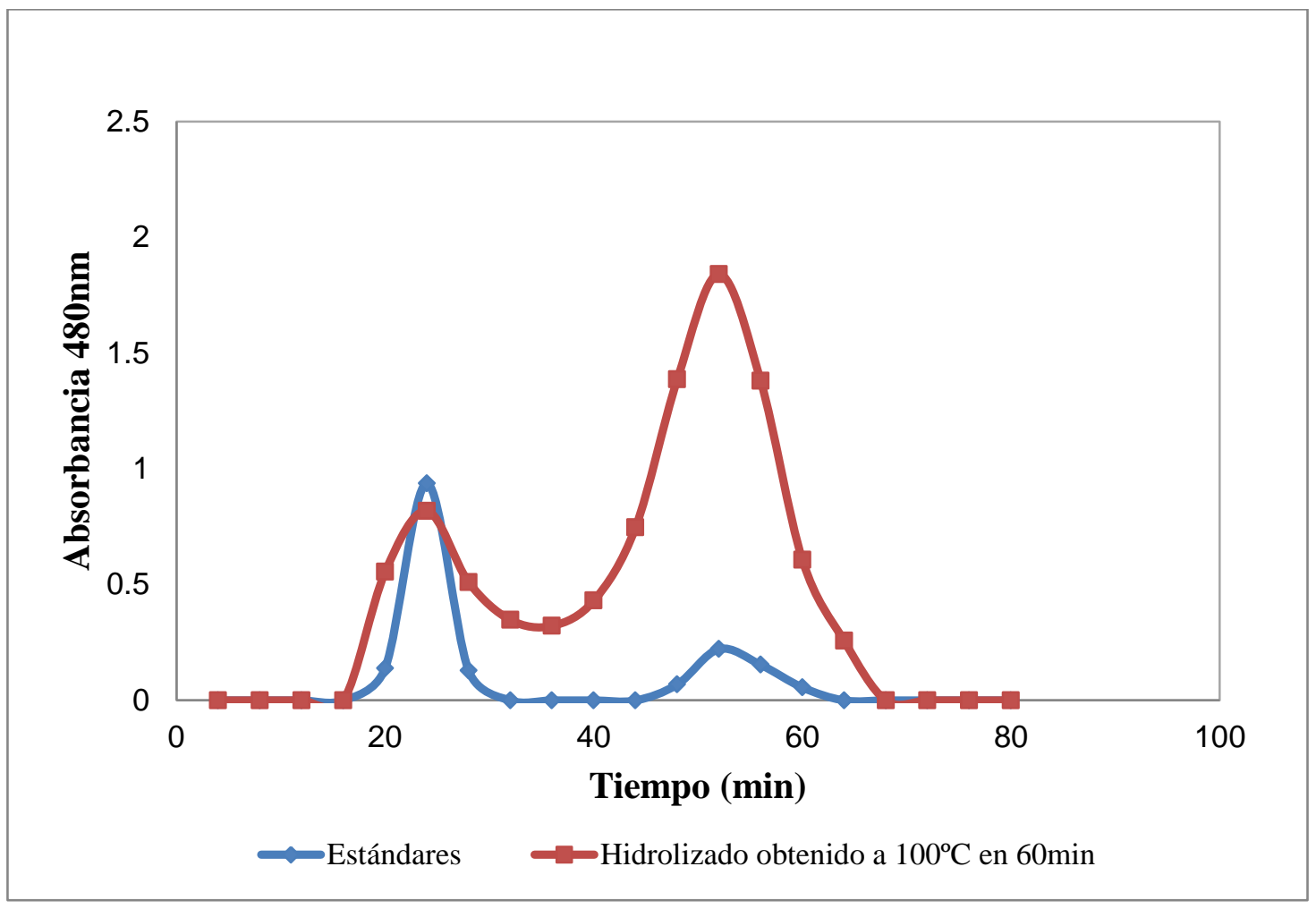

Figura 17. Perfil de elución de los estándares: dextrano y glucosa, y del hidrolizado en Sephadex G-25.

En el cromatograma se observa que los tiempos de elución de los marcadores dextrano y glucosa son 24 y 52 min respectivamente, las fracciones que se colectaron fueron a partir del minuto 44 hasta el 64 y son las que eluyeron al mismo tiempo que la glucosa. El área de los picos fue mayor para el hidrolizado, y su intensidad fue mayor en el tiempo de elución de la glucosa, lo que nos indica que la fibra soluble que contiene este hidrolizado es de un grado de polimerización bajo, incluso conformada por monómeros pues es muy semejante al pico de la glucosa. 
6.4 Evaluación de actividad prebiótica de los oligosacáridos. Fermentación in vitro.

\subsubsection{Cinética de crecimiento}

En la Figura 18 se observan la cinética de crecimiento de las bacterias colónicas en anaerobiosis a partir de la utilización como sustrato de los oligosacáridos, del hidrolizado sin purificar, y de los controles inulina y pectina.

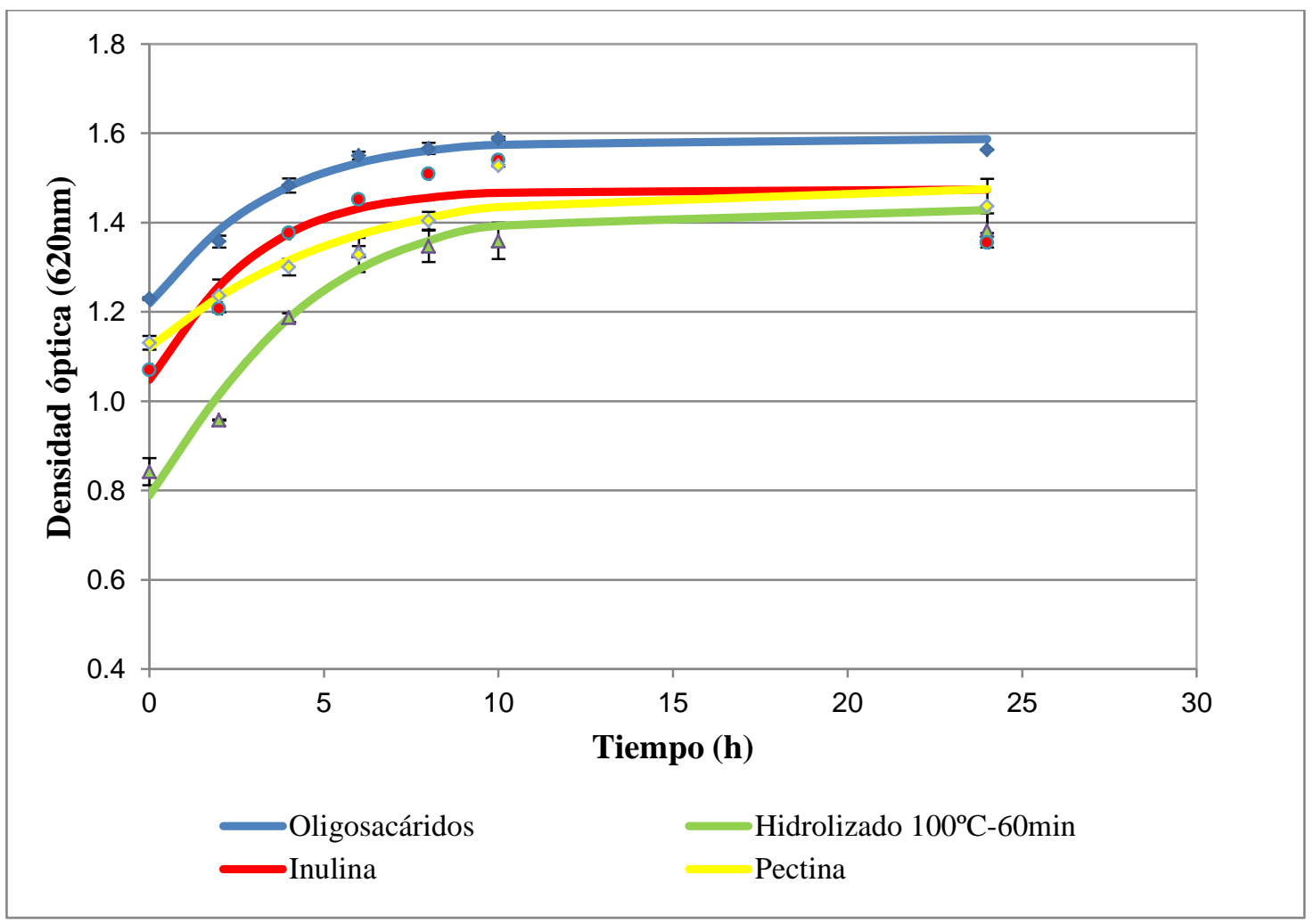

Figura 18. Cinéticas de crecimiento de la fermentación in vitro por bacterias colónicas de los oligosacáridos, del hidrolizado obtenido a $100{ }^{\circ} \mathrm{C}$ por $60 \mathrm{~min}$ y de los controles inulina y pectina.

La cinética de crecimiento de los oligosacáridos obtenidos a partir de la cromatografía en columna es muy similar a la de los controles inulina y pectina, las fases de adaptación (muy corta) y exponenciales son inferiores a seis horas. El hidrolizado presentó una fase exponencial más larga que fue de ocho horas y la cantidad de biomasa formada al final de la fermentación fue similar a la de los controles. 


\subsubsection{Parámetros cinéticos}

Las cinéticas de crecimiento permitieron obtener los parámetros velocidad específica de crecimiento y tiempo de duplicación de los oligosacáridos (Tabla 10).

Tabla 10. Velocidad específica de crecimiento y tiempo de duplicación de los oligosacáridos, del hidrolizado y de los controles.

\begin{tabular}{c|c|c}
\hline MUESTRA & $\begin{array}{c}\text { VELOCIDAD ESPECÍFICA } \\
\text { DE CRECIMIENTO } \\
\left(\boldsymbol{\mu}, \mathbf{h}^{-\mathbf{1}}\right)\end{array}$ & $\begin{array}{c}\text { TIEMPO DE } \\
\text { DUPLICACIÓN } \\
(\mathbf{t d}, \mathbf{h})\end{array}$ \\
\hline Oligosacáridos & $0.36^{\mathrm{w}} \pm 0.04$ & $1.9 \pm 0.1$ \\
HHT $_{\mathbf{6 0}}$ & $0.35^{\mathrm{w}} \pm 0.02$ & $2.0 \pm 0.01$ \\
Inulina & $0.43^{\mathrm{w}} \pm 0.04$ & $1.6 \pm 0.1$ \\
Pectina & $0.24^{\mathrm{w}} \pm 0.02$ & $2.9 \pm 0.2$ \\
\hline
\end{tabular}

Los resultados son el promedio de dos experimentos independientes \pm desviación estándar. $\mathrm{HHT}_{60}$ : Hidrolizado de harina de tallo obtenido a $100{ }^{\circ} \mathrm{C}$ por $60 \mathrm{~min}$.

${ }^{\mathrm{w}}$ Las medias de velocidad específica de crecimiento de distintas muestras no mostraron diferencia significativa $(\mathrm{p}<0.05)$.

Las velocidades específicas de las bacterias colónicas en la fermentación de los oligosacáridos y del hidrolizado sin purificar no mostraron diferencia significativa entre sí y con los controles. Lo que indica que las bacterias crecen a la misma velocidad en estas dos muestras independientemente de que una solamente contenga fuente de carbono y que otra sea un tejido hidrolizado, y con alta fuerza osmótica debido a las sales presentes de la neutralización.

Moura et al., (2007) realizaron la fermentación in vitro de xilooligosacáridos obtenidos a partir de autohidrólisis de mazorcas de maíz. De los hidrolizados separaron por cromatografía de filtración en gel dos fracciones con GP de 3-4 y de 5-6. Los hidrolizados con GP 3-4 fueron fermentados por B. adolescentes así como los hidrolizados comerciales de xilobiosa, mientas que L. brevis prefirió los XOS con GP de 2. Las velocidades específicas utilizando las fracciones oscilaron entre 0.05, 0.06 para L. fermentum hasta $0.26,0.27$ para B. adolescentis, estas velocidades especificas fueron similares al control xilobiosa ya que para estas mismas cepas fueron de $0.05 \mathrm{y}$ $0.30 \mathrm{~h}^{-1}$. Comparando las velocidades de las bacterias colónicas que por cuestiones de tiempo no fueron caracterizadas, mostraron velocidades en los oligosacáridos $\left(0.36 \mathrm{~h}^{-1}\right)$ y del hidrolizado $\left(0.35 \mathrm{~h}^{-1}\right)$ estas fueron significativamente mayores a las observadas por L. fermentun, mientras que para B. adolescentis no mostraron diferencias significativa $(\mathrm{p}<0.05)$. 


\subsubsection{Consumo de hidratos de carbono y rendimiento biomasa-sustrato}

La fermentación de los oligosacáridos dio lugar al consumo de hidratos de carbono que se muestra en la Tabla 11, en ella también se presenta el rendimiento biomasa-sustrato, comparando con el hidrolizado sin purificar y los controles.

Tabla 11. Consumo de hidratos de carbono y rendimiento biomasa-sustrato de la fermentación de los oligosacáridos obtenidos del hidrolizado $100^{\circ} \mathrm{C}-60 \mathrm{~min}$

\begin{tabular}{ccc}
\hline MUESTRA & $\begin{array}{c}\text { CONSUMO DE HIDRATOS } \\
\text { DE CARBONO }(\%)\end{array}$ & $\begin{array}{c}\text { RENDIMIENTO } \\
\text { BIOMASA-SUSTRATO } \\
(\mathbf{Y} \text { / } / \mathbf{s})\end{array}$ \\
\hline Oligosacáridos & $92.2^{\mathrm{X}} \pm 0.3$ & $0.34^{\mathrm{A}} \pm 0.1$ \\
HHT60 & $76.3^{\mathrm{W}} \pm 1.0$ & $0.68^{\mathrm{B}} \pm 0.09$ \\
Inulina & $96.4^{\mathrm{Y}} \pm 1.0$ & $0.28^{\mathrm{A}} \pm 0.01$ \\
Pectina & $92.8^{\mathrm{X}, \mathrm{Y}} \pm 0.2$ & $0.24^{\mathrm{A}} \pm 0.07$ \\
\hline
\end{tabular}

Los resultados con el promedio de dos experimentos independientes \pm desviación estándar. $\mathrm{HHT}_{60}$ : Hidrolizado de harina de tallo obtenido a $100{ }^{\circ} \mathrm{C}$ por $60 \mathrm{~min}$.

W, X, Y Medias de hidratos de carbono en la misma columna con letras distintas son diferentes $(\mathrm{p}<0.05)$.

A, B Medias de rendimiento biomasa-sustrato en la misma columna con letras distintas son diferentes $(\mathrm{p}<0.05)$.

El consumo de oligosacáridos no presentó diferencia significativa respecto al control pectina, pero si a la inulina ya que su consumo por las bacterias colónicas fue mayor. Comparando los oligosacáridos con el hidrolizado se observó diferencia significativa ya que el porcentaje de consumo de este último fue inferior al $80 \%$.

El rendimiento biomasa sustrato fue mayor para el hidrolizado, y fue superior significativamente respecto al rendimiento de los oligosacáridos y de los controles, esto puede deberse a que el hidrolizado al ser un tejido hidrolizado tiene además de fuente de carbono, fracciones proteícas, minerales o compuestos extraíbles por la hidrólisis y esto lo constituye como un medio de cultivo más complejo, que al tener más nutrimentos respecto a los oligosacáridos favorece el crecimiento de las bacterias colónicas lo que es deseable porque produce una mayor cantidad de biomasa, dentro de la que es muy probable que se tengan especies probióticas, porque presentaron descensos de $\mathrm{pH}$ y producción de ácidos orgánicos que se muestran a continuación en los siguientes resultados. 


\subsubsection{Perfil de acidificación}

El cambio de $\mathrm{pH}$ durante la fermentación in vitro de los oligosacáridos por las bacterias colónicas se muestra en la siguiente Figura 19, junto con el hidrolizado sin purificar y los controles inulina y pectina.

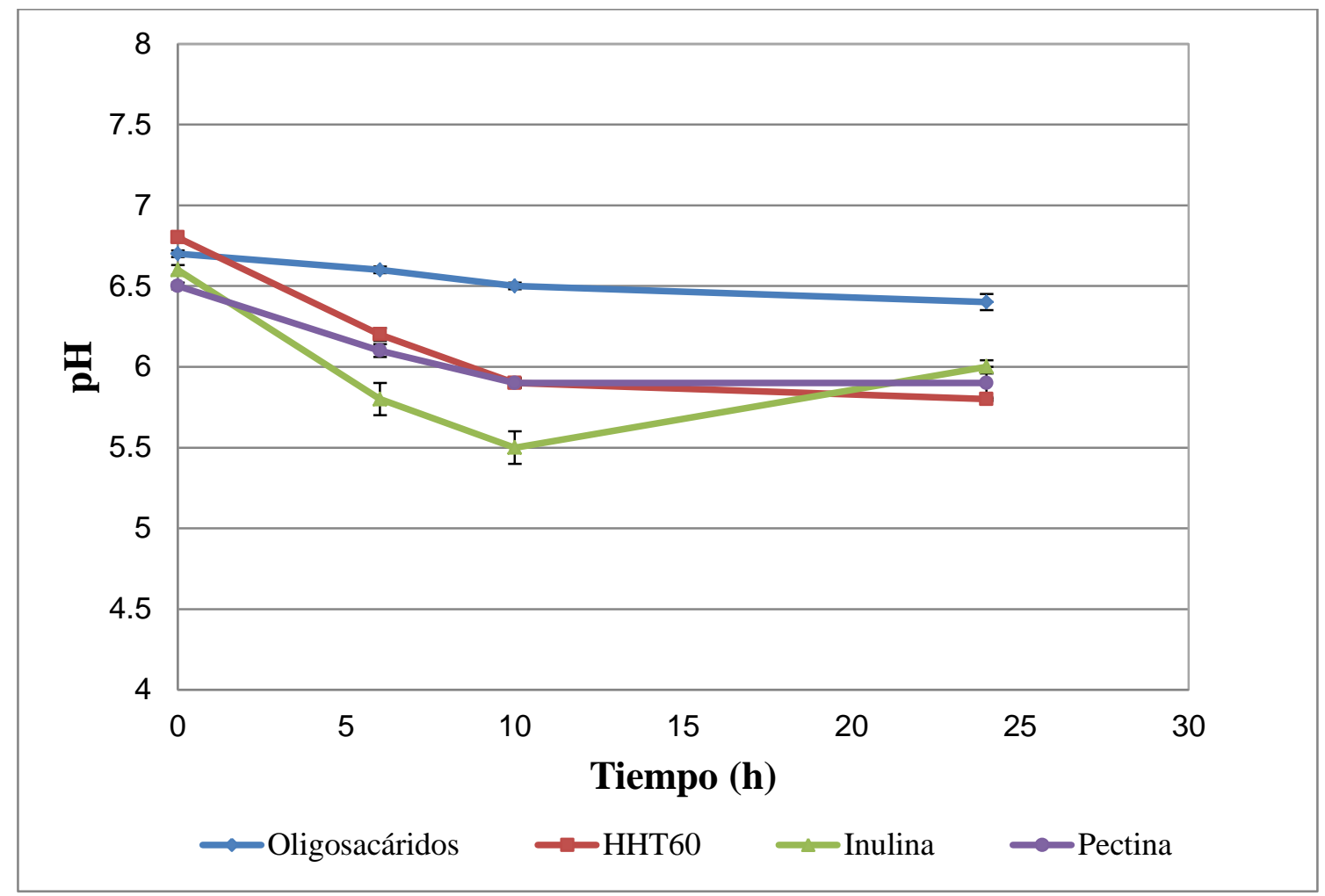

Figura 19.Cambio de pH durante la fermentación de los oligosacáridos, del hidrolizado de $100{ }^{\circ} \mathrm{C}-60 \mathrm{~min}$ y de los controles inulina y pectina.

Los valores son medias de dos repeticiones: errores estándar de las medias son mostrados por las barras verticales.

El descenso de $\mathrm{pH}$ durante la fermentación del hidrolizado sin purificar fue muy semejante al control pectina. El pH más bajo se observó en la inulina a las 10 h. Los cambios de $\mathrm{pH}$ presentados por la fermentación de los oligosacáridos fueron pocos, su descenso fue de 0.3 unidades de $\mathrm{pH}$. A continuación se presenta la producción de ácidos grasos de cadena corta. 


\subsection{5 Ácidos grasos de cadena corta}

La formación de ácidos orgánicos durante la fermentación de los oligosacáridos se presenta en la Figura 20, también aparecen los producidos por el hidrolizado $100{ }^{\circ} \mathrm{C}-$ 60 min sin purificar, así como los controles inulina y pectina.

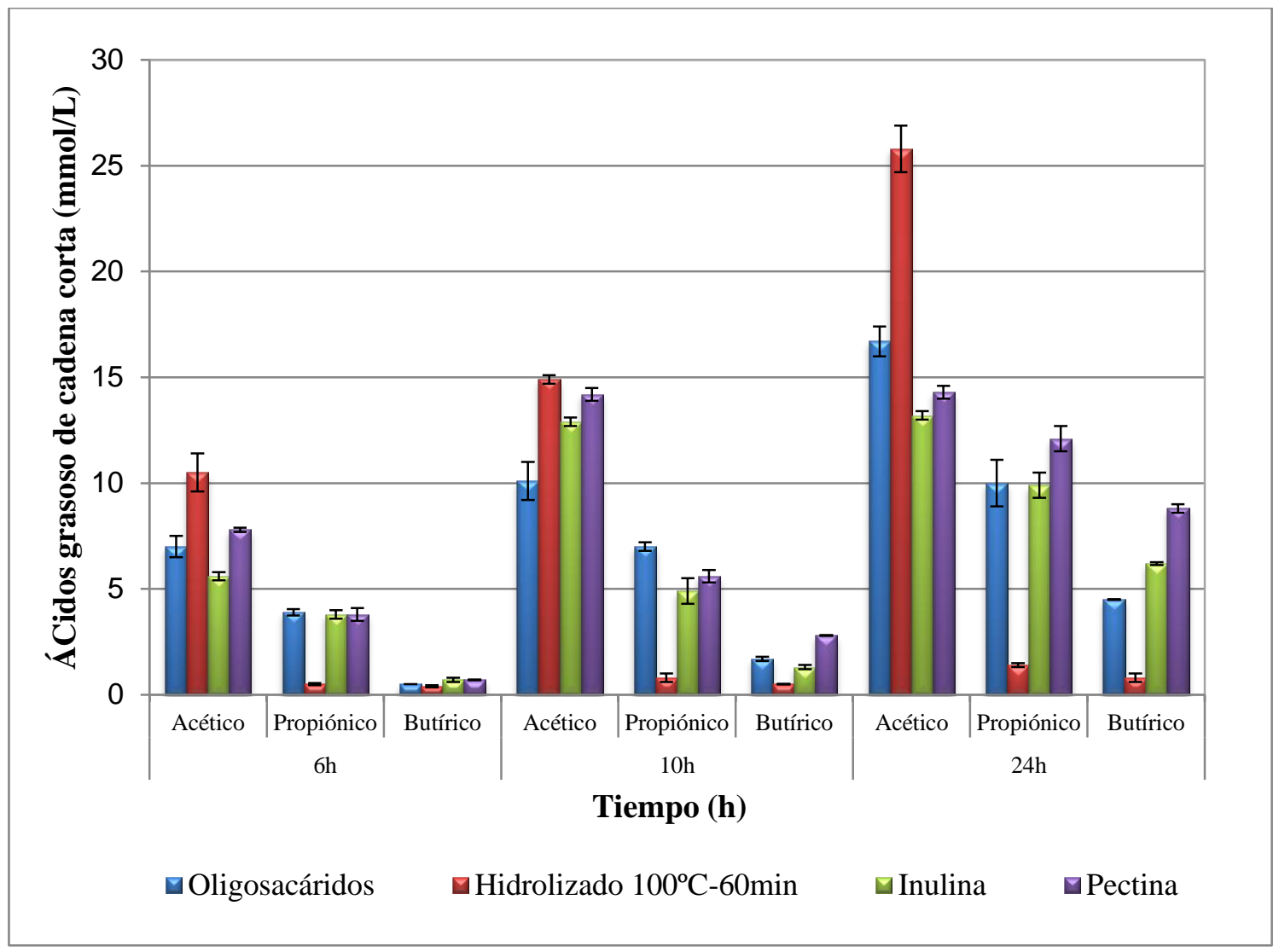

Figura 20. Concentración de ácidos grasos acético, propiónico y butírico en $\mathrm{mmol} / \mathrm{L}$ formados durante la fermentación de los oligosacáridos obtenidos a partir del hidrolizado100 ${ }^{\circ} \mathrm{C}-60 \mathrm{~min}$.

Los valores son medias de dos repeticiones: errores estándar de las medias son mostrados por las barras verticales.

En la figura 20 observamos que el contenido de ácido acético entre los oligosacáridos $(7 \mathrm{mmol} / \mathrm{L})$ y el control pectina $(7.8 \mathrm{mmol} / \mathrm{L})$ no muestra diferencia significativa $(\mathrm{p}<0.05)$ a las $6 \mathrm{~h}$, a las $10 \mathrm{~h}$ todas las medias de producción de este ácido son significativamente diferentes $(\mathrm{p}<0.05)$, siendo la de los oligosacáridos la más baja. El hidrolizado a las $24 \mathrm{~h}$ mostró una media significativamente $(\mathrm{p}<0.05)$ mayor de este ácido $(25.8 \mathrm{mmol} / \mathrm{L})$.

El ácido propiónico formado en la fermentación de los oligosacáridos (3.9 mmol/L) a las 6 h no mostró diferencia significativa $(\mathrm{p}<0.05)$ respecto a la concentración de los 
controles $(3.8 \mathrm{mmol} / \mathrm{L}$ para ambos inulina y pectina). A las $10 \mathrm{~h}$ la media de ácido propiónico producida por los oligosacáridos $(7 \mathrm{mmol} / \mathrm{L})$ fue significativamente $(\mathrm{p}<0.05)$ mayor en relación a la hidrolizado sin purificar y a los controles $(0.8,4.9$ y 5.6 $\mathrm{mmol} / \mathrm{L}$ respectivamente), y a las $24 \mathrm{~h}$ la media de este mismo ácido formado por los oligosacáridos $(10 \mathrm{mmol} / \mathrm{L})$ solamente fue significativamente diferente a la del hidrolizado $(1.4 \mathrm{mmol} / \mathrm{L})$.

La concentración de ácido butírico para las cuatro muestras a las 6 h no mostró diferencia significativa $(\mathrm{p}<0.05)$, a las $10 \mathrm{~h}$ el control pectina $(8.8 \mathrm{mmol} / \mathrm{L})$ dio una media significativamente mayor a las demás muestras $(4.5,0.8$ y $6.2 \mathrm{mmol} / \mathrm{L}$ oligosacáridos, $\mathrm{HHT}_{60}$ e inulina), y a las $24 \mathrm{~h}$ la media de producción de los oligosacáridos $(4.5 \mathrm{mmol} / \mathrm{L})$ fue significativamente $(\mathrm{p}<0.05)$ inferior a la media de los controles $(6.2 \mathrm{mmol} / \mathrm{L}$ inulina y $8.8 \mathrm{mmol} / \mathrm{L}$ pectina $)$.

Kabel et al., (2002), llevaron a cabo la fermentación in vitro de xilooligosacáridos (XOS) con distintos grupos, estos fueron xilooligosacáridos no sustituidos (XOSn), arabinoxilano-XOS (AXOS), XOS acetilados (XOSAc) y XOS que contenían grupos de ácido 4-O-metilglucurónico (XOSAcme). En la fermentación con el inoculo1, se observó que a las siete horas el ácido graso formado fue únicamente acetato, su producción fue de 2,4 y $6 \mathrm{mmol} / \mathrm{L}$ para los XOSn, XOSAc y los AXOS respectivamente, y para los XOSAcme no se observó aun la aparición de este ácido, medias de producción que son significativamente menores a la observada por los oligosacáridos a las $6 \mathrm{~h}(11.4 \pm 0.2)$. Conforme avanzo el tiempo aumento la producción de ácidos, a las 27 horas obtuvieron concentraciones de ácidos de 20 (únicamente acetato), 24 (acetato 16, propionato 8), 9 (acetato 6, propionato 3), 18 (acetato 14, propionato 4) mmol/L para los XOSn, XOSAc, XOSAcme y AXOS respectivamente. El butirato en general fue el ácido en menor proporción, conforme aumento el tiempo, la concentración de los AGCC aumentó. Estas concentraciones son significativamente menores a las medias de producción de AGCC de los oligosacáridos a las 24h $(31.2 \pm$ $1.0)$. 


\section{CONCLUSIONES}

La hidrólisis del tallo de amaranto, que se realizó con $\mathrm{H}_{2} \mathrm{SO}_{4}$ al $5.0 \%(\mathrm{~m} / \mathrm{v})$, temperaturas de 90 y $100{ }^{\circ} \mathrm{C}$, y tiempos de hidrólisis de 30, 60, 90, 120 y 150 min, permitió obtener fibras solubles que son capaces de ser metabolizadas por bacterias colónicas. La fermentación de la fibra soluble incrementó el número de bacterias colónicas, descenso de $\mathrm{pH}$ y los parámetros cinéticos de manera similar a los controles de inulina y pectina. La producción de ácidos grasos de cadena corta fue comparable a los controles de inulina y pectina que se utilizaron en este experimento.

La fermentación de los oligosacáridos (obtenidos a $100{ }^{\circ} \mathrm{C}$ durante 60 min) por bacterias colónicas, resultó en un mayor consumo de hidratos de carbono (92.2\%) y un incremento en la producción de ácidos grasos de cadena corta (11.4 y $31.2 \mathrm{mmol} / \mathrm{L})$ respecto a los resultados obtenidos del hidrolizado sin purificar (11.3 y $28.0 \mathrm{mmol} / \mathrm{L})$. La producción de ácidos grasos de cadena corta, mostró ser significativamente superior al control de inulina (10.1 y $29.3 \mathrm{mmol} / \mathrm{L})$. Los oligosacárjdos derivados de la hidrólisis ácida del tallo de amaranto revelaron tener capacidad prebiótica en una fermentación sumergida en condiciones de anaerobiosis. 


\section{BIBLIOGRAFÍA}

A.A.C.C. American Association of Cereal Chemist. 2001. Report of the definition of dietary fiber. Cereal FoodsWorld. 46. 112-114.

Adrian J.2000. Análisis nutricional de los Alimentos. Acribia. España. 56-62.

Aguilar R., Ramirez J.A., Garrote G., Vázquez M. 2002. Kinetic study of the acid hydrolysis of sugar cane bagasse. Journal of Food Engineering. 55: 309-318.

Aguilar N. y Canizales, M. 2004. Cinética de la hidrólisis ácida de la cascarilla de cebada. Revista Mexicana de Ingeniería Química. 3. 257-263.

Arce R. B. 2011. Obtención de Compuestos Biofuncionales a partir de Material Lignocelulósico de Amaranthushypochondriacus L. Universidad Autónoma Metropolitana.

Arellano J. y Galicia, J. 2007. Rendimiento y características de planta y panoja de amaranto en respuesta a nitrógeno y cantidad de semilla. Agricultura Técnica en México. 33. 251-258.

Badui S. 2006. Química de los Alimentos. 4ª Edición. Alambra. 91-94, 117-119, 538540.

Barrio M. A. 2006. Probióticos, prebióticos y simbióticos. Definición, funciones y aplicación clínica en pediatría. Revista Pediatría de Atención Primaria. 8: 99-118.

Barry J. L., Hoebler C., Macfarlane G. T., Macfarlane S., Mathers J. C., Reed K. A., Mortensen P. B., Nordgaard I., Rowland I. R., y Rumney C. J. 1995. Estimation of the fermentability of dietary fibre in vitro: a European interlaboratory study. British Journal of Nutrtion. 74: 303-322.

Bennett W. y Cerda, J. 1996.Benefits of dietary fiber. Myth or medicine? Postgrad Med. 99.153-172.

Brito C. 2009. Revaloración de la Funcionalidad Fisiológica de la Leche y los Lácteos. Estudios de optimización. Agro Sur, 37(2), 71-80. 
Campos-Vega R., Reynoso-Camacho R., Pedraza-Aboytes G., Acosta-Gallegos J.A., Guzmán-Maldonado S.H., Paredes-López O., Oomah B.D., y Loarca-Piña G. 2009. Journal of Food Science. 74. 59-65.

Collins T., Gerday C., Feller G., 2005. Xylanases, xylanase families and extremophilic xylanases, FEMS Microbiology Reviews 29, 3-23.

Conde E., Gullon P., Moure A., Dominguez H. y Parajó J. C., 2009. Fraction of industrial solids containing barley husks in aqueous media. Food and Byproducts Processing. 87: 208-214.

Dongowski G. y Lorenz A. 1998. Unsaturated oligogalacturonic acids are generated by in vitro treatment of pectin with human faecal flora. Carbohydrate Research 314: 237244.

Dubois M., Gilles K.A., Hamilton J. K., Rebers P.A y Smith F. 1956.Colorimetric Method for determination of sugars and related substances. Analytical Chemistry.28: $350-356$.

Escudero A. y González S. 2006. La fibra dietética. Nutrición Hospitalaria. 21. 61-72.

Ferguson M. J. y Jones G. Production of short-chain fatty acids following in vitro fermentation of saccharides, saccharide esters, fructo-oligosaccharides, starches, modified starches and non-starch polysaccharides. Journal of the Science of Food and Agriculture. 80: 166-170.

Fllnt H. J. Duncan S.H. Scott K. P. y Louis P. 2007. Interactions and competition within the microbial community of the human colon: links between diet and health. Environmental Microbiology. 9: 1101-1111.

García O. 2002. Enciclopedia de la fibra. Kellog de México.

Gibson G., y Roberfroid M. 2008. Handbook of Prebiotics.CRC Press.1-92.

Gulfi M., Arrigoni E., Amadò R., 2007. In vitro fermentability of a pectin fraction rich in hairy regions. Carbohydrate Polymers. 67: 410-416.

Holzapfel W. H. y Schillinger U. 2002. Introduction to pre- and probiotics.Food Research International. 35: 109-116. 
John M., Schmidt J., Wandrey C. y Sahm H. 1982. Gel chromatography of oligosaccharides up to DP 60. Journal of Chromatography. 247: 281-288.

John M., Trénel G. and Dellweg H. 1969. Quantitative chromatography of homologous glucose oligomers and other saccharides using polyacrylamide gel. Journal of chromatography. 42: 476-484.

Kabel M. A., Kortenoeven L., Schols H. A., y Voragen A. G. J. 2002. In vitro Fermentability of Differently Substituted Xylo-oligosaccharides. Journal of Agricultural and Food Chemistry. 50: 6205-6210.

Karppinen S., Liukkonen K., Aura A. M., Forsell P., y Poutanen K. 2000. In vitro fermentation of polysaccharides of rye, wheat and oats brans and inulin by human faecal bacteria. Journal of Science of Food and Agriculture. 80: 1496-1476.

Lebet V., Arrigoni E. y Amadó R. 1998. Measurement of Fermentation Products and Substrate Disappearance During Incubation of Dietary Fibre Sources with Human Faecal Flora. Academic Press. 473-479.

Lourens-Hatting A. y B. C. Viljoen. 2001. Yogurt as probiotic carrier food. Review.International Dairy Journal. 11: 1-17.

MacFarlane G. T. y. Cummings J. H. 1999. Probiotics and prebiotics: can regulating the activities of intestinal bacterial benefit health? Education and debate. 318: 999-1002.

Madigan M. T. Martinko J. M. Parker J. 2003. Brock Biología de los microorganismos. Décima edición. Pearson. 584-586.

Miller G.L. 1959. Use of Dinitrosalicykic Acid Reagent for Determination of Reducing Sugar. Analytical Chemistry. 31: 426-428.

Morales G., Vázquez, N. Bressani, R. 2009. El amaranto. Características físicas, químicas, toxicológicas y funcionales y aporte nutricio. $1^{\text {a }}$ Edición. Instituto Nacional de Ciencias Médicas y Nutrición Salvador Zubirán. 15-233.

Moura P., Barata R., Carvalheiro F., Gírio F., Loureiro-Dias M. C., Esteves M. P. 2007. In vitro fermentation of xylo-oligosaccharides from corn cobs autohydrolysis by Bifidobacterium and Lactobacillus strains. LWT- Food Science and Technology. 40: 963-972. 
Mussatto S.I., y Roberto I.C. 2004. Alternatives for detoxification of diluited-acid lingocellulosic hydrolyzates for use in fermentative processes: a review. Bioresource Technology. 93: 1-10.

Okazaki M., Fujikawa S. y Matsumoto N. 1990. Effects of xylooligosaccharide on growth of bifidobacteria, J. Jpn. Soc. Nutr.FoodSci. 43, 395.

Olano-Martin E. Gibson G.R. y Rastall R.A. 2002. Comparison of the in vitro bifidogenic properties of pectins and pectic-oligosaccharides. Journal of Applied Microbiology. 93: 505-511.

Paredes L. O., Guevara L. F. y Bello P. L. 2006. Los alimentos mágicos de las culturas indígenas mesoamericanas. Secretaría de Educación Pública. Fondo de Cultura Económica y Consejo de Nacional de Ciencia y Tecnología. 212. 88-104.

Paz-Lago D., y Hernández M. 2000. Purificación y caracterización parcial de la enzima xilanasa a partir del preparado comercial Novoban 240. Cultivos tropicales 21: 27-31.

Pompei A., Cordisco L., Raimondi A., Amaretti A., Pagnoni U. M., Matteuzzi D., Rossi M. 2008. In vitro comparison of the prebiotic effects of two inulin-type fructans. Anaerobe. 14: 280-286.

Raccach M. 2004. Pediococcus. Encyclopedia of Food Microbiology. 1641-1647.

Ramírez-Gama R. M., Luna B., Velásquez O., Vierna L., Mejía A. G., Tsuzuki M. G., Hernández L., Camacho A. y Urzúa M. C. 2011. Manual de Prácticas de Microbiología General. México: UNAM, Facultad de Química.

Robles S. 2001. ¿Qué es la fibra dietética? Centro Nacional de Alimentación y Nutrición. Boletín Instituto Nacional de Salud. 7. 13-14.

Schmidt F. y Enevoldsen B. 1976. Gel filtration chromatography of oligosaccharides, comparative studies of $\alpha-1,4, \alpha-1,6$ and $\alpha-1,4: \alpha-1,6$ linked oligosaccharides composed of glucose. Carlsber Res. Commun. 41. 91-110.

Secretaría de Agricultura, Ganadería, Desarrollo Rural, Pesca y Alimentación, 2010. Anuario Estadístico de la Producción Agrícola. Gobierno Federal. Consultado en www.siap.gob.mx el 20 de marzo de 2012. 
Swennen K., Courtin C. M. y Delcour J.A. 2006. Non-digestible oligosaccharides with prebiotic properties, Critical Reviews in Food Science and Nutrition 46: 459-471.

Ulloa J.A., Andrews H. E., Cruz G. K., Ulloa P. R., Ulloa B. E., Ramírez J.C. 2010. Los fructanos y su papel en la promoción de la salud. Revista Fuente Año 2, No. 5, Diciembre. ISSN 2007 - 0713.

Vegas R., Alonso J.L., Dominguez H., Parajó J.C. 2004. Processing of Rice Husk Autohydrolysis Liquors for Obtaining Food Ingredients. Journal of Food Agricultural and Food Chemistry. 52: 7311-7317.

Yamada H. 1993. Structure and properties of oligosaccharides from wheat bran.Cereal FoodsWorld. 38. 490-492. 


\section{ANEXOS}

\section{ANEXO A}

Curva estándar para la cuantificación de azúcares reductores totales expresada en mg de xilosa por $\mathrm{mL}$.

En la Tabla A1 se muestran las concentraciones utilizadas para la construcción de la curva estándar, que sirvió para la cuantificación de azúcares reductores totales en las muestras analizadas en el presente estudio.

En la gráfica A1 se presenta la curva de azúcares reductores totales (mg xilosa/mL) versus absorbancia a 540nm y su respectiva ecuación obtenida de su linealización.

Tabla A1. Curva estándar de xilosa para cuantificación de azúcares reductores totales.

\begin{tabular}{cc}
\hline Xilosa $[\mathbf{m g} / \mathbf{m L}]$ & $\begin{array}{c}\text { Absorbancia } \\
(\mathbf{5 4 0 n m})\end{array}$ \\
\hline $\mathbf{0}$ & $0 \pm 0$ \\
$\mathbf{0 . 4}$ & $0.191 \pm 0.01$ \\
$\mathbf{0 . 8}$ & $0.380 \pm 0.01$ \\
$\mathbf{1 . 2}$ & $0.528 \pm 0.002$ \\
$\mathbf{1 . 6}$ & $0.675 \pm 0.02$ \\
$\mathbf{2 . 0}$ & $0.846 \pm 0.02$ \\
\hline
\end{tabular}

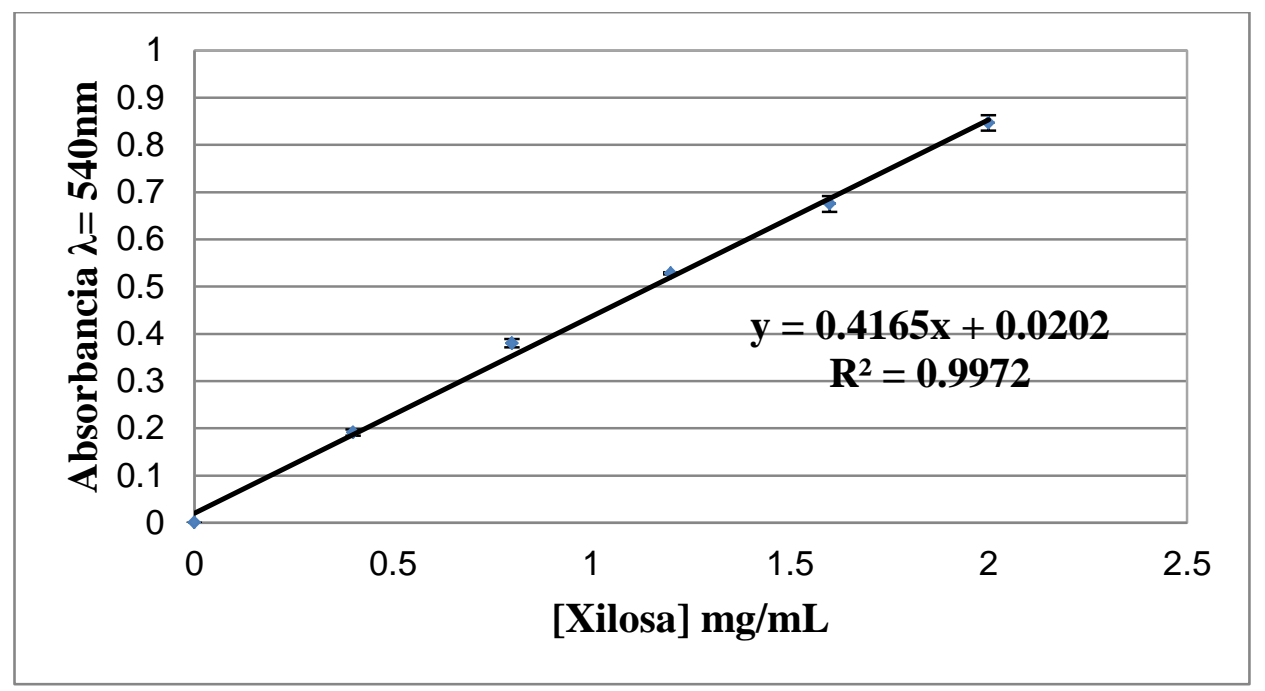

Gráfica A1. Curva estándar de xilosa para cuantificación de azúcares reductores. 


\section{ANEXO B \\ Curva estándar para la cuantificación de azúcares totales expresada en $\mu \mathrm{g}$ de glucosa por $\mathbf{m L}$.}

En la Tabla A2 se muestran las concentraciones utilizadas para la elaboración de la curva estándar, que permitió cuantificar el contenido de azúcares totales en las muestras analizadas en el presente estudio.

En la gráfica A2 se presenta la curva de glucosa $(\mu \mathrm{g} / \mathrm{mL})$ versus absorbancia a $480 \mathrm{~nm}$ y su respectiva ecuación de la línea recta para la determinación de azúcares totales.

Tabla A2. Curva estándar de glucosa para cuantificación de azúcares totales.

\begin{tabular}{cc}
\hline $\begin{array}{c}\text { Glucosa } \\
(\boldsymbol{\mu g} / \mathbf{m L})\end{array}$ & $\begin{array}{c}\text { Absorbancia } \\
(\mathbf{4 8 0 n m})\end{array}$ \\
\hline $\mathbf{0}$ & $0 \pm 0$ \\
$\mathbf{2 0}$ & $0.177 \pm 0.02$ \\
$\mathbf{4 0}$ & $0.345 \pm 0.05$ \\
$\mathbf{6 0}$ & $0.559 \pm 0.04$ \\
$\mathbf{8 0}$ & $0.698 \pm 0.04$ \\
$\mathbf{1 0 0}$ & $0.845 \pm 0.01$ \\
\hline
\end{tabular}

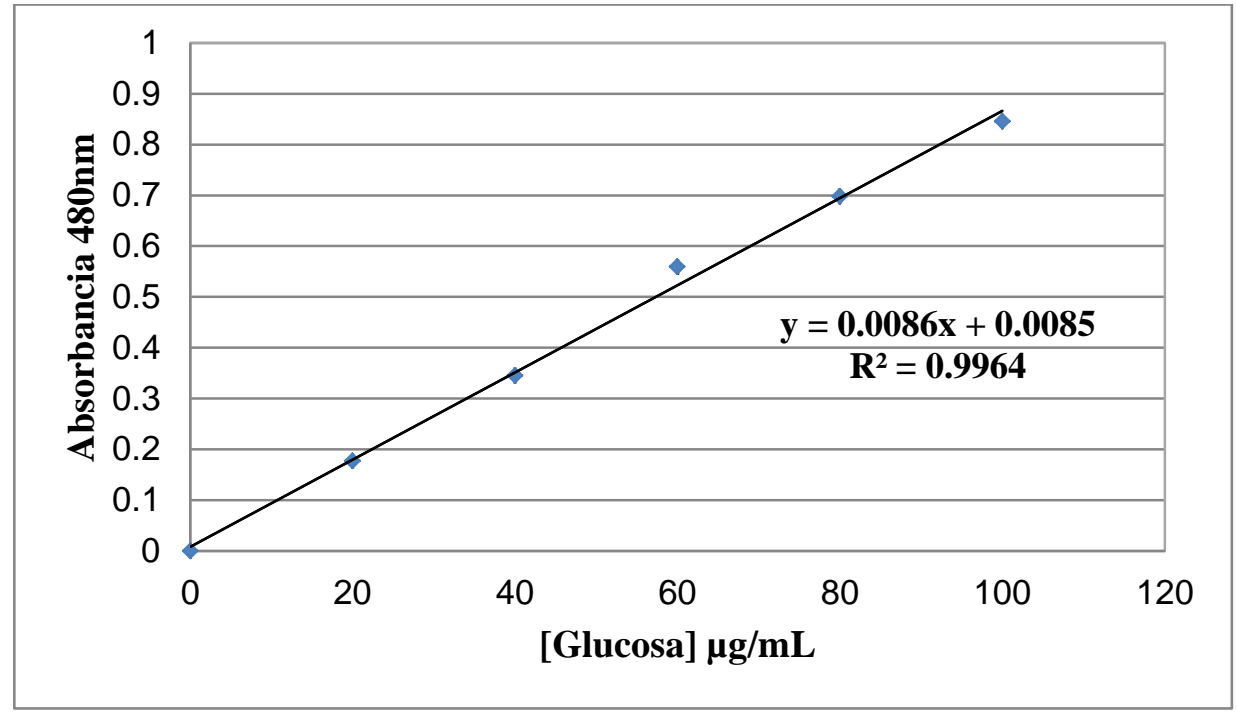

Gráfica A1. Curva estándar de glucosa para cuantificación de azúcares totales. 


\section{ANEXO C}

\section{Curva estándar para la cuantificación de ácido acético.}

En la Tabla A3 aparecen las concentraciones utilizadas para la construcción de la curva estándar, que permitió cuantificar el acetato presente en el medio durante la fermentación.

En la gráfica A3 aparece la curva de ácido acético $\left(\mathrm{mmol}^{*} \mathrm{~L}^{-1}\right)$ versus área $\left(\mathrm{pA}^{*} \mathrm{~s}^{-1}\right)$ y su ecuación de la línea recta para la determinación de este ácido graso.

Tabla A3. Curva estándar de ácido acético.

\begin{tabular}{cc}
\hline $\begin{array}{c}\text { Ácido acético] } \\
\mathbf{m m o l}^{*} \mathbf{L}^{-\mathbf{1}}\end{array}$ & $\begin{array}{c}\text { Área } \\
\left(\mathbf{p A} \mathbf{*}^{\mathbf{- 1}}\right)\end{array}$ \\
\hline $\mathbf{0 . 5 7}$ & $92.05 \pm 2.3$ \\
$\mathbf{2 . 2 7}$ & $181.9 \pm 5.1$ \\
$\mathbf{4 . 5 4}$ & $273.2 \pm 4.0$ \\
$\mathbf{6 . 8 2}$ & $372.9 \pm 7.4$ \\
$\mathbf{9 . 0 9}$ & $488.1 \pm 3.3$ \\
$\mathbf{1 1 . 3 6}$ & $595.8 \pm 9.1$ \\
\hline
\end{tabular}

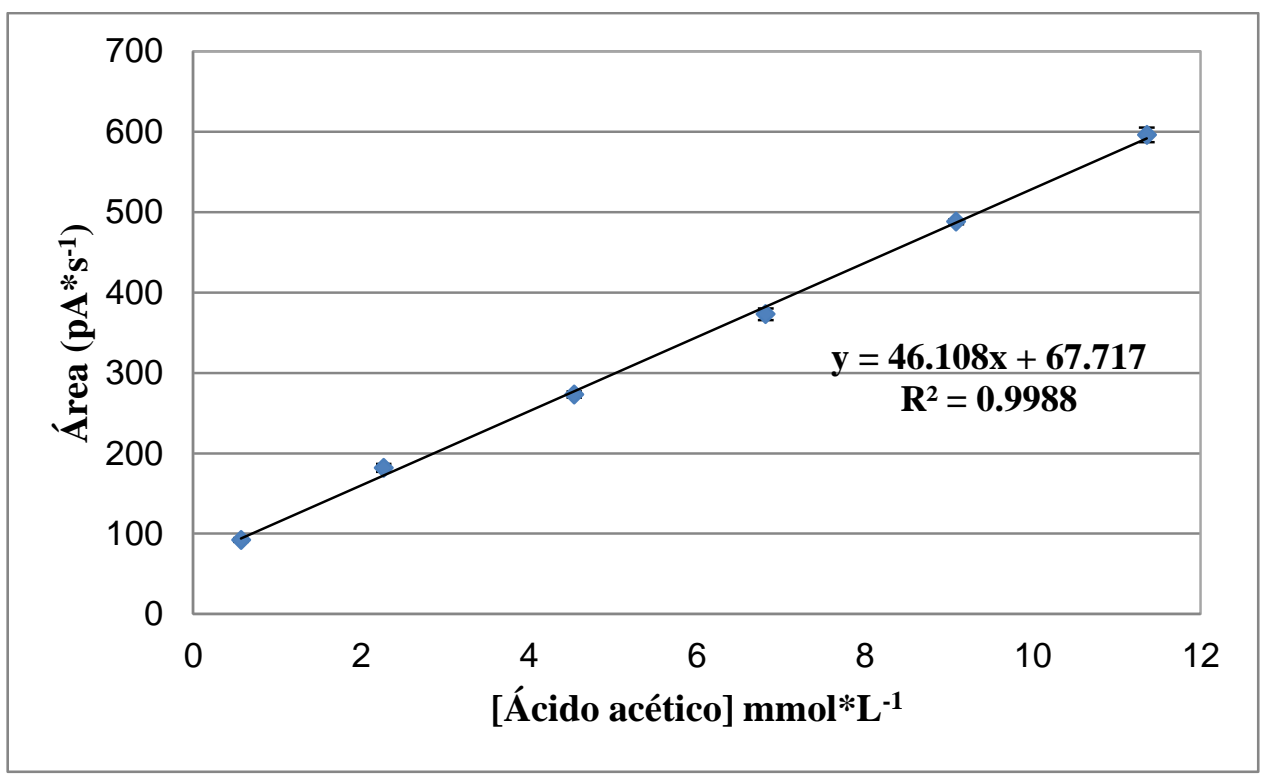

Gráfica A3. Curva estándar de ácido acético. 


\section{ANEXO D}

\section{Curva estándar para la cuantificación ácido propiónico}

En la Tabla A4 se muestran las concentraciones utilizadas para la construcción de la curva estándar, que permitió cuantificar el ácido propiónico presente en el medio durante la fermentación.

En la gráfica A4 aparece la curva de ácido propiónico $\left(\mathrm{mmol}^{*} \mathrm{~L}^{-1}\right)$ versus área $\left(\mathrm{pA}^{*} \mathrm{~s}^{-1}\right)$ y su ecuación de la línea recta para la determinación de este ácido graso.

Tabla A4. Curva estándar de ácido propiónico.

\begin{tabular}{cc}
$\begin{array}{c}\text { [Ácido propiónico] } \\
\mathbf{m m o l}^{*} \mathbf{L}^{-\mathbf{1}}\end{array}$ & Área $\left(\mathbf{p A} \mathbf{s}^{-\mathbf{1}}\right)$ \\
\hline $\mathbf{0 . 0 4 9}$ & $0.46 \pm 0.005$ \\
$\mathbf{0 . 2 4 5}$ & $1.24 \pm 0.09$ \\
$\mathbf{0 . 4 9 0}$ & $2.81 \pm 0.3$ \\
$\mathbf{2 . 4 5 1}$ & $15,32 \pm 1.7$ \\
$\mathbf{4 . 9 0 2}$ & $28.65 \pm 1.9$ \\
\hline
\end{tabular}

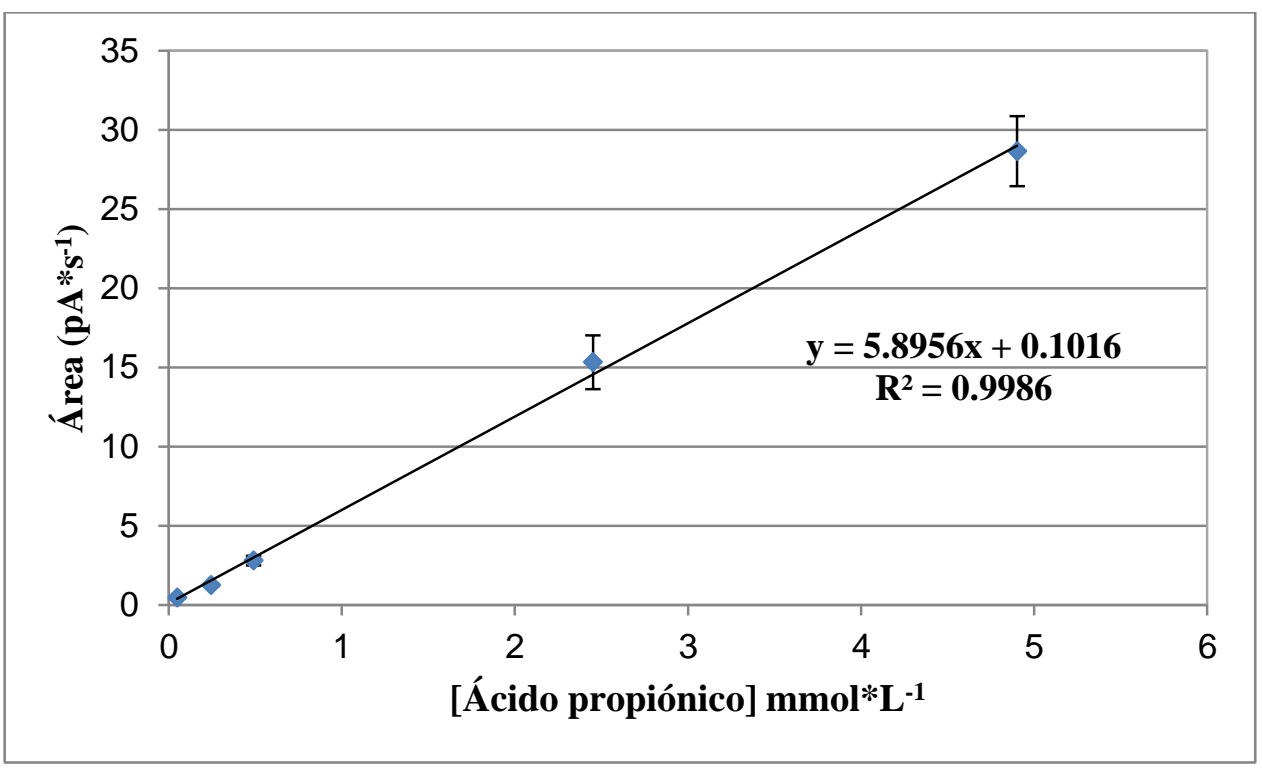

Gráfica A4. Curva estándar de ácido propiónico. 


\section{ANEXO E}

\section{Curva estándar para la cuantificación ácido butírico.}

En la Tabla A5 se muestran las concentraciones utilizadas para la construcción de la curva estándar, que permitió cuantificar el ácido butírico presente en el medio durante la fermentación.

En la gráfica A5 aparece la curva de ácido butíricco $\left(\mathrm{mmol}^{*} \mathrm{~L}^{-1}\right)$ versus área $\left(\mathrm{pA}^{*} \mathrm{~s}^{-1}\right) \mathrm{y}$ su ecuación de la línea recta para la determinación de este ácido graso.

Tabla A5. Curva estándar de ácido butírico. [Ácido butírico] $\mathbf{m m o l} * L^{-1} \quad$ Área $\left(\mathbf{p A}^{*} \mathbf{s}^{-1}\right)$

\begin{tabular}{rl}
\hline $\mathbf{0 . 0 4 3}$ & $0.60 \pm 0.01$ \\
$\mathbf{0 . 2 1 5}$ & $1.91 \pm 0.06$ \\
$\mathbf{0 . 4 3 1}$ & $3.62 \pm 0.02$ \\
$\mathbf{2 . 1 5 5}$ & $17.96 \pm 2.2$ \\
$\mathbf{4 . 3 1 0}$ & $33.20 \pm 1.7$ \\
\hline
\end{tabular}

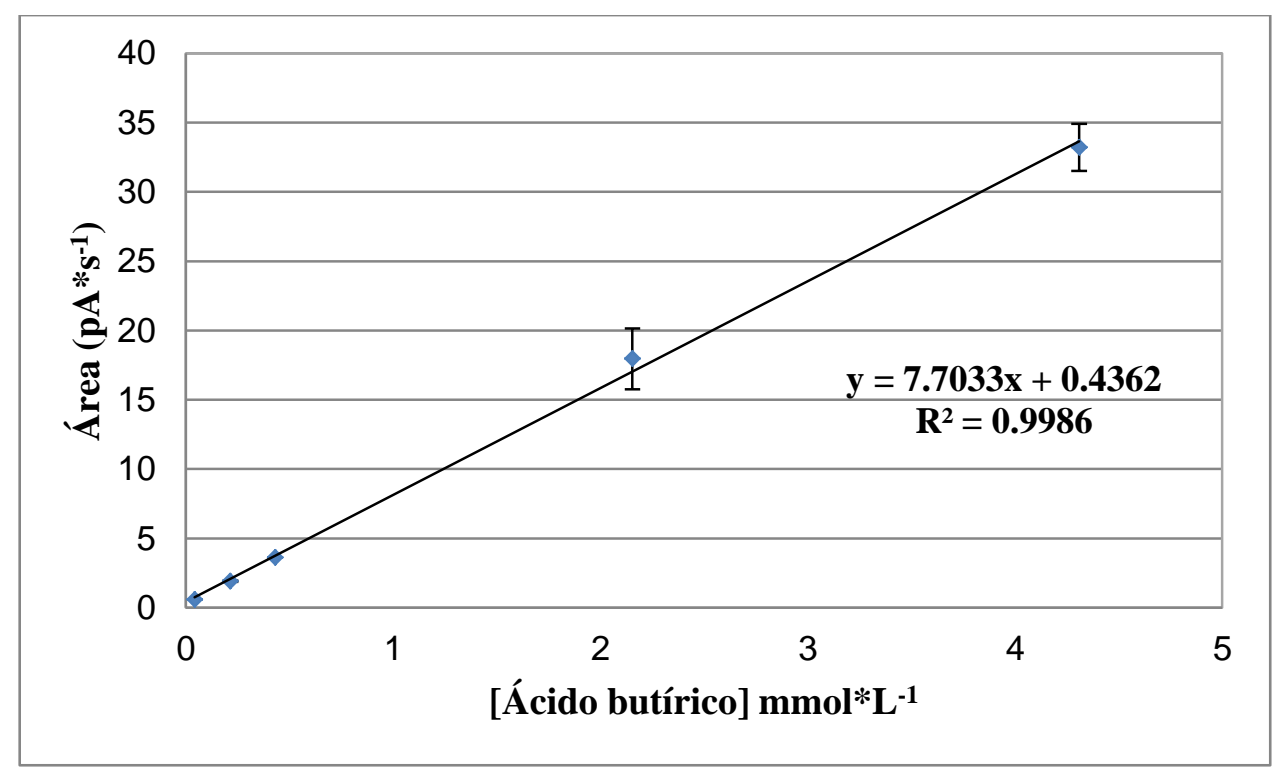

Gráfica A5. Curva estándar de ácido butírico. 


\section{ANEXO F}

En la Tabla A6 aparecen el pH, contenido de AGCC y proporción molar en la fermentación in vitro de los hidrolizados obtenidos a $90^{\circ} \mathrm{C}$.

\begin{tabular}{|c|c|c|c|c|c|c|}
\hline \multirow[b]{2}{*}{ Muestra } & \multirow{2}{*}{$\begin{array}{c}\text { Tiempo } \\
\text { (h) }\end{array}$} & \multirow[b]{2}{*}{ pH } & \multirow{2}{*}{$\begin{array}{c}\text { Ésteres de } \\
\text { ácidos } \\
\text { grasos } \\
\text { totales } \\
\left(\mathbf{m m o l}^{-1} \mathbf{L}^{-1}\right) \\
\end{array}$} & \multicolumn{3}{|c|}{ Proporción molar (\%) } \\
\hline & & & & Acético & Propiónico & Butirico \\
\hline \multirow[t]{3}{*}{$\mathrm{HHT}_{30}$} & 0 & $6.75 \pm 0.03$ & -- & -- & -- & -- \\
\hline & 6 & $6.66 \pm 0.03$ & $15.6^{\mathrm{c}} \pm 0.9$ & $96.1 \pm 1.0$ & $1.9 \pm 0.0$ & $1.9 \pm 0.02$ \\
\hline & 24 & $6.18 \pm 0.01$ & $12.1^{\mathrm{b}, \mathrm{c}} \pm 1.3$ & $90.9 \pm 1.5$ & $4.1 \pm 0.03$ & $4.9 \pm 0.05$ \\
\hline \multirow[t]{3}{*}{$\mathrm{HHT}_{60}$} & 0 & $6.66 \pm 0.06$ & -- & -- & -- & -- \\
\hline & 6 & $6.53 \pm 0.01$ & $13.9^{\mathrm{c}} \pm 1.1$ & $93.5 \pm 0.9$ & $3.6 \pm 0.1$ & $2.9 \pm 0.05$ \\
\hline & 24 & $6.21 \pm 0.02$ & $9.8^{\mathrm{a}, \mathrm{b}} \pm 0.5$ & $9 \pm 1.2$ & $0.5 \pm 0.0$ & $0.3 \pm 0.07$ \\
\hline \multirow[t]{3}{*}{$\mathrm{HHT}_{90}$} & 0 & $6.78 \pm 0.02$ & -- & -- & -- & -- \\
\hline & 6 & $6.3 \pm 0.02$ & $14.6^{\mathrm{c}} \pm 0.2$ & $89.0 \pm 0.2$ & $6.8 \pm 0.0$ & $4.1 \pm 0.06$ \\
\hline & 24 & $6.3 \pm 0.01$ & $8.3^{\mathrm{a}} \pm 0.1$ & $84.3 \pm 0.1$ & $12 \pm 0.0$ & $3.6 \pm 0.0$ \\
\hline \multirow[t]{3}{*}{$\mathrm{HHT}_{120}$} & 0 & $6.73 \pm 0.05$ & -- & -- & -- & -- \\
\hline & 6 & $6.28 \pm 0.03$ & 1.0 & $81.3 \pm 0.9$ & $16.3 \pm 0.1$ & $2.4 \pm 0.02$ \\
\hline & 24 & $6.37 \pm 0.0$ & $16.3^{\mathrm{c}} \pm 0.9$ & $49.1 \pm 1.5$ & $49.1 \pm 0.5$ & $1.8 \pm 0.05$ \\
\hline \multirow[t]{3}{*}{$\mathrm{HHT}_{150}$} & 0 & $6.76 \pm 0.03$ & -- & -- & -- & -- \\
\hline & 6 & $6.28 \pm 0.0$ & $13.3^{\mathrm{b}, \mathrm{c}} \pm 0.3$ & $75.2 \pm 0.4$ & $22.5 \pm 0.3$ & $2.2 \pm 0.09$ \\
\hline & 24 & $6.40 \pm 0.07$ & $16.3^{\mathrm{c}} \pm 0.2$ & $9 \pm 0.8$ & $7 \pm 0.3$ & $0.3 \pm 0.0$ \\
\hline \multirow[t]{3}{*}{ Inulina } & 0 & $6.60 \pm 0.09$ & -- & -- & -- & -- \\
\hline & 6 & $5.80 \pm 0.08$ & $10.1^{\mathrm{b}} \pm 0.2$ & $55.4 \pm 0.2$ & $37.6 \pm 0.2$ & $6.9 \pm 0.1$ \\
\hline & 24 & $6.0 \pm 0.03$ & $29.3^{\mathrm{d}} \pm 0.3$ & $45.0 \pm 0.2$ & $33.8 \pm 0.6$ & $21.2 \pm 0.07$ \\
\hline \multirow[t]{3}{*}{ Pectina } & 0 & $6.52 \pm 0.03$ & -- & - & -- & -- \\
\hline & 6 & $4.75 \pm 0.1$ & $12.3^{\mathrm{b}, \mathrm{c}} \pm 0.3$ & $63.4 \pm 0.1$ & $30.9 \pm 0.3$ & $5.7 \pm 0.02$ \\
\hline & 24 & $4.73 \pm 0.04$ & $35.2^{\mathrm{e}} \pm 0.4$ & $40.6 \pm 0.3$ & $34.4 \pm 0.6$ & $25.0 \pm 0.2$ \\
\hline
\end{tabular}

Tabla A6. pH, contenido de AGCC y proporción molar en la fermentación in vitro de los hidrolizados obtenidos a $90^{\circ} \mathrm{C}$. 


\section{ANEXO G}

En la Tabla A7 aparecen el pH, contenido de AGCC y proporción molar en la fermentación in vitro de los hidrolizados obtenidos a $100^{\circ} \mathrm{C}$.

\begin{tabular}{|c|c|c|c|c|c|c|}
\hline \multirow[b]{2}{*}{ Muestra } & \multirow{2}{*}{$\begin{array}{c}\text { Tiempo } \\
\text { (h) }\end{array}$} & \multirow[b]{2}{*}{ pH } & \multirow{2}{*}{$\begin{array}{c}\text { Ésteres de } \\
\text { ácidos grasos } \\
\text { totales } \\
\left(\text { mmol }^{*} \mathbf{L}^{-1}\right)\end{array}$} & \multicolumn{3}{|c|}{ Proporción molar (\%) } \\
\hline & & & & Acético & Propiónico & Butírico \\
\hline \multirow{3}{*}{$\mathrm{HHT}_{30}$} & 0 & $6.75 \pm 0.07$ & -- & -- & -- & -- \\
\hline & 6 & $6.43 \pm 0.03$ & $13.2^{\mathrm{a}} \pm 0.3$ & $96.0 \pm 0.5$ & $2.0 \pm 0.1$ & $2.0 \pm 0.02$ \\
\hline & 24 & $6.15 \pm 0.01$ & $25.5^{\mathrm{c}} \pm 1.0$ & $90.2 \pm 1.0$ & $4.8 \pm 0.02$ & $4.0 \pm 0.02$ \\
\hline \multirow[t]{3}{*}{$\mathrm{HHT}_{60}$} & 0 & $6.80 \pm 0.0$ & -- & -- & -- & -- \\
\hline & 6 & $6.16 \pm 0.03$ & $11.3^{\mathrm{a}} \pm 1.1$ & $93.0 \pm 0.9$ & $3.6 \pm 0.06$ & $3.4 \pm 0.05$ \\
\hline & 24 & $5.79 \pm 0.01$ & $28.0^{\mathrm{c}, \mathrm{d}} \pm 1.4$ & $92.1 \pm 1.2$ & $4.9 \pm 0.1$ & $3.0 \pm 0.2$ \\
\hline \multirow[t]{3}{*}{$\mathrm{HHT}_{90}$} & 0 & $6.75 \pm 0.07$ & -- & -- & -- & -- \\
\hline & 6 & $6.52 \pm 0.0$ & $13^{\mathrm{a}} \pm 0.2$ & $88.0 \pm 0.2$ & $7.3 \pm 0.06$ & $4.6 \pm 0.2$ \\
\hline & 24 & $5.82 \pm 0.02$ & $26.3^{\mathrm{c}} \pm 1.7$ & $84.1 \pm 0.7$ & $10 \pm 0.3$ & $5.9 \pm 0.1$ \\
\hline \multirow[t]{3}{*}{$\mathrm{HHT}_{120}$} & 0 & $6.6 \pm 0.0$ & -- & -- & -- & -- \\
\hline & 6 & $6.02 \pm 0.01$ & $15.4^{\mathrm{a}, \mathrm{b}} \pm 0.2$ & $80.3 \pm 0.5$ & $16.3 \pm 0.02$ & $3.4 \pm 0.01$ \\
\hline & 24 & $5.87 \pm 0.01$ & $18.9^{\mathrm{b}} \pm 1.0$ & $59.1 \pm 1.0$ & $29.1 \pm 0.3$ & $11.8 \pm 0.03$ \\
\hline \multirow[t]{3}{*}{$\mathrm{HHT}_{150}$} & 0 & $6.7 \pm 0.03$ & -- & -- & -- & -- \\
\hline & 6 & $5.96 \pm 0.02$ & $16.0^{\mathrm{a}} \pm 0.1$ & $77.3 \pm 0.1$ & $20.9 \pm 0.6$ & $1.8 \pm 0.02$ \\
\hline & 24 & $5.74 \pm 0.02$ & $25.8^{\mathrm{c}} \pm 0.5$ & $51.2 \pm 0.5$ & $40.9 \pm 0.3$ & $7.9 \pm 0.02$ \\
\hline \multirow[t]{3}{*}{ Inulina } & 0 & $6.60 \pm 0.09$ & -- & -- & -- & -- \\
\hline & 6 & $5.80 \pm 0.08$ & $10.1^{\mathrm{a}} \pm 0.2$ & $55.4 \pm 0.2$ & $37.6 \pm 0.2$ & $6.9 \pm 0.1$ \\
\hline & 24 & $6.0 \pm 0.03$ & $29.3^{\mathrm{c}, \mathrm{d}} \pm 0.3$ & $45.0 \pm 0.2$ & $33.8 \pm 0.6$ & $21.2 \pm 0.07$ \\
\hline \multirow[t]{3}{*}{ Pectina } & 0 & $6.52 \pm 0.03$ & -- & -- & -- & -- \\
\hline & 6 & $4.75 \pm 0.1$ & $12.3^{\mathrm{a}} \pm 0.3$ & $63.4 \pm 0.1$ & $30.9 \pm 0.3$ & $5.7 \pm 0.02$ \\
\hline & 24 & $4.73 \pm 0.04$ & $35.2^{\mathrm{e}} \pm 0.4$ & $40.6 \pm 0.3$ & $34.4 \pm 0.6$ & $25.0 \pm 0.2$ \\
\hline
\end{tabular}

Tabla A7. pH, contenido de AGCC y proporción molar en la fermentación in vitro de los hidrolizados obtenidos a $100^{\circ} \mathrm{C}$. 


\section{ANEXO H}

En la Tabla A8 aparecen el pH, contenido de AGCC y proporción molar en la fermentación in vitro de los oligosacáridos, del hidrolizado obtenido a $100^{\circ} \mathrm{C}$ por $60 \mathrm{~min}$ y de los controles.

\begin{tabular}{|c|c|c|c|c|c|c|}
\hline \multirow[b]{2}{*}{ Muestra } & \multirow{2}{*}{$\begin{array}{c}\text { Tiempo } \\
\text { (h) }\end{array}$} & \multirow[b]{2}{*}{ pH } & \multirow{2}{*}{$\begin{array}{c}\text { Ésteres de } \\
\text { ácidos grasos } \\
\text { totales } \\
\left(\mathbf{m m o l}^{*} \mathbf{L}^{-1}\right) \\
\end{array}$} & \multicolumn{3}{|c|}{ Proporción molar (\%) } \\
\hline & & & & Acético & Propiónico & Butírico \\
\hline \multirow[t]{3}{*}{ Oligo } & 0 & $6.75 \pm 0.07$ & -- & -- & -- & -- \\
\hline & 6 & $6.43 \pm 0.03$ & $11.4^{\mathrm{b}} \pm 0.2$ & $61.4 \pm 0.7$ & $34.2 \pm 0.3$ & $4.4 \pm 0.2$ \\
\hline & 24 & $6.15 \pm 0.01$ & $31.2^{\mathrm{f}} \pm 1.0$ & $53.5 \pm 1.0$ & $32.0 \pm 0.02$ & $14.4 \pm 0.2$ \\
\hline \multirow[t]{3}{*}{$\mathrm{HHT}_{60}$} & 0 & $6.80 \pm 0.0$ & -- & -- & -- & -- \\
\hline & 6 & $6.16 \pm 0.03$ & $11.3^{\mathrm{b}} \pm 1.1$ & $93.0 \pm 0.9$ & $3.6 \pm 0.06$ & $3.4 \pm 0.05$ \\
\hline & 24 & $5.79 \pm 0.01$ & $28.0^{\mathrm{d}} \pm 1.4$ & $92.1 \pm 1.2$ & $4.9 \pm 0.1$ & $3.0 \pm 0.2$ \\
\hline \multirow[t]{3}{*}{ Inulina } & 0 & $6.60 \pm 0.09$ & -- & -- & -- & -- \\
\hline & 6 & $5.80 \pm 0.08$ & $10.1^{\mathrm{a}} \pm 0.2$ & $55.4 \pm 0.2$ & $37.6 \pm 0.2$ & $6.9 \pm 0.1$ \\
\hline & 24 & $6.0 \pm 0.03$ & $29.3^{\mathrm{e}} \pm 0.3$ & $45.0 \pm 0.2$ & $33.8 \pm 0.6$ & $21.2 \pm 0.07$ \\
\hline \multirow[t]{3}{*}{ Pectina } & 0 & $6.52 \pm 0.03$ & -- & -- & -- & -- \\
\hline & 6 & $4.75 \pm 0.1$ & $12.3^{c} \pm 0.3$ & $63.4 \pm 0.1$ & $30.9 \pm 0.3$ & $5.7 \pm 0.02$ \\
\hline & 24 & $4.73 \pm 0.04$ & $35.2^{\mathrm{g}} \pm 0.4$ & $40.6 \pm 0.3$ & $34.4 \pm 0.6$ & $25.0 \pm 0.2$ \\
\hline
\end{tabular}

Tabla A8. pH, contenido de AGCC y proporción molar en la fermentación in vitro de los oligosacáridos (oligo), del hidrolizado obtenido a $100^{\circ} \mathrm{C}$ y de los controles inulina y pectina.

Los resultados con el promedio de dos experimentos independientes \pm desviación estándar. $\mathrm{a}, \mathrm{b}, \mathrm{c}, \mathrm{d}, \mathrm{e}, \mathrm{f}, \mathrm{g}$ Medias en la misma columna para muestras distintas con diferente letra minúscula son diferentes $(\mathrm{p}<0.05)$. 
El jurado designado por la División de ciencias Biológicas y de la Salud de la Unidad Iztapalapa, aprobó la tesis:

\section{EVALUACIÓN DE LA ACTIVIDAD PREBIÓTICA DE HIDROLIZADOS DEL MATERIAL LIGNOCELULÓSICO DE LA PLANTA DE AMARANTO (Amaranthus hypochondriacus L.).}

Que presenta:

QA. Alex María Daniela Flores Calderón

Comité tutorial:

Director: Dr. Jorge Soriano Santos

Asesor: Dr. José Ramón Verde Calvo

Asesor: Dr. Ezequiel Delgado Fornué

Jurado:

Presidente: Dr. José Ramón Verde Calvo

Secretario: Dr. Héctor Bernardo Escalona Buendía

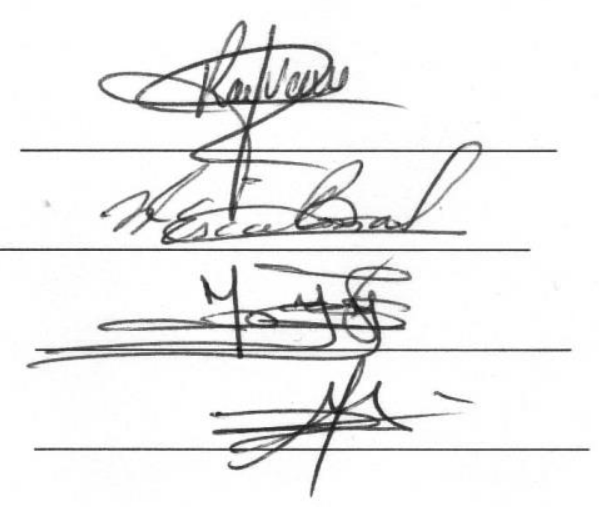

Vocal: Dr. Marcos Meneses Mayo

Vocal: Dr. Gerardo Díaz Godínez 